

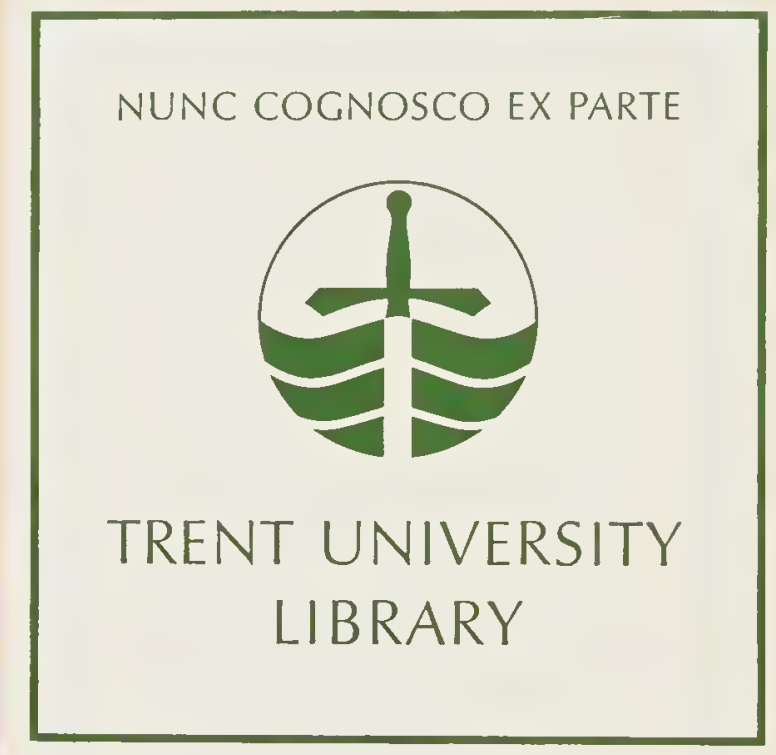

PRESENTED BY

Mrs. H. H. Graham 
Trent University Library 

Digitized by the Internet Archive in 2019 with funding from Kahle/Austin Foundation 
. 



\section{F E R N S:}

\section{BRITISH AND EXOTIC.}

VOL U ME VI.

Containing

O NOCLEA.

F A D Y E N I A.

C Y C L O P E L T IS.

D I D Y M O C H L $A$ N $A$.

ASPIDIU M, IN PART.

BY

E. J. LOWE, ESQ., F.R.A.S., F.G.S., F.L.S., F.Z.S., F.M.S.,

Hon. Mem. Dublin Nat. Ilist. Soc., Mem. Geolog. Soc., Edin., Corr. Mem. Lyceum

Nat. Hist., New York, Corr. Mem. Manchester Lit. and Phil. Soc., etc.

Author of a "Natural IIistory of British and Exotic Ferns," "British Cirasses," etc, etc.

LON DON:

GROOMBRIDGE AND SONS, 5, PATERNOSTER ROW. MI DCCC LXVII. 
QK523. L9 V.6 


\section{CONTENTS OF VOL. VI.}

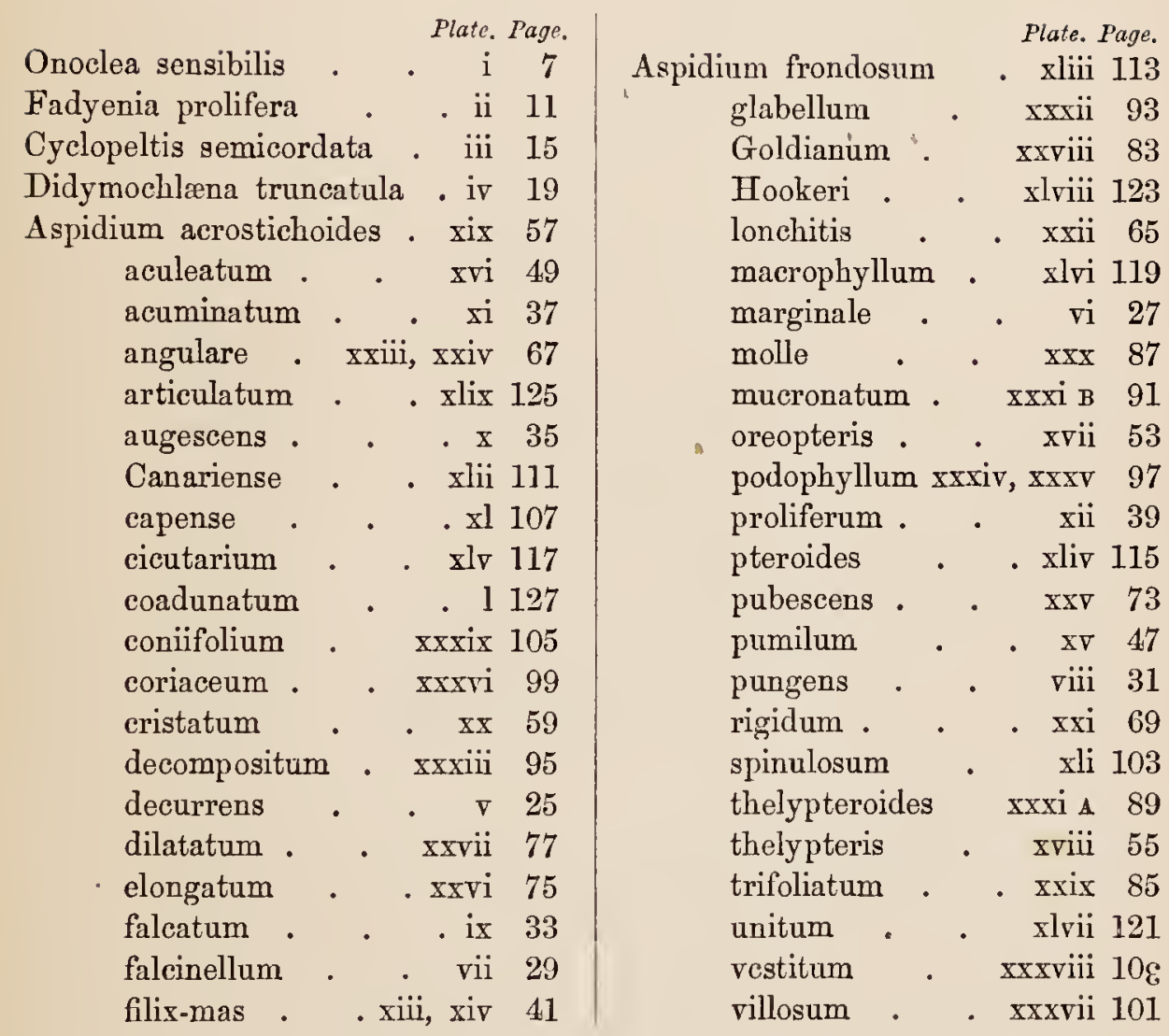





\section{F E R N S;}

\section{BRITISH AND EXOTIC.}

\section{ASPIDIE A. J. Sмiтh.}

Is many instances the only difference between Polypodiere and Aspidiece is confined to the former having no indusium, whilst the latter is furnished with an indusium; this, however, is sometimes very small, and at others so soon detached from the sori, that fronds must be examined, the one with a microscope and the other at an early stage, in order that the difference from Polypodiece may be detected.

Mr. Smith remarks that there are above two hundred described species of Aspidiea.

Aspidiece is distinguished from Aspleniece mostly by having circular instead of lateral sori, and when the sori are lateral they are attached across the venule, instead of longitudinally in the direction of the venules as in Aspleniea.

Sori circular, with one or two exceptions, where oblong. They are intramarginal, and have a special indusium, which is either orbicular, produced from the centre, (central,) or reniform or cucullate, produced from the interior side of the sporangiferous receptacle, (lateral,) or occasionally attached all round the receptacle, and including the sporangia, (calyciform.)

Mostly moderate-sized Ferns.

VOL. VI. 
Mr. Smith, in his Catalogue of the Ferns of $\mathrm{Kew}$, divides the cultivated species into the following families:-

1.-Hypoderris, one species.

2.-Aspidium, seven species.

3.-Onoclea, one species.

4.-Cyclodium, one species.

5.-Fadyenia, one species.

6.-Nephrodium, seven species.

7.-Woodsia, four species.

8.-Cystopteris, five species.

9.-Lastrea, twenty-nine species.

10.-Polystichum, fourteen species.

11.-Cyclopeltis, one species.

12.-Nephrolepis, seven species.

13.-Didymochlana, one species.

14.-Arthropteris, two species.

15.-Oleandra, two species.

Kunze, in his "Index Filicum," collects most of the above under the head Aspidium, preferring to give them in sections; he only recognises Nephrodium, Lastrea, Polystichum, Bathmium, and Sagenia as groups in Aspidium, whilst Cyclopeltis, Fadyenia, Nephrolepis, Oleandra, Cystopteris, Didymochlcena, etc., he separates from Aspidium, yet his Catalogue of the tribe Aspidium numbers above one hundred species.

Moore and Houlston, in their "Genera and Species of Cultivated Ferns," divide Aspidiece as follows:-

1.-Hypoderris, one species.

2.-Aspidium, two species.

3.-Sagenia, four species.

4.-Onoclea, one species.

5.-Cyrtomium, one species.

6.-Fadyenia, one species.

7.-Nephrodium, six species.

8.-Woodsia, four species.

9.-Cystopteris, seven species.

10.-Lastrea, thirty-one species.

11.-Polystichum, fifteen species.

12.-Cyclopeltis, one species.: 
13.-Didymochlcena, one species.

14.-Nephrolepis, seven species.

15.-Oleandra, two species.

Fee, in his "Grenres de la Famille des Polypodiacées," enumerates many more species. He does not place them all under Aspidiea, but groups them under three heads, Cyclodiea, Aspidiea, and Nephrolepidea.

1st. In Cyclodiere he arranges the following:-

1.-Polystichum, forty-six species.

2.-Phanerophlebia, two species.

3.-Hemicardion, four species.

4.-Amblia, one species.

5.-Cyclodium, three species.

6.-Cyrtomium, two species.

7.-Podopeltis, one species.

8.-Bathmium, ten species.

2nd. In Aspidiere the following:-

1.-Aspidium, about seventy species.

2.-Cystopteris, fourteen species.

3.-Lepidonevron, twelve species.

4.-Dichasium, two species.

5.-Oleandra, twelve species.

6.-Nephrodium, about forty species.

7.-Haplodictyon, two species.

8.-Abacopteris, five species.

9.-Pleocnemia, three species.

10.-Sagenia, seven species.

11.-Phlebiogonium, one species.

12.-Cardiochlana, eleven species.

13.-Fadyenia, one species.

3rd. In Nephrolepidea the following:-

1.-Nephrolepis, seven species.

2.-Pteronevron, one species.

3.- Saccoloma, three species.

4.-Pachypleuria, five species.

5.-Humata, two species.

Thus Fee enumerates above two hundred and fifty species, 
yet many of these have not hitherto been cultivated in this country, and others are placed by different authors in other families.

Presl, in his "Tantamen Pteridographix," places under Aspidiacece the following:-

1.-Lastrea, seventy-seven speeies.

2.-Oleandra, four species.

3.-Nephrolepis, twenty-four species.

4.-Nephrodium, twenty-four species.

5.-Polystichum, fifty species.

6.-Phanerophlelia, one species.

7.-Cyclodium, three species.

8.-Cyrtomium, two species.

9.--Sagenia, six species.

10.-Aspidium, eleven species.

11.-Didymochlana, one species.

In all about two hundred species. 


\section{GENUS I.}

\section{ONOCLEA. LINNAUS.}

BARrex and fertile fronds different. The fertile frouds being contracted, the segments rugose, sessile, bacciform, somcwhat oblong; margin conniving, fimbriate, and menbranous, forming a universal indusium.

Sori circular, confluent; each segment consisting of from four to eight. Spore-cases medial, with concrete pedicels. Special indusium very membranous, lateral and cucullate. Fronds pinnate and bipinnate; length from one to two feet.

Rhizoma creeping.

Fertile veins simple, direct, and frce. Sterile veins reticulated. The pinnules of the fertile fronds roll up so as to completely hide the sori.

Two species alone are described, and only one is in cultivation, although both have been said to be introduced.

The name is derived from the Greek, and refers to thc manner of the folding-up of the fertile segments. 





Portion of Pinna of barren Frond.

\section{ONOCLEA SENSIBILIS.}

Linneus. Smith. Moore and Houlston. Kunze. Link. Schkuhr. Kaulfuss. Presl. Fee. Sprengel.

PLATE I. VOL. VI.

\author{
Onoclea obtusiloba, \\ "r obtusilobata, \\ Rhagiopteris obtusiloba,
}

Onoclea-To close a vessel; (from the Greek.)
LiNk.

Sспкинв.

Sensibilis-Sensitive.

A NoBle species long known to Fern growers, and a very desirable addition to our hardy fernery, being exceedingly distinct from all others. Michaux, Sprengel, and other botanists have described two species, the second under the name of Onoclea obtusiloba. It seems doubtful whether there are really two species, situation probably causing the difference in the size and form of the frond. The specimens which $\mathrm{I}$ have seen as $O$. obtusiloba have all eventually put on the characters of O. sensibitis when grown side by side.
A hardy deciduous species. 
Native of North Amcrica, Florida, and the variety O. obtusiloba in Pennsylvania.

Was known in England as early as 1699, and at $K$ ew in 1793.

Barren and fertile fronds different.

Barren fronds triangular in form, glabrous, pinnate; the pinnæ oblong-lanccolate in form, sinuately pinnatifid, the superior ones being decurrent at the base. Segments oblong-obtuse; margin entire.

Fertile frond contracted, not quite as long as the barren frond, bipinnate; pinnules rugose, sessile, consisting of from twelve to twenty on each pinna. The contractions of the segments form a unilateral raceme, oblong, ovate, and bacciform, concealing the sori.

Fronds laterai, adhering to a creeping rhizoma. Length from one to two feet; colour pale green.

Veins of fertile frond simple, direct, and free; in the barren frond reticulated.

For plants of this species I am indebted to Sir Oswald Mosley, Bart., of Rolleston Hall.

It may be procured of Messrs. Rollisson, of Tooting; Sim, of Foot's Cray; Kennedy, of Covent Garden; Masters, of Canterbury; Veitch, Jun., of Chelsea; A. Henderson, of Pineapple Place; Cutbush, of Highgate; Young, of Taunton; Bass and Brown, Sudbury; Stansfield, of Todmorden; and Cooling, of Derby.

The illustrations are barren and fertile fronds, from a plant in my own collection. 


\section{GENUS II.}

\section{FADYENIA. HoOKER.}

BARREN and fertile fronds different.

Fertile fronds contracted; both simple.

Veins forked; venules anastomosing and reticulate.

Sori oblong-reniform, transversely uniserial; formed on the upper portion of a veinlet in the costal areoles.

Indusium exceedingly large, lateral and oblong-reniform.

A solitary species, of dwarf habit.

The name is in reference to the late Dr. M' Fadyen.

VOL. VI. 



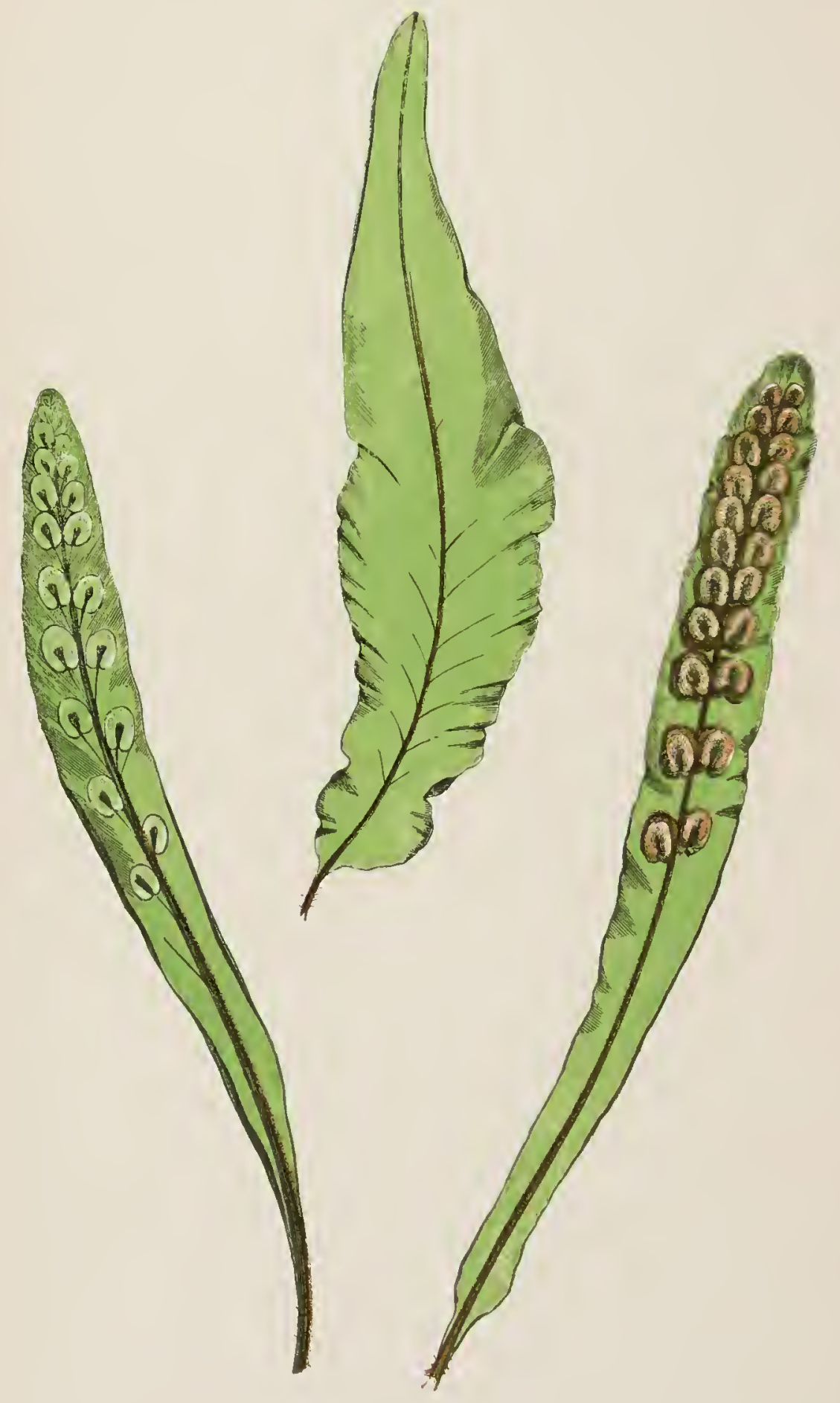

FADYEIA PROLIFLKA.
II-VOL. 6. 

A MORE singular than beautiful Fern, requiring moisture and shade to grow successfully. It is a difficult species to manage, although when it does flourish it spreads itself in all directions, from the rooting of the proliferous apices of the barren fronds.

A stove evergreen species.

Native of Jamaica and the Island of Cuba.

It was introduced into the Royal Gardens, Kew, in the year 1842, having been sent there by Mr. W. Purdie.

Fertile frond simple, glabrous, upright, lanceolate in form, narrowing towards the base; apex broad and rounded.

Barren frond horizontal, oblong-ovate, elongate, tapering to the apex, where it is proliferous.

Fronds terminal, adherent to a small tufted rhizoma.

Sori large, reniform, near the apex imbricate.

Indusium hairy; margin somewhat dentate.

Length of barren frond five inches, fertile frond four inches; colour dull green.

For plants my thanks are due to Mr. J. Henderson, of Wentworth; and to Messrs. Booth, of Hamburg.

Plants may be procured of Messrs. Sim, of Foot's Cray; Rollisson, of Tooting; Kennedy, of Covent Garden; Masters, of Canterbury; Booth, of Hamburg; Veitch, Jun., of Chelsea; Stansfield, of Todmorden; Cutbush, of Highgate; and A. Henderson, of Pine-apple Place.

The illustration is from fronds forwarded by Mr. J. Henderson, of Wentworth. 


\section{GENUS III.}

\section{CYCLOPELTiS. J. Sмith.}

Froxds pinnate, glabrous, and articulated with the rachis. Veins dichotomously branched; venules direct, free, the anterior and exterior one of each fascicle soriferous.

Sori circular, biserial, medial or terminal.

Indusium orbicular and peltate.

A solitary species.

The name, derived from the Greek, has reference to the indusium, and means a small round buckler.

A tropical Fern. 




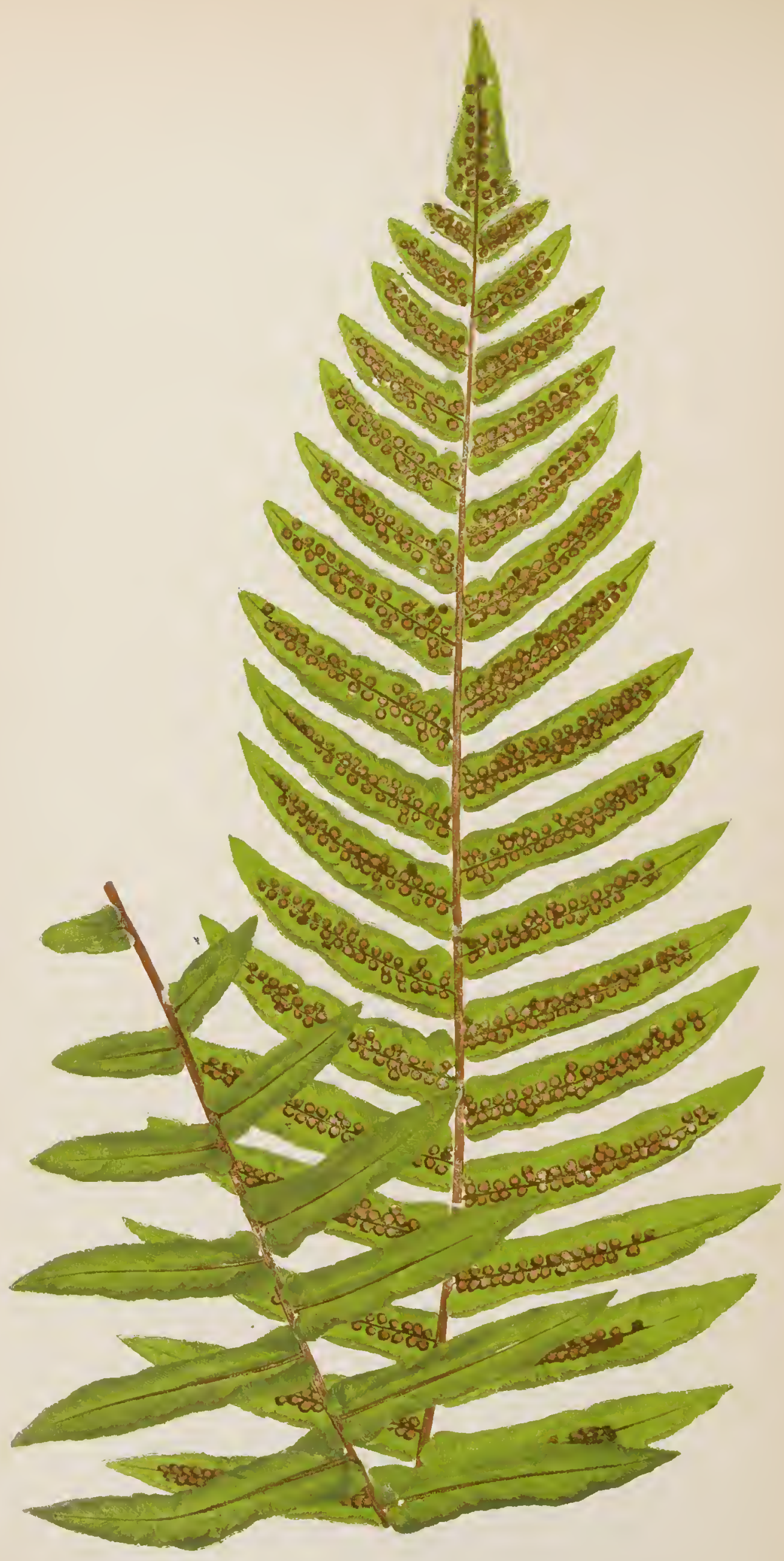






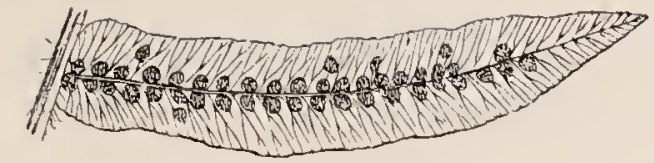

Pinna of mature Frond, under side.

\section{CYCLOPELTIS SEMICORDA'TA.}

\section{J. Silith. Moore and Houlston. Kunze.}

PLATE III. VOL. VI.

Aspidium semicordatum, Lastrea semicordata, Phanerophlebia nephrolepis, Polypodium caducum,

Cyclopeltis-A small round buckler.
Swartz. Plumier. Sprexgel. Presl.

TiEe.

Huмвоцрт. (?)

Ax interesting yet uncommon cultivated species, only to be met with in large collections.

An evergreen stove Fern.

Native of the American Meridian, the West Indies, Mexico, Jamaica, and the Philippine Islands.

Introduced into the Royal Gardens, Kew, in 1844, having been received from Mr. N. Wilson.

Fronds lanceolate, pinnate, the pinnæ being glabrous, falcatelanceolate, sessile; from four to five inches in length; irregularly auriculate at the base, and articulated with the rachis.

Fronds terminal, adherent to a short, stout, somewhat tufted rhizoma, which is scaly.

Rachis pubescent.

Sori circular, medial, biscrial. Indusium peltate.

Length of frond from two to three feet; colour bright shining green. 
For a plant of this species I am indebted to Mr. J. Henderson, of Wentworth.

It is not in any of the Nurserymen's Catalogues.

The illustration is from a portion of a frond forwarded by Mr. Henderson, of Wentworth. 


\section{GENUS IV.}

\section{DiDYMochlena. Desvaux.}

Fronds bipinnate. Caudex erect and arborescent, attaining a height of above two feet, and bearing from its crown large fronds, from three to five feet in length.

Veins forked and radiating; venules direct, free, the exterior one fertile.

Sori elliptical, uniserial, and situated on the apex of a venule. Indusium oblong, attached along the centre longitudinally. A solitary Exotic species.

Named from the Greek, in reference to the indusium being double. 



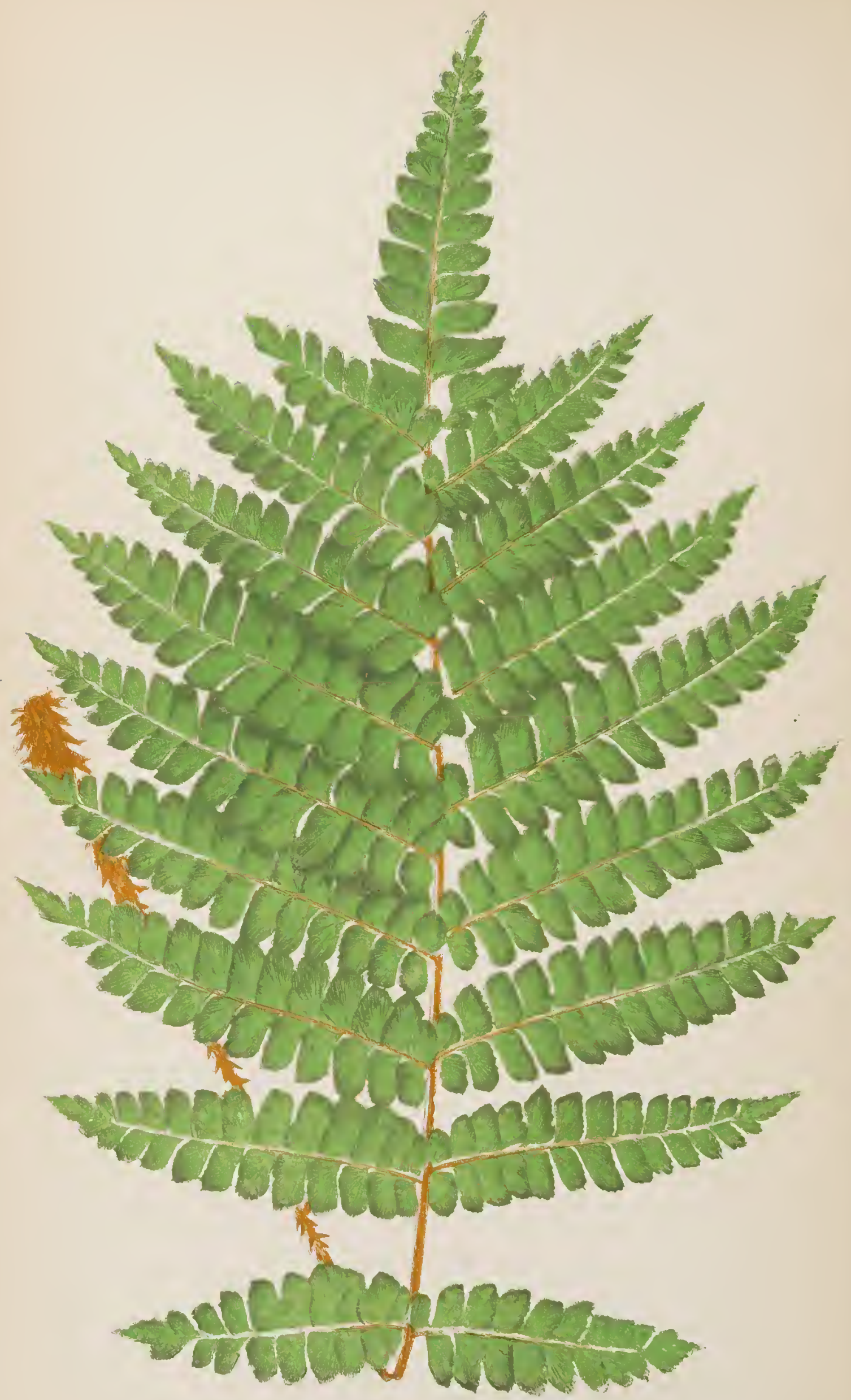






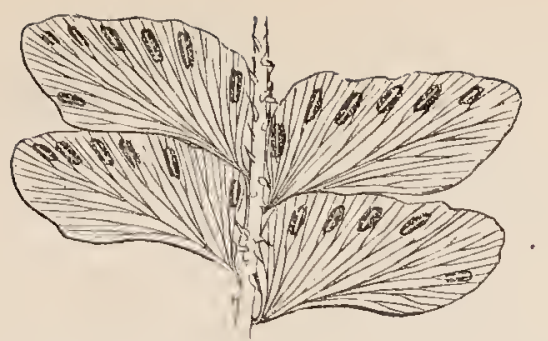

Portion of mature Frond, under side.

\section{DIDYMOCHLANA TRUNCATULA.}

\section{J. Simth. Moore and Houlston. Schott, MS.}

PLATE IV. VOL. VI.

Didymochlcena sinuosa,

\begin{tabular}{ll} 
" & \multicolumn{1}{c}{ " } \\
" & squamata, \\
" & lunulata,
\end{tabular}

Aspidium truncatulum,

" squamatum,

" cultratum,

" pulcherrimum,

" squamosum,

" truncatum,

" lunulatum,

Adiantum lunulatum,

" fruticosum, Asplenium ramosum, Tegularia adiantifolia, Diplazium pulcherrimum,
Desvaux. Kaulfuss. Sprengel. Link. Presl. Fee. Martens. Schott, MS.

Desvaux.

Of Gardens.

Destaux. Kunze.

Swartz.

Willdenow.

PRESL.

Of Gardens.

Willdenow.

WILLDENOW.

Houttuyn.

Houttuyn, (not of Burmann, Sprengel, Willdenow, Presi, Swartz, Moore

\& Houlston, Hooker \& Greville, WaLitCh, FeE, RetziUs, or RHEEd.)

ARRAB.

Poiret.

- Reinwardt.

RAdDI.

Didymochlona-A double cloak.

T'runcatula-.........?

A charming Exotic species, with somewhat pendulous, handsome, dark green fronds.

An evergreen stove Fern.

Native of Asia, tropics of America, South America, West 
Indies, Brazil, Malayan Islands, Mispaniola, the Island of St. Domingo, Java, and the Philippine Islands.

Received into the Royal Gardens, $\mathrm{Kew}$, in 1828, from Messrs. Loddiges, of Hackney.

Fronds bipinnate, broadly lanceolate; the pinnæ being linearlanceolate, eight to ten inches long, sessile; pinnules sub-rhomboidal, oblong-obtuse, coriaceous, imbricate, truncate-dimidiate at the base; margin slightly crenulate; articulate with the rachis.

Stipes, rachis, and midrib of pinnæ densely clothed with ferruginous tomentum and long, narrow, brown scales.

Fronds terminal, adherent to an arborescent caudex.

Veins forked, radiating; venules direct, free, the exterior one being fertile.

Sori elliptical, uniserial, placed on the apex of a venule. Indusium oblong, longitudinally attached along the centre.

Length of frond from three to five feet; colour rich bright dark green.

Didymochlana sinuosa of Schott has been placed with the present species, still, if only a variety, it is very distinct, the pinnules are usually only half the size of $D$. truncatula, making the branches seem farther apart; indeed in D. truncatula the pinnules of the one branch touch those of the next, whilst in $D$. sinuosa thcy are from half an inch to an inch apart. Then in $D$. truncatula the pinnules are arranged almost at right angles to the branches, whilst in $D$. sinuosa they are at an angle of from $20^{\circ}$ to $45^{\circ}$. In $D$. truncatula the terminal pinnule is elongated and deeply cut, whilst in $D$. sinuosa it is not so much elongated, usually not cut, and more nearly resembles the character of the other pinnules. I fear thesc characters will not prove constant in cultivation.

For plants of D. truncatula I am indebted to M. Schott, Dircctor of the Imperial Gardens of Schonbrünn, near Vienna; and to Messrs. E. G. Henderson, of the Wellington Nursery, St. John's Wood.

It is in the Catalogues of Messrs. Sim, of Foot's Cray; Rollisson, of 'looting; Veitch, Jun., of Chelsea; E. G. Henderson, of St. John's Wood; A. Henderson, of Pine-apple Place; Booth, of Hamburg; W. Cutbush and Sons, of Highgate; Kennedy, of Covent Garden; and Cooling, of Derby.

The illustration is from a plant in my own collection. 


\section{GENUS V.}

\section{A S P I D I U M.}

The distinctive differences between the several divisions may be briefly given as follows:-

\section{ASPIDIUM. Swartz.}

Veiss costrform; venules compoundly anastomosing, from the sides of which free veinlets extend, which end within the areoles.

Sporangia formed on the angles or points of confluence of the veinlets.

Sori circular, in a row on either side of the veins or primary anastomosing venules.

Indusium mostly orbicular and central, although instances occur with it reniform.

Fronds simple, lobed, pinnate, or bipinnate; margin entire, sinuated, or laciniated.

\section{SAGENIA. Prest.}

Veins forked; venules acutely and angularly anastomosing, forming unequal areoles.

Sporangia situated on the angles or points of confluence of the veinlets, or on the apex of a free veinlet.

Sori circular, in a row on either side of the ultimate midrib, or irregular.

Indusium orbicular or reniform.

Fronds pinnate or bipinnate: pinnæ lobed or sinuouslypinnatifid.

Distinguished from Aspidium by the absence of the irregular free veinlets.

Cyrtomium. Presl.

VeIns pinnate; the lower exterior venule free and fertile, 
the others anastomosing angularly, and forming on their exterior sides or angular junctions excurrent fertile free veinlets.

Sporangia medial.

Sori circular, transversely-multiserial, abundant.

Indusium orbicular, central.

Fronds pinnate.

Distinguished from Polystichum in the anastomosing venules. Habit and texture very similar to Polystichum.

The venation of Cyrtomium and the position of its sori is nearly similar to the section Goniophlebium and Cyrtophlebium in Polypodium. Distinguished by having an indusium.

\section{NEPHRODIUM. Schotr.}

Verss pinnate, costæform, the lowest pair or pairs of venules fertile, and angularly anastomosing; their points of meeting combined by an excurrent anastomosing sterile veinlet.

Sporangia medial.

Sori circular, a row on either side of the veins.

Indusium mostly reniform, rarely orbicular.

Fronds simple or pinnate; pinnæ entire, serrate, or sinuouslypinnatifid.

Distinguished by the anastomosing renules.

Nephrodium in venation is similar to the section Goniopteris in Polypodium, and only distinguished by having an indusium.

\section{LASTREA. BORY.}

VEINs pinnate, forked, or costæform; venules direct and free. Sporangia medial or terminal.

Sori circular.

Indusium lateral, reniform, smooth or pilose.

Fronds varying from pinnate to decompound.

Only distinguished from the true form of Polypodium by the presence of an indusium, being similar in habit and venation. 'Those with bipinnatifid fronds only distinguishable from Nephrodium by not having anastomosing venules.

\section{POLYSTICHUM. Roth.}

VEIss pinnately-forked; venules direct and free, the lower exterior one or more, fertile. 
Sporangia usually medial, rarely terminal.

Sori circular.

Indusium orbicular and central, seldom eccentric and reniform.

Fronds simple, pinnate, or bitripinnate; the serrate edges of the frond rigidly spinulose.

Distinguished from Lastrea by the rigid spinulose habit.

Aspidium, Sagenia, Cyrtomium, Nephrodium, Lastrea, and Polystichum run into each other so closely, that it seems advisable to follow Kunze in calling them mere sections of one genus. Were I to separate any of them, it would be done with regard to the habit of the plant alone, and in this case I would place Cyrtomium among the Polystichums. In the most restricted form of Aspidium the habit and general appearance is also distinct from Lastrea, still I have adopted the views of Kunze and retained it.

Onochlea, with its two forms of fronds; Fadyenia, with its two forms of fronds and proliferous habit; Woodsia, a group of small slender Ferns, with peculiar indusium. The genus Cystopteris, another group of small delicate Ferns; Didymochlena, with its several very distinct characters, hereafter to be mentioned; Nephrolepis, with its distinct habit, and having the petiole articulated with the rachis, giving it a power of throwing off its pinnæ freely; and Oleandra; are all to me sufficiently distinct to keep them separated from the genus Aspidium.

We have British examples of both Lastrea and Polystichum.

In Lastrea we have:-

$\begin{array}{lll}\text { Cristata } & \text { Oreopteris } & \text { Thelypteris } \\ \text { Filix-mas } & \text { Rigida } & \text { Multiflora } \\ \text { Recurva } & \text { Spinulosa } & \text { Dilatata }\end{array}$

In Polystichum we have:-
Aculeatum
Angulare
Lonchitis

Aspidium filix-mas, $A$. aculeatum, and $A$. angulare vary so much from spores, that it is difficult to recognise the departure from the normal form as mere varieties; however these will be more closely spoken of when describing the species. 



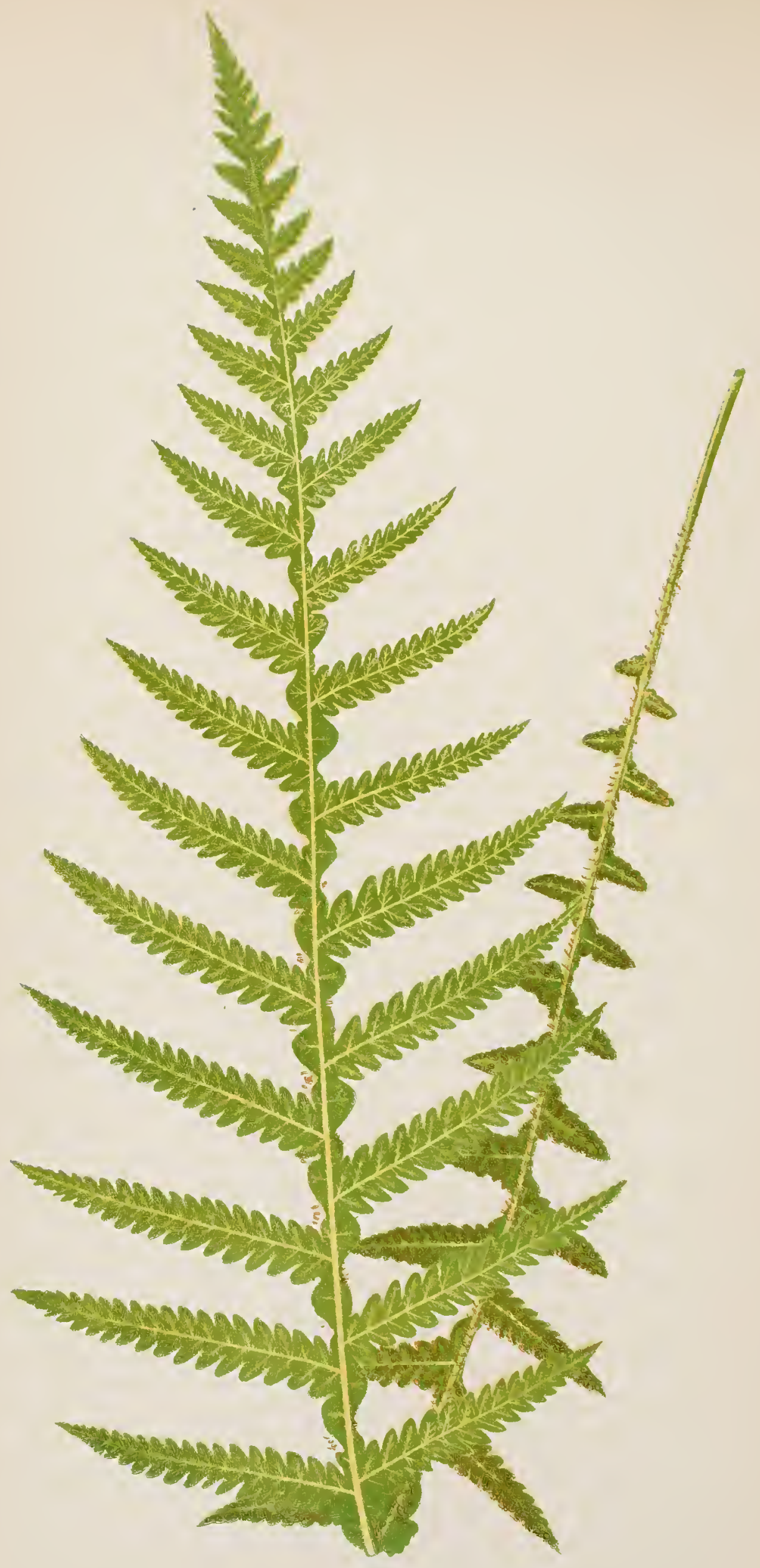

ASPIDIUM DECURRENS.

V-VoL. 6. 



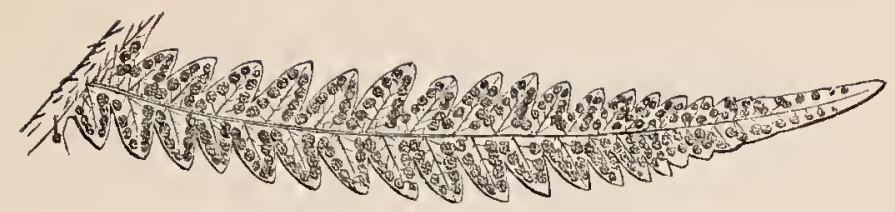

Pinna of mature Frond, under side.

\title{
ASPIDIUM DECURRENS.
}

LOWE.

\author{
PLATE V. VOL. VI.
}

Aspidium decursive-pinnatum, Lastrea decurrens,

" decursive-pinnata,

Polypodium decursive-pinnatum,

Plegopteris decursive-pinnatum,

Aspidium-The Shield Fern.
KUNZE.

J. Smith. Moore \& Houlston. OF Gardens.

Of Gardens.

FEE.

\section{In the Section Lastrea of Authors.}

A PRETTY, rather dwarf, upright-growing Fern.

Mostly considered greenhouse or half-hardy, and deciduous. Plants exposed to last winter's frost have not been injured; it may therefore be said to be hardy.

Native of China.

Received at the Royal Gardens, Kew, from Mr. D. Cameron, in the year 1841.

Fronds lanceolate in shape, pinnate, pinnæ sessilc, pinnatifid, decurrent and lobed, forming a sinuous wing to the rachis; lower ones entire and diminutive. Terminal, adherent to a decumbent slightly-tufted rhizoma.

Sori terminal, or subterminal; indusium small, and speedily becoming obsolete.

Stipes and rachis paleaccous.

VOL. VI. 
Equally well known in gardens as Lastrea decurrens and as L. decursive-pinnata.

Length of frond twelve to fifteen inches; colour pale green. The scales of this Fern are interesting as microscopic objects; they are surrounded with spines having a knob at the apex, and are pellucid.

For plants of this Fern I am indebted to Mr. Henderson, of Wentworth; Messrs. Rollisson, of 'Tooting; and Masters, of Canterbury; and for fronds to Mr. Norman, of Hull, and Messrs. A. Henderson, of Pine-apple Place.

It is in the Catalogues of Messrs. Sim, of Foot's Cray; Kennedy, of Covent Garden; Masters, of Canterbury; Veitch, Jun., of Chelsea; Stansfield, of Todmorden; Cooling, of Derby; Cuthbert, of Highgate; and Young, of Taunton.

The illustration is from a plant in my own collection. 
$\checkmark$ 


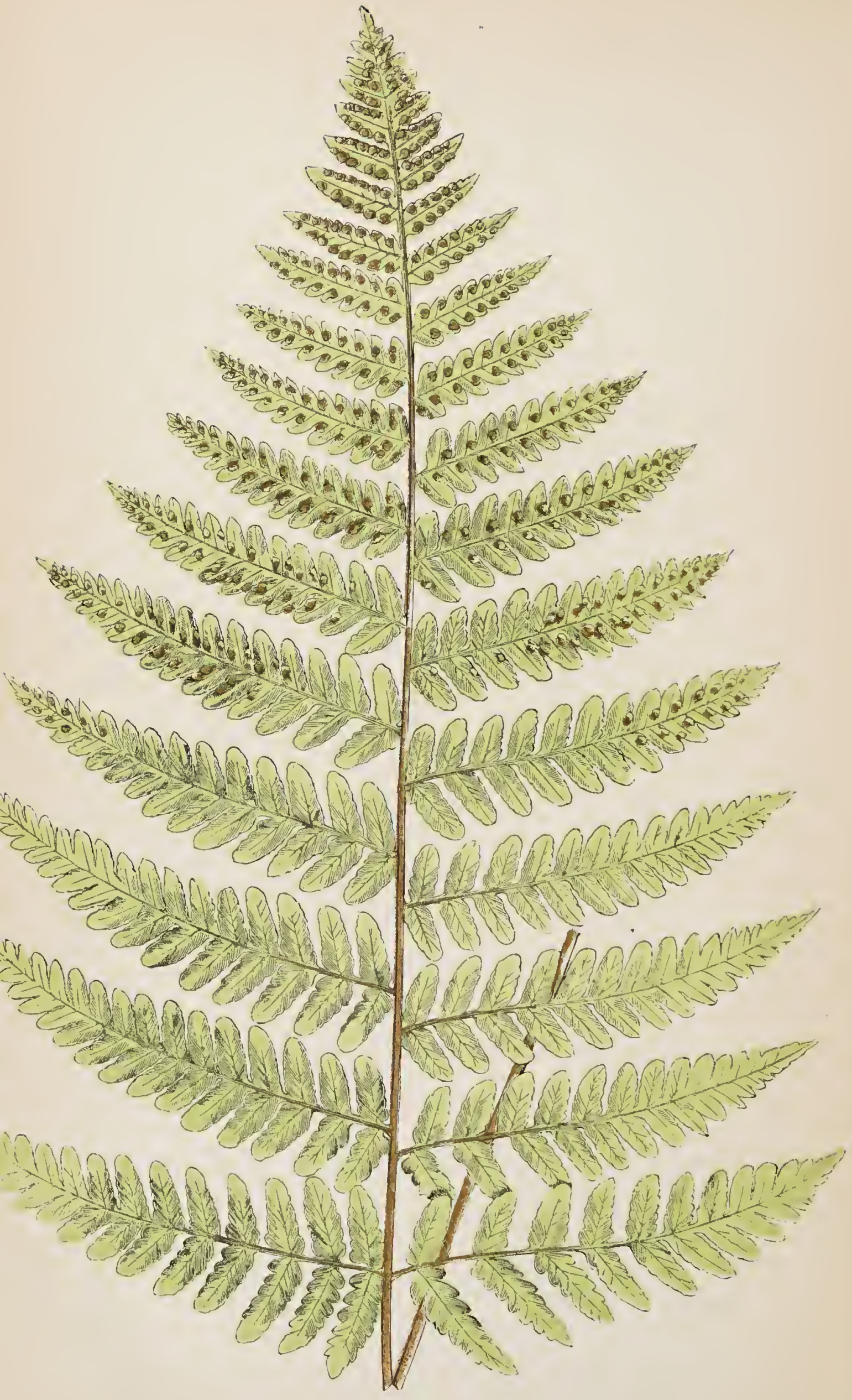





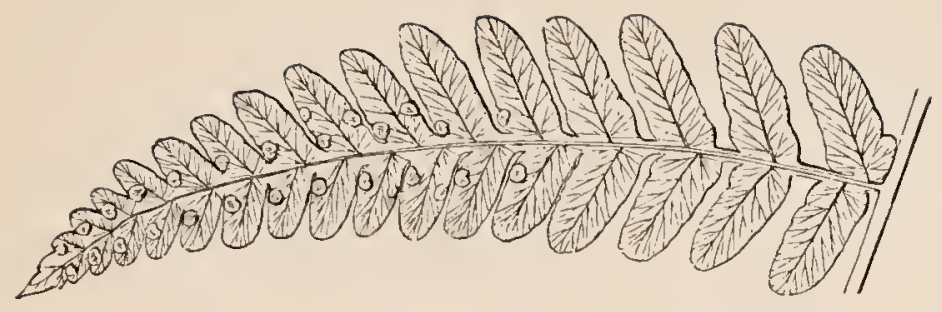

Portion of mature Frond, upper side.

\section{ASPIDIUN MARGINALE.}

Siwartz. Kunze. Link. Willdenow. Sprengel. Fee.

PLATE VI. VOI., VI.

Lastrea maryinalis,

Nephrodium marginale, Polypodium marginale,

Aspidium-The Shield Fern.
Prest. Moore \& Houlston. Smith. Michaux.

LinNaUs.

IN the Section Lastrea of Authors.

As attractive Fern, with sori arranged along the edge of the frond, covered with a pure white indusium.

A deciduous hardy Fern.

Native of North America-Canada and Carolina.

Introduced into the Royal Gardens, Kew, in 1712.

Fronds lanceolate, bipinnate, pinnæ oblong-acuminate in form, pinnules oblong-ovate, obtuse, crenate on the edge, and largest nearest the rachis. Fronds terminal, adherent to a tufted rhizoma, forming large crowns.

Rachis and stipes paleaceous.

Sori marginal.

For plants of this species I am indebted to Mr. R. Sim, of Foot's Cray; and for fronds to Mr. Norman, of Hull. 
It is in the Catalogues of Messrs. Sim, of Foot's Cray; Rollisson, of Tooting; Kennedy, of Covent Garden; A. Henderson, of Pine-apple Place; Cutbush, of Highgate; and Young, of Taunton.

The illustration is from a plant in my own collection. 


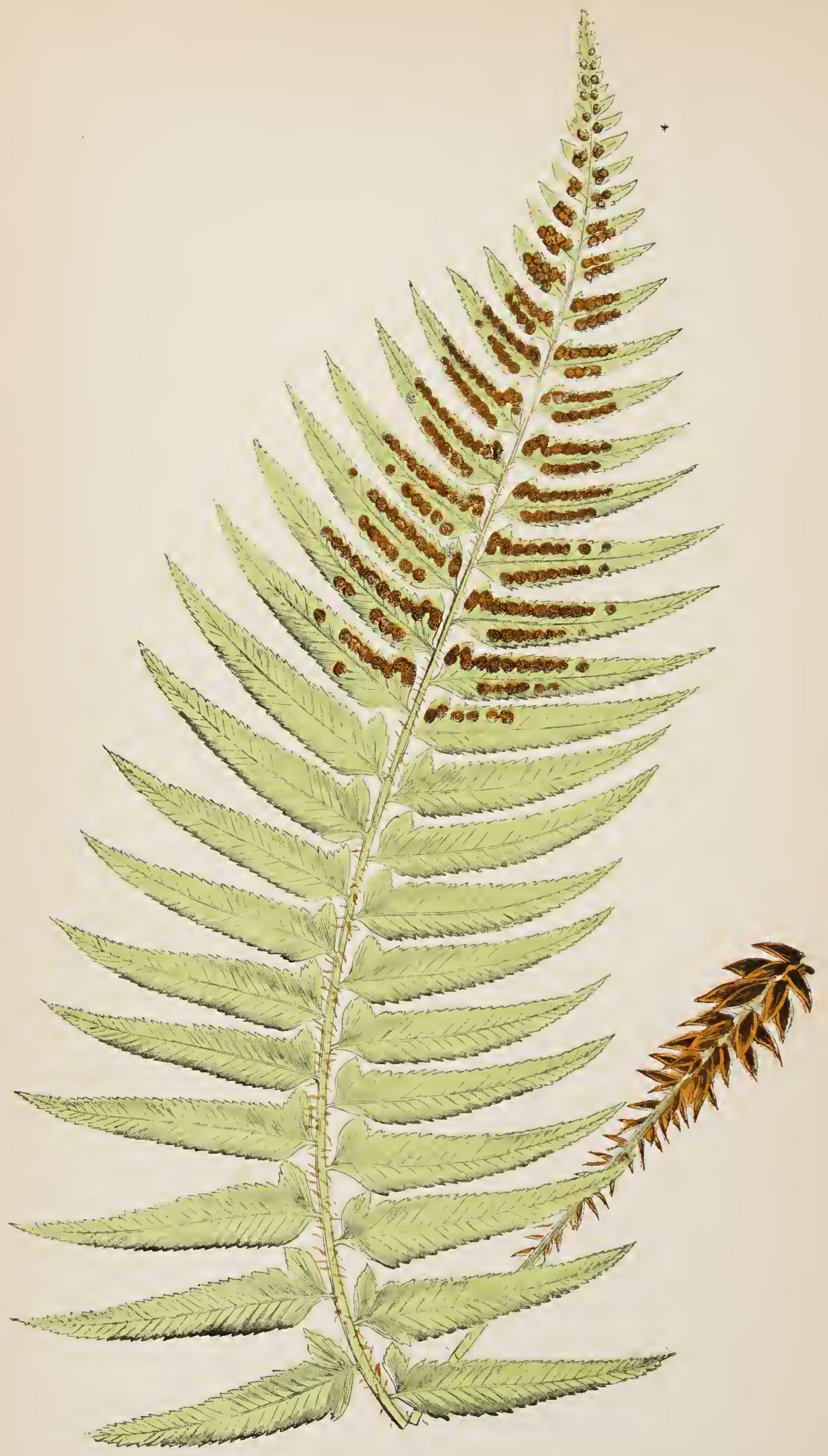






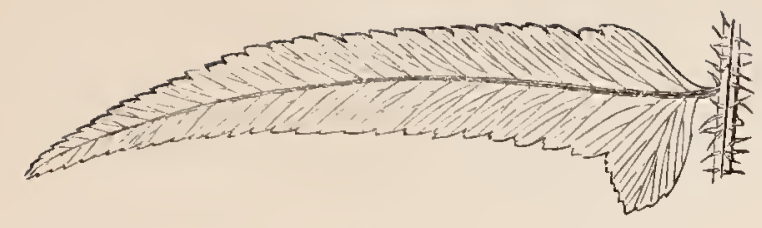

Pinna of mature Frond, upper side.

\section{ASPIDIUM FALCINELLUM.}

Swartz. Kunze.

PLATE VII. VOI. VI.

Aspidium auriculatum, Polystichum falcinellum,
Of Gardens. (Not of Swartz.)

Presc. Moore \& Houlston. Smith.

Aspidium-The Shield Fern. Falcinellum-Small sickle.

In the Section Polystichum of Authors.

ONE of the most attractive Ferns in the section Polystichum, the large bold sori, and the pretty and conspicuous indusium, place this Fern in high estimation among the growers of ornamental plants.

An evergreen greenhouse Fern.

From the Island of Madeira.

Cultivated in the Royal Gardens, Kew, in 1820.

Fronds oblong-lanceolate in form; pinnate, the pinnæ being linear-oblong, petiolate, acute; superior base auriculate, inferior base obliquely truncate, the edges of the frond doubly serrate. Fronds terminal; adherent to a fasciculate tufted rhizoma.

Length from twelve to eighteen inches; colour bright green.

For plants of this species I am indebted to Mr. R. Sim, of Foot's Cray, Kent; and for fronds to Mr. R. Grey, of St. 'Thomas', Exeter, and to Mr. Norman, of Hull. 
It is in the Catalogues of Messrs. A. Henderson, of Pineapple Place; Rollisson, of Tooting; Sim, of Foot's Cray; and Veitch, Jun., of Chelsea.

The illustration is from a plant in my own collection. 
, , , 


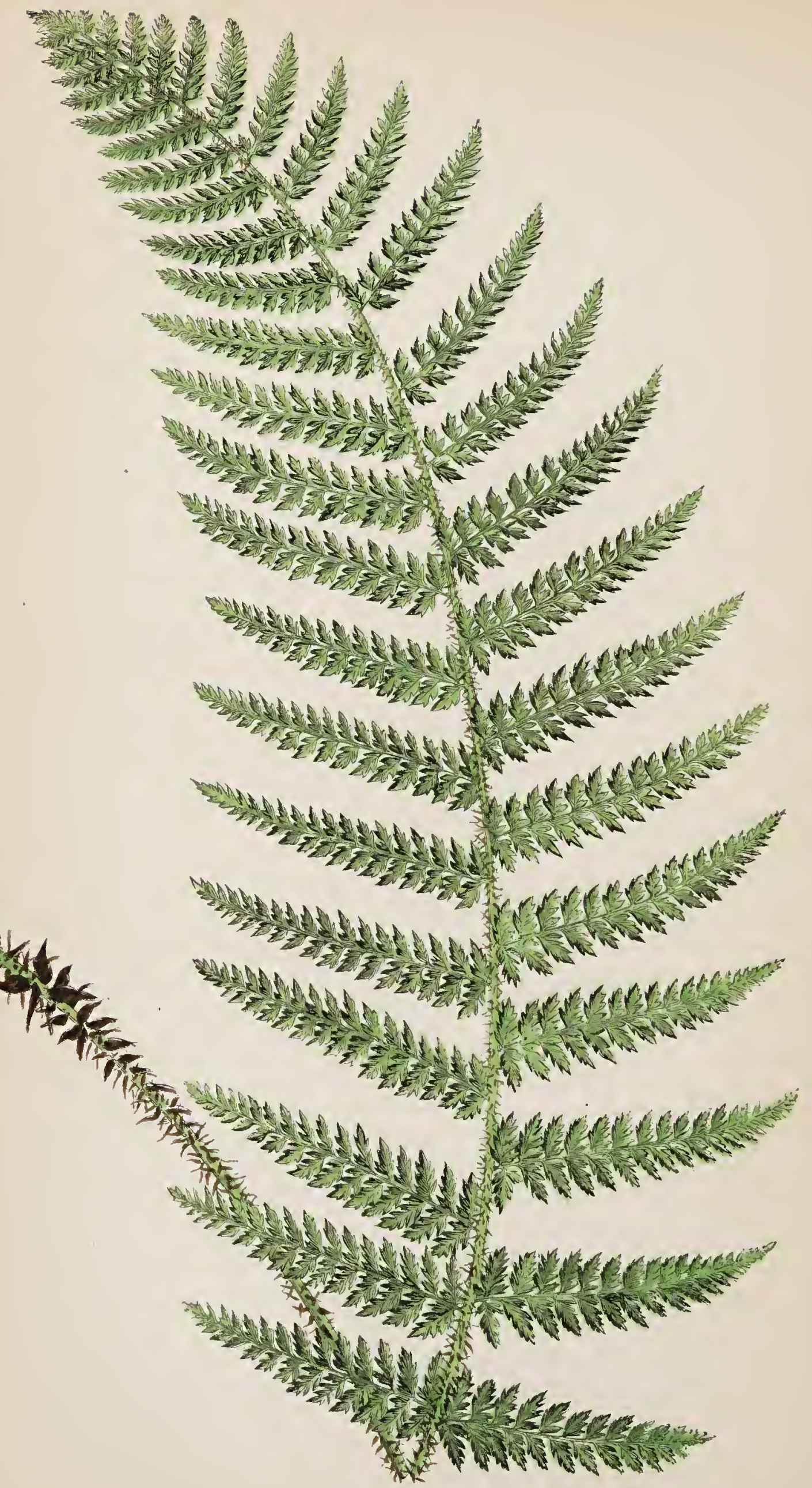


. . 



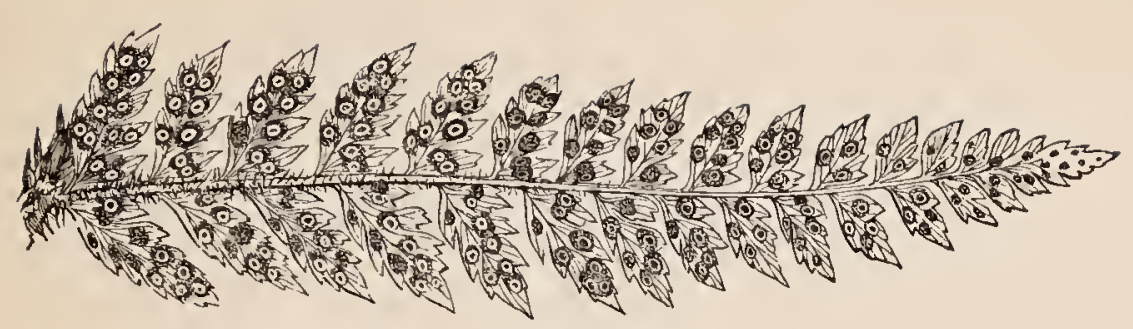

Pinma of mature Frond, under side.

\title{
ASPIDIUM PUNGE.NS.
}

\author{
Kaulfuss. Sprengel. Kunze. Schlechtendal. \\ (Not Waldich.)
}

\author{
PIATE VIII, VOI, VI.
}

\begin{abstract}
Polystichum pungens,
Prese Moore and Houlston.

is

J. Sмith. Link. FeE.

Polypodium aculeatum,

Thunberg. (Not of Linnaus.)
\end{abstract}

Aspidium-The Shield Fern. Tungens-Stinging.

Another very fine Fern, in the section Polystichum, bearing a viviparous plant near the apex of the frond from the midstem; the vivid shining dark green of the frond contrasts greatly with most other Ferns.

Native of the Cape of Good Hope.

Introduced into the Royal Gardens, Kew, by Mr. James Bowie, in 1823.

Fronds ovate-lanceolate in form; bipinnate, pinnules trapeziooblong, sub-falcate; upper base auriculate, lower base truncatecuneate, petiolate, profoundly serrate, with spinulose teeth on the edge of the pinnules. Terminal, adherent to a short creeping rhizoma.

Rachis and stipes scaly. 
Length of frond from eighteen to twenty-four inches; colour light green.

My obligations are due to Mr. Moore, of the Chelsea Botanic Gardens, and to Mr. Henderson, of Wentworth, for plants of this species.

It is in the Catalogues of Messrs. Kennedy, of Covent Garden; Stansfield, of Todmorden; Sim, of Foot's Cray; Rollisson, of 'l'ooting; Cooling, of Derby; and Young, of Taunton.

The illustration is from a plant in my own collection. 







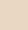







Portion of mature Frond, under side.

\section{ASPIDIUM FALCATUM.}

Swartz. Kunze. Willdenow.

PIATE IX. VOL. VI.

Cyrtomium fulcatum, "s

Polypodium falcatum, " japonicum,

Aspidium-The Shield Fern.
Presl. Moore and Houlston.

Sirith. Lisk. Fee.

Tilunberg. Linneus. Plukenet. HOUTTUYN.

Falcatum-Hooked.

In the Section Cyrtomium of Authors.

A vERY noble evergreen Fern with thiek fronds of a dark grcen colour, approaehing that of the Portugal Laurel; paler beneath, sori bold and pretty, being thickly scattered over the whole under surface of the frond. Easily grown, and freely propagating from spores, no one should be without this desirable Fern.

VOL. VI. 
An evergreen species, usually looked upon as a greenhouse or half-hardy Fern, yet last winter it lived out of doors without any protection; the fronds were cut with frost, but this spring the plants have put forth new fronds vigorously; consequently it is deciduous in this climate, yet quite hardy.

The colour of the frond is richer and darker when grown in the open air.

Raised at the Royal Gardens, Kew, in 1838.

Native of Japan.

Best known as the Cyrtomium falcatum.

Fronds lanceolate in form; pinuate, the pinnæ being shining and coriaceous, ovate-acuminate, falcate, repand, slightly rounded at the base, margin somewhat crenate; petiolate.

Rachis and stipes densely clothcd with huge brown scales.

Fronds terminal, adherent to an upright rhizoma.

Sori scattered over the under surface of the frond; indusium orbicular.

Length of frond from eighteen to thirty inches.

My thanks are due to Mr. Henderson, of Wentworth, and to Mr. Clarke, Curator of the Glasgow Botanic Gardens, for plants of this species; and to Mr. Norman, of Hull, and Mr. Clarke, of Glasgow, for fronds.

It is in the Catalogues of Messrs. Veitch, Jun., of Chelsea; Masters, of Canterbury; Osborn, of Fulham; Kennedy, of Covent Garden; Cooling, of Derby; Sim, of Foot's Cray; E. G. Henderson, of St. John's Wood; A. Henderson, of Pineapple Place; Veitch, of Exeter; and Stansfield, of Todmorden.

The illustration is from a plant in my own collection. 
- 


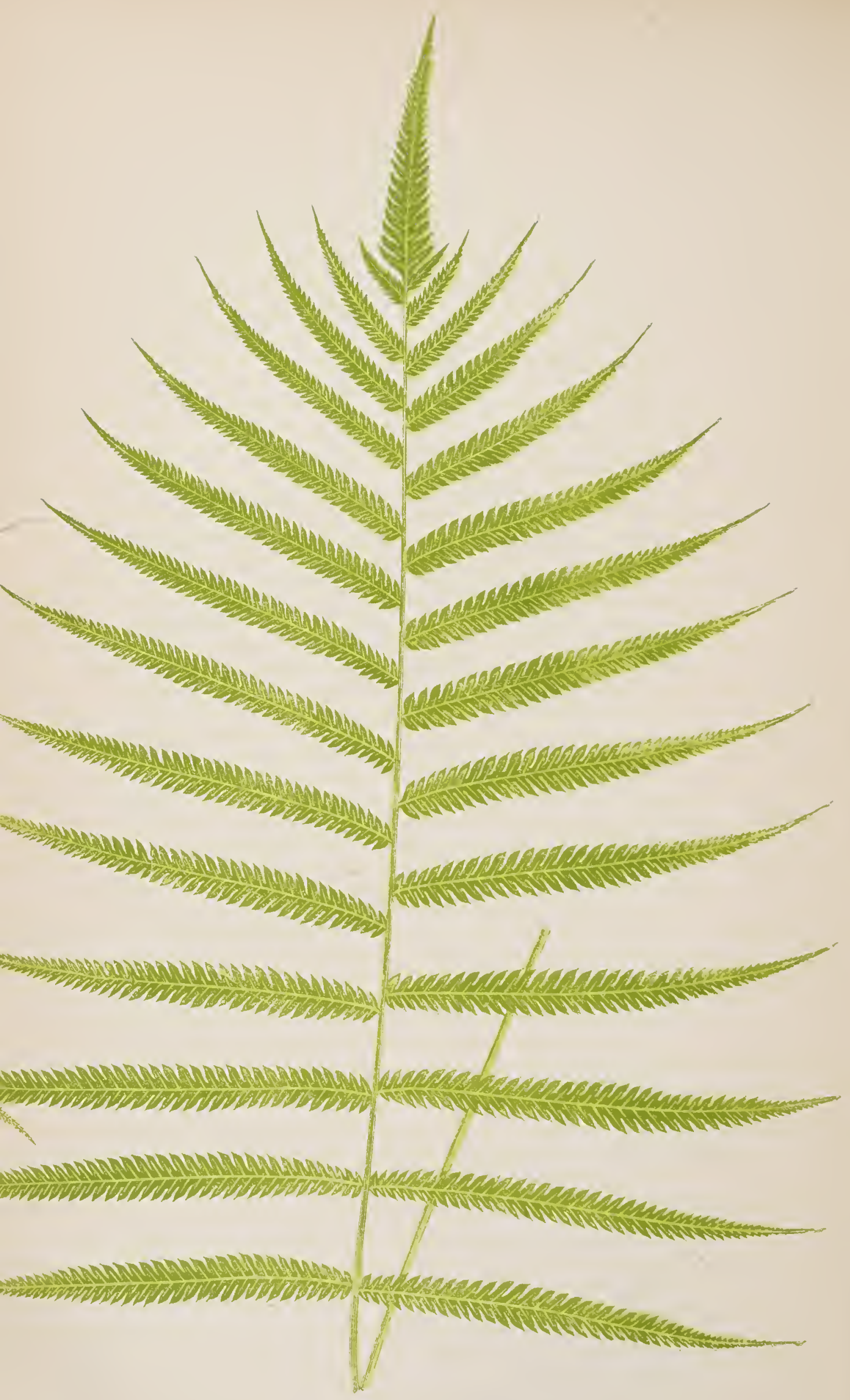




Portion of mature Frond, under side.

\section{ASPIDIUM AUGESCENS.}

Link. Kunze. Fee. Petiver. Plumier. Sloan.

PLATE X. VOL. VI.

$\begin{array}{ll}\text { Lastrea augescens, } & \text { J. Houlston. Mooke. SMItH. } \\ \text { Nephrodium Ottonis, } & \text { OF GARDENs. } \\ \text { Aspidium Ottonianum, } & \text { KUnzE. } \\ \text { Lastrea serra, } & \text { OF GARDENs. } \\ \text { Aspidium serra, } & \text { OF ScHotT. }\end{array}$

Aspidium-The Shield Fern.

Augescens-..........?

In the Section Lastrea of Authors.

Another ornamental Fern, with pale green fronds.

An evergreen stove species.

Native of Cuba, Venezuela, Caraccas, Mexico, and Caribee.

Fronds slender, semi-erect, broadly-lanceolate in form, pubescent, pinnate, the pinnæ being linear lanceolate, (very narrow for their length,) sessile, pinnatifid, the segments being rigid, small, oblong-obtuse, and largest nearest the rachis. Fronds lateral, adherent to a creeping rhizoma.

Length from three to four feet; colour pale green.

Sori medial, and often only partial. Indusium hairy.

Best known as the Lastrea augescens.

My thanks are due to Messrs. Veitch, of Exeter; Messrs. 
Veitch, Jun., of Chelsea; and to Messrs. Booth, of Hamburg, for plants of this species; and to Mr. J. Henderson, of Wentworth, and to Mr. Norman, of Hull, for fronds.

It is contained in the Catalogues of Messrs. A. Henderson, of Pine-apple Place; Stansfield, of Todmorden; Veitch, of Exeter; Veitch, Jun., of Chelsea; Kennedy, of Covent Garden; Rollisson, of Tooting; Sim, of Foot's Cray; and Cooling, of Derby.

The illustration is from a plant in my own collection. 



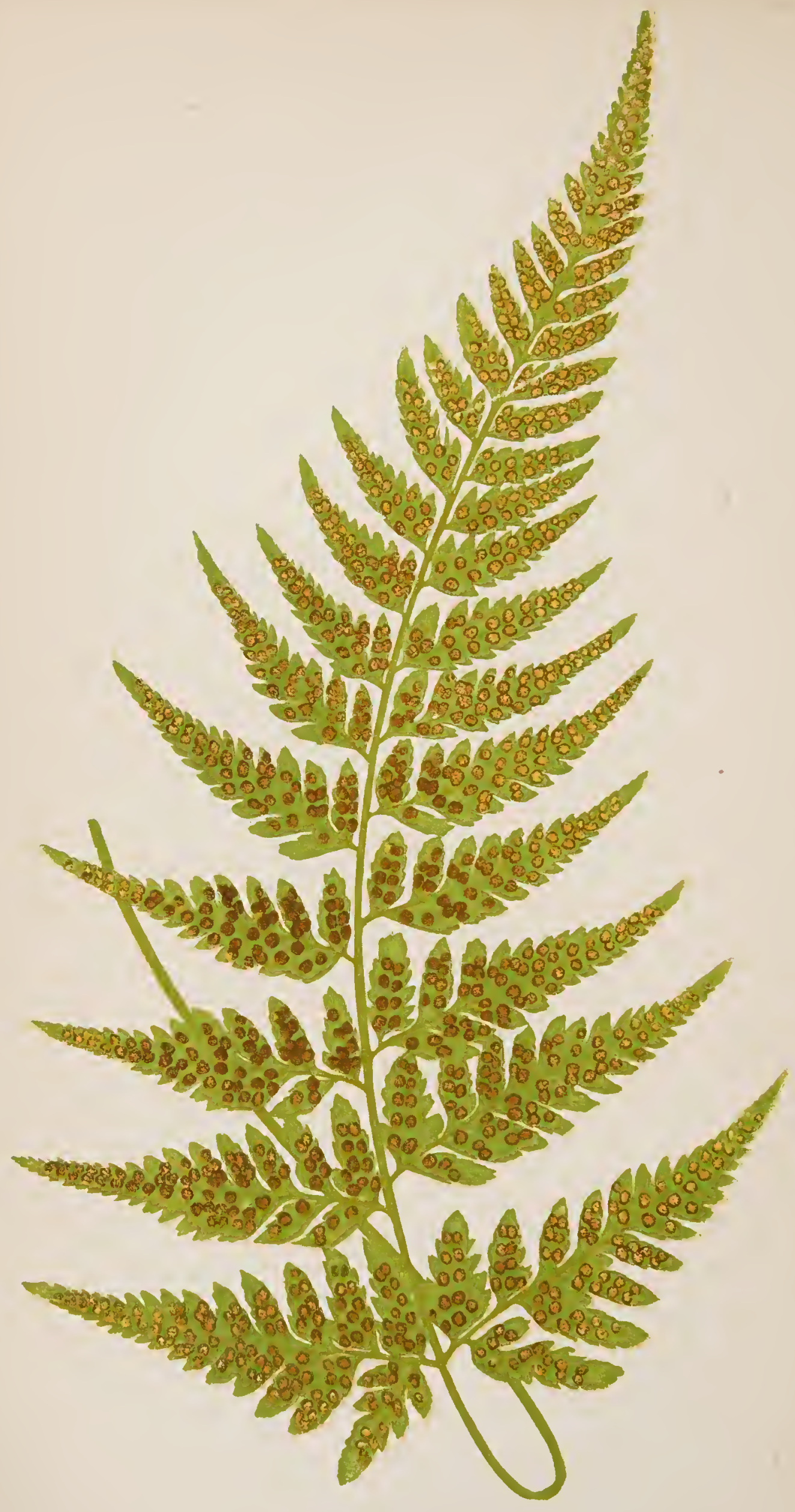





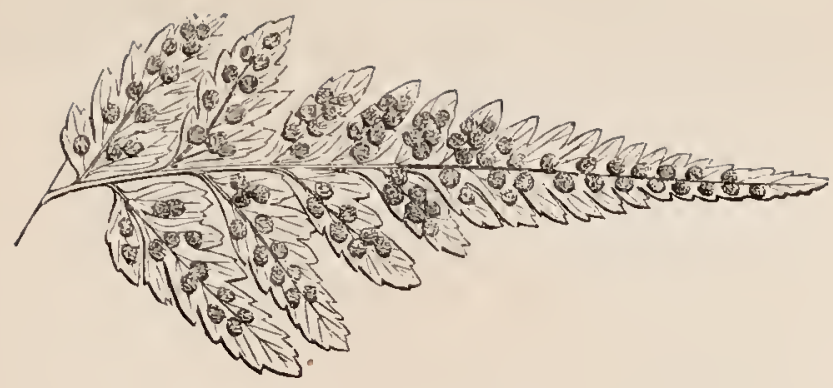

Portion of mature Frond, Cunder side.

\section{ASPIDIUM ACUMINATUM.}

WiLLDENOW.

PIATE XI. VOL. VI.

Lastrea acuminata, "Rileyana,

Lepidonevron acuminatum,

Aspidium-The Shield Fern.
J. Houlston. Moore. Of Gardens.

FEE.

Acuminatum-Long-pointed.

In the Section Lastrea of Authors.

A PRETTY dwarf evergreen Fern, yet from what country it is rather doubtful, probably Nepal.

An evergreen warm greenhouse or stove species.

Fronds glabrous, triangularly-elongate, bipinnate; pinnæ being triangularly elongate-acuminate; pinnules oblong-ovate, except the lower ones, which are entire, and in a slight degree pinnatifid; the upper pinnules are decurrent at the base, and rigidly dentate.

Fronds terminal, adherent to a slightly tufted rhizoma.

Sori medial.

Length of frond twelve to fifteen inches; colour a heavy green. For plants of this species I am indebted to Mr. Moore, of the Chelsea Botanic Gardens; and to Mr. J. Henderson, of Wentworth. 
It is in the Catalogues of Messrs. Veitch, Jun., of Chelsea; R. Sim, of Foot's Cray; and Rollisson, of Tooting. The illustration is from a plant in my own collection. 




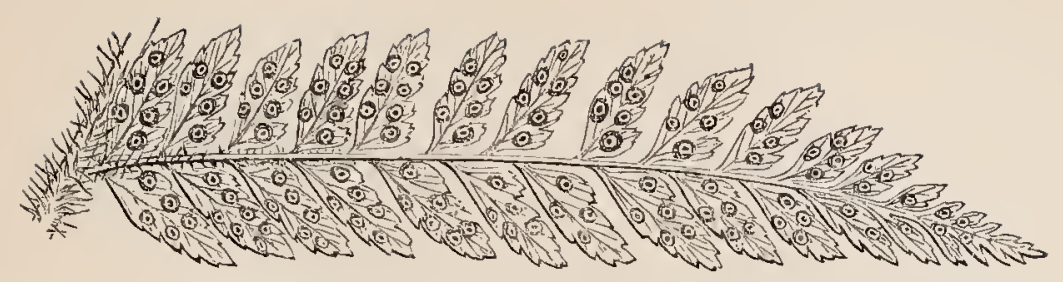

Portion of mature Frond, under side.

\section{ASPIDIUM PROLIFERUM.}

R. Brown. Kunze, (not of Hooker and Greville.) Kaulfuss. Sprengel.

PLATE XII. VOL. VI.

Polystichum proliferum,

Aspidium vestitum,

Polystichum stramineum,

Aspidium-The Shield Fern.
Presl. Moore and Houlston. J. SмIтH.

Willdenow, (not of SWartz, Sieber, ScHzUHR, nor FEe.) Veitch's, ‘Jun., Catalogue.

Proliferum-Proliferous.

In the Section Polystichum of Authors.

AGaIN it is requisite to remark "a handsome plant when well grown;" and also, like Aspidium pungens, viviparous near the apex of the frond.

An evergreen warm greenhouse Fern.

Native of Van Diemen's Land, (Tasmania,) and New Holland.

Received into the Royal Gardens, Kew, from Messrs. Osborn, in 1843 .

Fronds linear-lanceolate in form, bipinnate; pinnules petiolate, oblong-ovate, obtuse, sub-falcate; superior base in a small degree auriculate; margin bluntly toothed. Terminal, adherent to a thick tufted rhizoma.

Rachis and stipes paleaceous. 
Length from eighteen to twenty-four inches; colour dull green. My thanks are due to Mr. Moore, of the Chelsea Botanic Gardens, and to Mr. Henderson, of Wentworth, for plants of this species.

It is in the Fern Catalogues of Messrs. A. Henderson, of Pine-apple Place; Sim, of Foot's Cray; Kennedy, of Covent Garden; Veitch, Jun., of Chelsea; Stansfield, of Todmorden; E. Cooling, of Derby; and Young, of Taunton.

The illustration is from a plant in my own collection. 



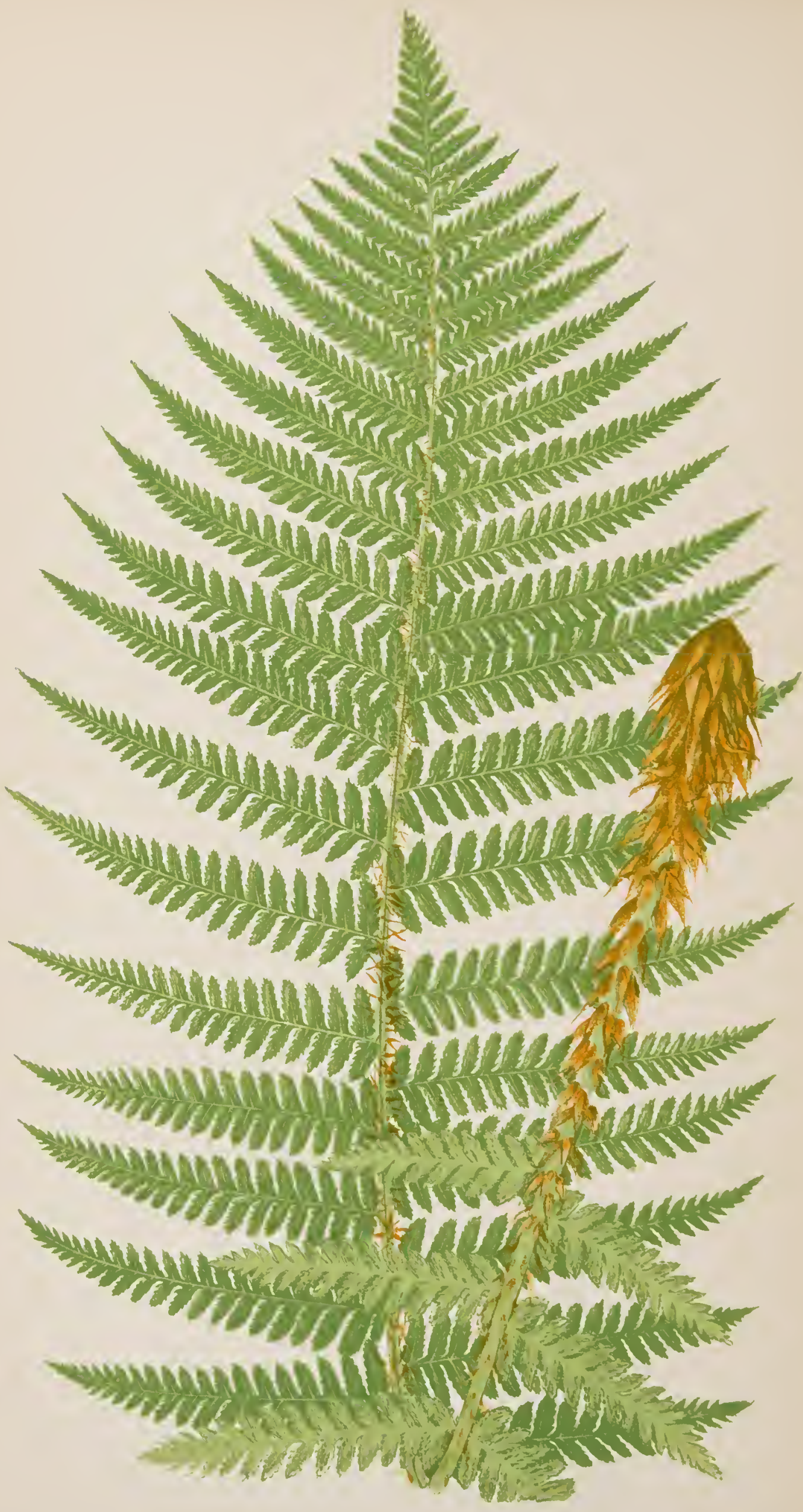

ASPIDIUM FILIX-MAS, 




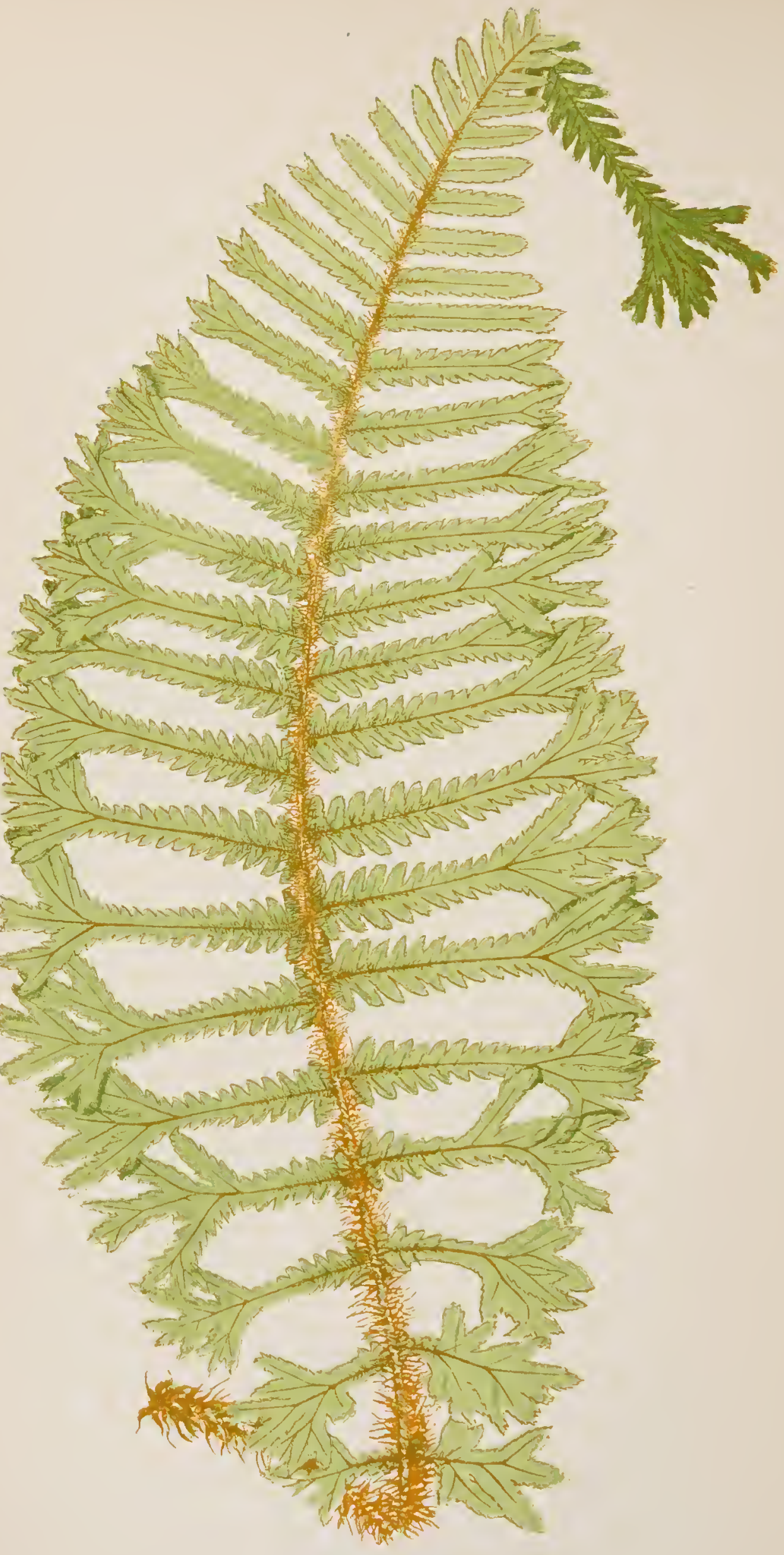




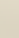




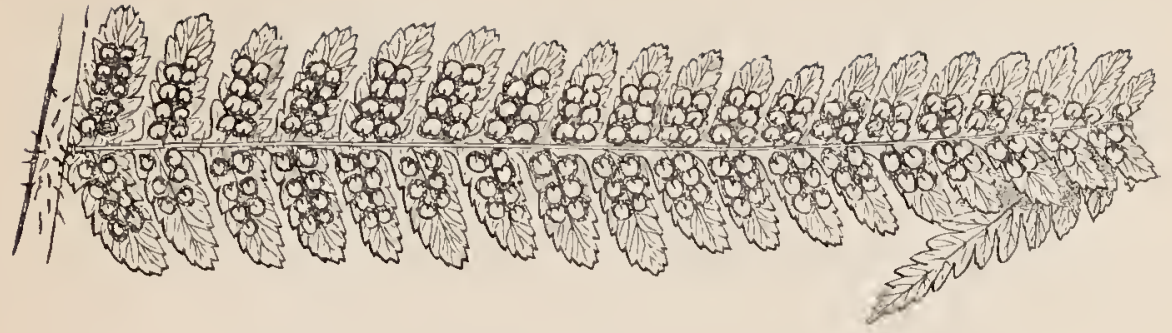

f Pinna of mature Frond, under side.

\title{
ASPIDIUM FILIX-MAS.
}

Strartz. Shith. Schicuir. Hooker and Arnott. Mackay. Fee. Willdenow. Sprengel. Kunze. Link.

\author{
PLATES XIII AND XIV. VOL. VI.
}

Lastrea Filix-mas,

“6

" erosa,

" affinis,

" paleacea,

" patentissima,

Polystichum Filix-mas, " affine,

Polypodium Filix-mas, " nemorale,

" Heleopteris,

Dryopteris Filix-mas, " affinis, " Borreri,

Lophodium Filix-mas, " erosum, Aspidium nemorale, " depastum, " affine,

YOL. VI.
Presl. Babington. Sowerby.

Moore. NETMAN.

$\left.\begin{array}{l}\text { Deakrs. } \\ \text { Moore. }\end{array}\right\}$ "The variety incisum."

Moore. $\}$ "The variety paleaccum."

Proth. De Candolle.

LEDEBOUR. "The variety incisum."

LinNeus. Bolton.

SatisBury.

Borrmausen. "The varicty incisum." Schott. Newman.

Newman. "The variety incisum."

Newman. "The varicty palcaceum."

NEWMaN.

Newmax. "Tho varicty incisum."

GRAY.

$\left.\begin{array}{l}\text { Schínt. } \\ \text { Fischer \& Merer. }\end{array}\right\}$ "Tho var. incisum." 
$\left.\begin{array}{cl}\text { Aspidium paleaceum, } & \text { DON. } \\ \text { " patentissimum, } & \text { WALLICH. } \\ \text { " Donianum, } & \text { SPRENGEL. } \\ \text { Nephrodium affine, } & \text { SPRENGEL. } \\ \text { Dichasium patentissimum, } & \text { BOWE. } \\ \text { BRAUN. FEE. }\end{array}\right\}$ "The var. paleaceum."

Aspidium-The Shield Fern. Filix-mas-Male Fern.

In the Section Lastrea of Authors.

Although so common a species, still it is a noble Fern, and being hardy and easily grown in almost every situation, it is a favourite amongst cultivators of plants.

It is to be found lining the sides of ditches, the margins of rivers and lakes, the edges of cliffs and crevices of rocks, be they moist or dry, no matter what their geological construction, becoming a principal undergrowth in many woods, and even growing where the salt waves of the sea can occasionally wash over them. Subject to great variety when raised from spores, and many of the varieties permanent, and some of them exceedingly handsome. The variety cristatum, of which a coloured illustration is given on Plate XIV., is a glorious object when well grown. Mr. Moore, in the "Nature-Printed Ferns," has given an excellent description of the principal varieties, to which the reader is referred, as the limited space devoted to each species will not allow of a more than brief extract from Mr. Moore's descriptions. The varieties given are the following:-

Lastrea Filix-mas, Moore. Varieties:-

1.-Paleacea, Moore. (Var. Borreri, Johnson, Newman; var. pseudo-mas, Wollaston.) Mr. Wollaston considers it a distinct species. It is by no means uncommon, and differs from the ordinary form of Filix-mas in having a somewhat yellow appearance, slightly glaucous beneath, stipes and rachis shaggy, scales golden brown, ribs and veins purple.

2.-Multifida, Wollaston. Apex of frond, and of some of the pinnæ bifid or multifid.

3.-Cristata, Moore. (Plate XIV.) This glorious variety has the apices of all the pinne beautifully and uniformly tasseled. The pinnæ are shorter, and narrow rapidly towards the tassel. 
Found at Charleston, near St. Austell, in Cornwall. Somewhat similar plants have bcen found in Staffordshire and Devonshire.

4.- Prolifcra, Wollaston. 'Tasseled like cristata, but more crisped, depauperated, and laciniated. It also bcars bulbils.

5.-Dichotoma, Wollaston. Somewhat resembles multifida, but has not the golden scales of that varicty.

6.-Incisa, Moore. (Var. crosum, Hooker and Arnott, Döll, Newman; var. affinis, Newman.) Upright in habit, larger than the normal form, common, distinctly bipinnatc, and sori covering nearly the whole length of the pinnules.

7.-Erosa, Wollaston. Laciniatcd, looking as if nibbled by insects.

8.-Dcorso-lobata, Moore. A common large Fern in the incisa group.

9.-Producta, Moore. Large, and somewhat analogous to incisa; sori confined to the upper third of the frond. Found at Wrekin, in Shropshire, by the Rev. W. A. Leighton.

10.-Triangularis, Noore. In the incisa group, somewhat resembling Lastrea cristata. Found in Kent by Dr. Allchin.

11.-Polydactyla, Moore. Differs from cristata in the pinna not being shortened, and do not narrow much until quite close to the tasseled ends. Found at Bromsgrove, in Worcestershire, by Mr. B. Maund.

12.-Abbreviata, Babington, Johnson, and Newman. Dwarf, glandular, and fragrant, with larger pinnules than in pumila. Sori mostly uniserial. Found at Snowdon, Ingleborough, 'Teesdale, and Wyck, (Gloucestershire.) Lately I saw many plants on the hills to the east of Grasmere Lake.

13.-Pumila, Moore. (Var. ablreviata of Moore, and recurvum of Francis.) Somcwhat similar to abbreviata. The points of the pinnæ and pinnules recurve, giving a concave appearance on the upper surface. A dwarf species, confined to North Wales and alpine districts. Mr. Wollaston considers it a distinct spccics, in which I perfectly agree, and have conscquently figurcd it under the namc of Aspidium pumitum.

14. - Subintegra, Moore. Closcly allied to abbreviala and pumila. Abundant at Ennis, County Clare, Ireland, where it was found by the Rev. J. Baird.

The three last-mentioned varieties of Mr. Moore's list appcar to be different forms of the samc Fcrn, and this a distinct 
species from Aspidium Filix-mas. 'The dwarf permanent form and peculiar character of the sori renders it very distinct from A. Fitix-mas, and I do not doubt that before very long it will be separated from that species by the universal consent of botanists, and at the same time the dwarf so-called form of Asplenium Filix-fomina, known as the variety acuminatum, will also be raised to the honourable dignity of a species. Lately I have seen much of this latter Fern in the lake district of TVestmorland and Cumberland, mostly growing in alpine situations, yet having the normal form of Asplenium Filix-formina growing amongst it. Mostly it is the companion of Aspidium oreopteris. It is a common and widely-spread Fern in hilly districts.

Turning to the normal form of Aspidium Filix-mas, the fronds arc lanceolate, bipinnatc, with linear pinna tapering to the apcx; pinnules oblong-obtuse, with the margin serrate, crenate, or inciso-lobate. Caudex large, tufted, scaly, erect, or decumbent. Stipes short, stout, covered with scales. Rachis slightly covered with small scales. Pinnæ numerous. Veins branched.

Sori numerous, distinct, roundish, reniform, medial. Indusium convex, persistent, reniform, margin entire, destitute of marginal glands.

Length of frond usually from two to threc feet, occasionally as much as six feet; colour deep green, smooth and bright.

A deciduous hardy indigenous species common throughout the whole of Europe. In Russian Asia, along the Altai and Himalaya from Kumaon through Nepal to Assam, in some parts of India, North Africa, Madeira, Mexico, Guatemala, Ncw Granada, Ecuador, Brazil, Peru, and Caraccas.

For plants of this Fern I am indebted for the variety paleaeea to Mr. Sim, of Foot's Cray; for the variety cristata to Mr. Wollaston, of Chiselhurst; Messrs. Rollisson, of Tooting; and Mr. Sim, of Foot's Cray; for the variety erosa to MIr. Clapham, of Scarbro'; for the variety polydactyla to Mr. Stansfield, of Todmorden; and for fronds of eristata to Mr. Henderson, of Wentworth, and to Mr. Grey, of St. Thomas', Exeter.

The varicty paleaeea I have found abundant about Stockgill Force, Ambleside, and ncar Rydal Lake, and ncar Windermcrc, about Lowood.

The varicty deorso-lobata about Ambleside, and at Matlock and Wollaton. 
The variety incisa at Wollaton.

Several other varịeties, more or less distinet from the normal form were found about Ambleside, Grasmere, Rydal, Kendal, Penrith, Wyburn, and Brathay, in the lake distriets of Westmorland and Cumberland, at Noreeombe Bay, Laneashire, and about the falls of the Calder and Snout, in Durham.

The varieties bear the names as if they were the varieties of Lastrea instead of Aspidium; the gender las not been altered, as they represent varieties of the section Lastrca.

The Male Fern is too eommon to need a reeord of the Nurserymen who keep it. The variety cristata ean be proeured of W. Cutbush, of Highgate; palcacca and cristata of J. Young, of Taunton; the varieties incisa and cristata of Bass and Brown, of Sudbury; the variety cristata of Veiteh, of Chelsea; cristata of A. Henderson, of Pine-apple Plaee; the varieties incisa, cristata, palcacea, and crispa of R. Sim, of Foot's Cray; the varieties cristata, crosa, incisa, paleacca, and polydactyla of A. Stansfield, of Todmorden; palcacca and cristata of E. Cooling, of Derby; cristata of IV. Rollisson, of Tooting; incisa, crosa, and cristata of R. Kennedy, of Covent Garden.

The variety cristata is so remarkably handsome that it has been deemed desirable to give a eoloured illustration. These illustrations are from plants in my own colleetion.

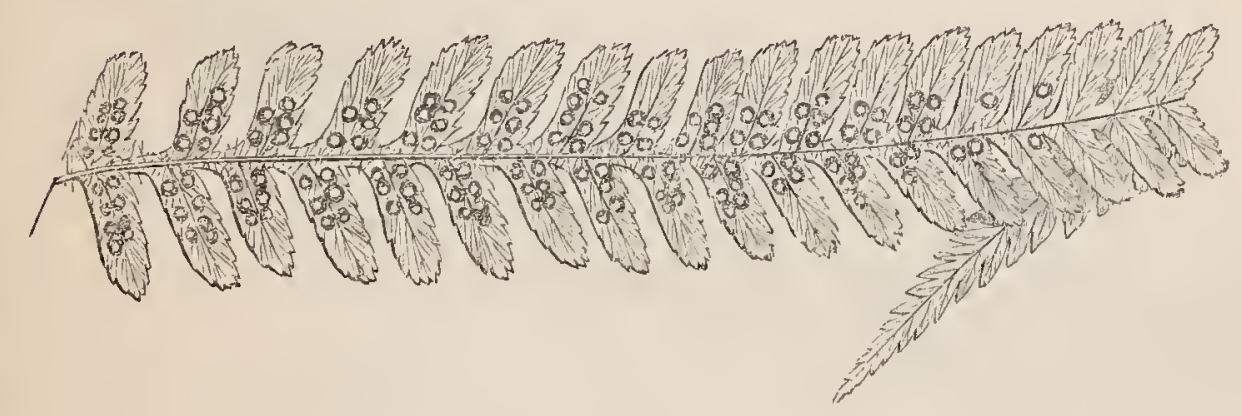

Variety Ineínm 


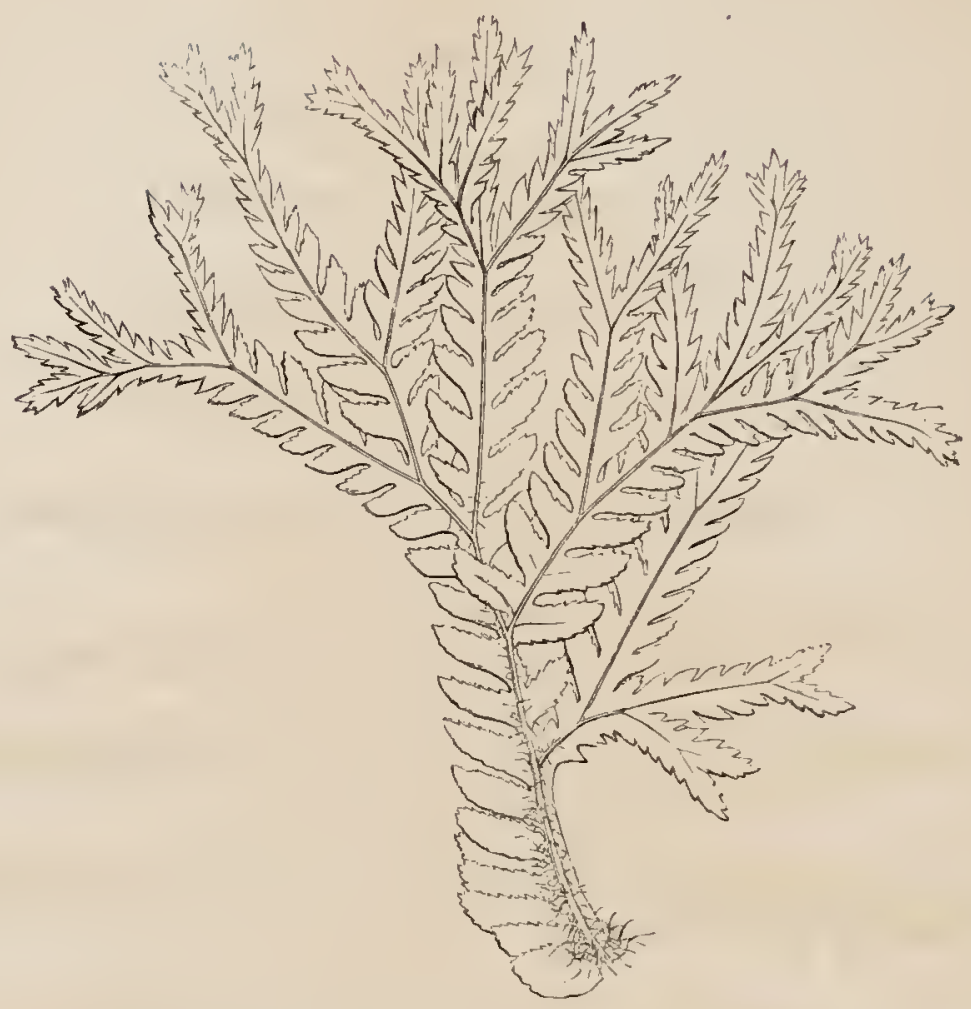

One of the forms of the variety Cristata,

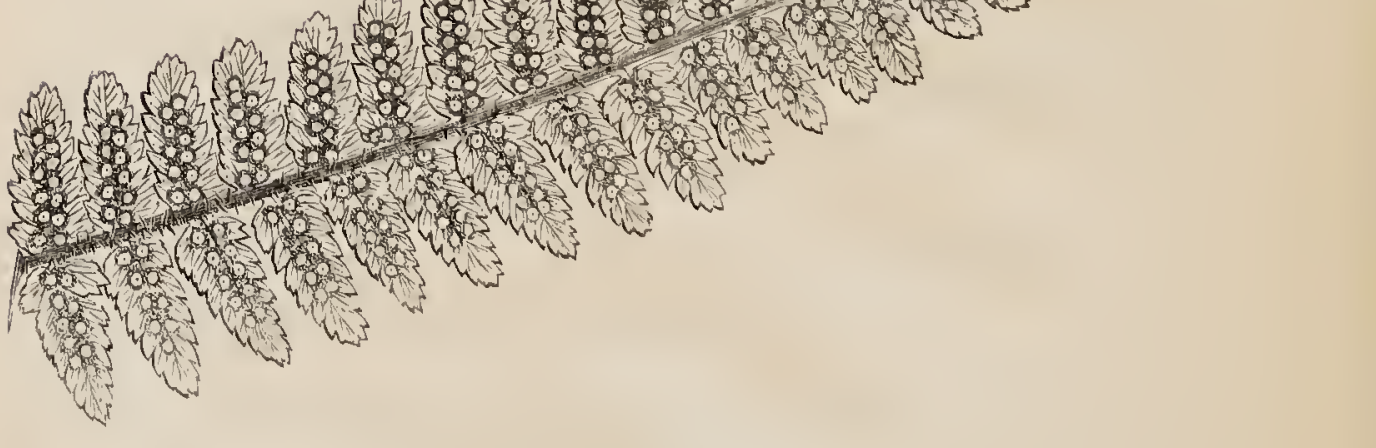

Vuriety Palcacen. 


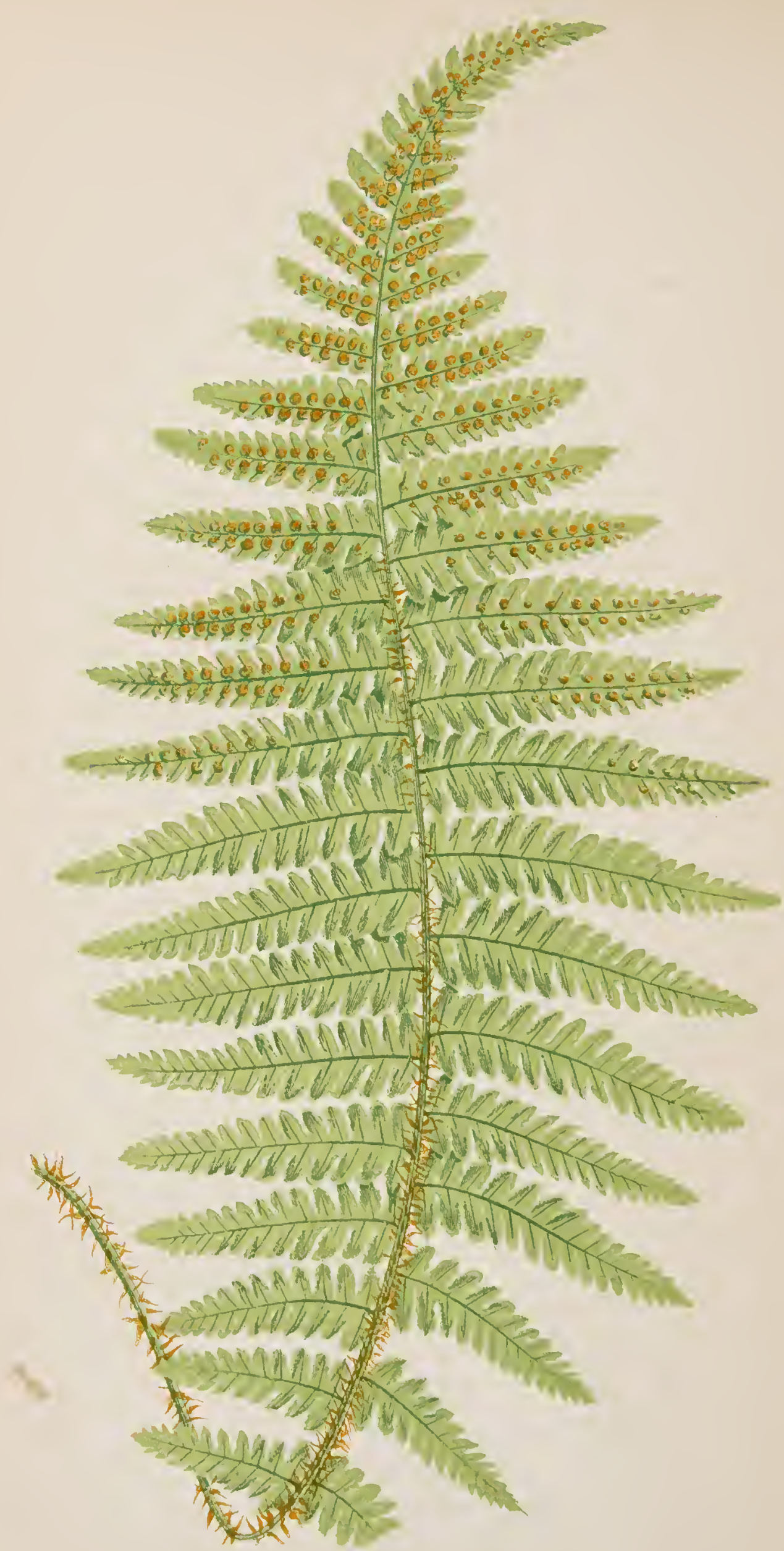

A SPIDIUM PUMILUM. 


Pinna of mature Frond, under síde.

\section{ASPIDIUM PUMILUM.}

LOWE.

PLATE XV. VOL. VI.

Lastrea pumila,

" Filix-mas, var. abbreviata, Aspidium Filix-mas, var. recurvum,

" Filix-mas, var. pumilum,

Lastrea Filix-mas, var. abbreviata,

"6

"abbreviata,

Polystichum abbreviatum,

Lophodium abbreviatum,

Dryopteris ablreviata,

Filix-mas, var. abbreviata,

Lastrea Filix-mas subintegra,

Aspidium-The Shield Fern.
Moore.

Moore.

Francis.

Of Gardens.

Babington.

JOHNSON.

MOORE.

De Candolle. $\}$ "The variety

Newaran.

Newman.

Newman.

Moore. "The var. subintegra of Moore."

Pumilum-Dwarf.

\section{In the Section Lastrea of Authors.}

Although generally looked upon as a variety of Aspidium Filix-mas, still its characters are very distinct, so much so as to induce me to figure it as a species.

A hardy deciduous Fern, remaining green and fresh later in the year than $A$. Fillix-mas.

An alpine species. 
The normal form being found in North Wales, Snowdon, and Llyn Ogwen; the variety abbreviatum on Snowdon, on the hills of Westmorland and Cumberland, at Ingleborough, at Wyck, in Gloucestershire, and in 'Teesdale; and the variety subintegrum abundantly at Ennis, in County Clare, Ireland.

A dwarf species.

Fronds lanceolate, pinnate. The pinnæ blunt, rather deflexed, and pinnatifid. Pinnules small, oblong-obtuse, convex. Fronds glandular. The points of the pinnæ and pinnules recurving.

Sori, a single sorus near the base of the pinnules, on the anterior side, forming a single row on either side of their rachis or midrib.

Fronds fragrant. Indusium leaden in colour. Stipes two to three inches in length.

Length of frond nine to twelve inches; colour dull green.

The variety abtreviatum has larger pinnules, and is not so much recurved. Indusia as in $A$. pumilum, marginal with glands, and fragrant. The variety sutintegrum is narrow and lance-shaped.

For a plant of this species I am indebted to Mr. Pearson, of Chilwell.

It is in the Catalogues of Mr. W. Cutbush, of Highgate; Pearson, of Chilwell; J. Young, of Taunton; Masters, of Canterbury; A. Henderson, of Pine-applc Place; R. Sim, of Foot's Cray; A. Stansfield, of Todmorden; W. Rollisson, of Tooting; and R. Kennedy, of Covent Garden.

The illustration is from a plant in my own collection. 



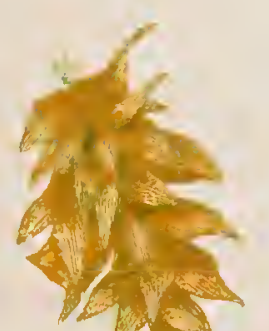

.

.

$\mathrm{C}^{2}$

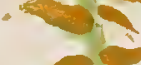

10

23

$\rightarrow(x+4$

any 20

$+4+2$

$12+2$

$t_{1}=$

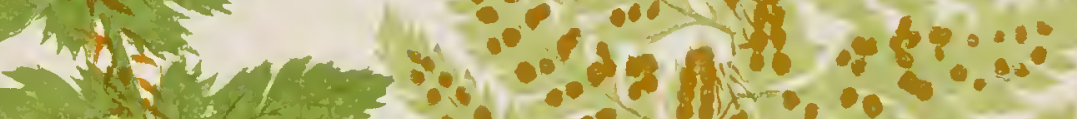

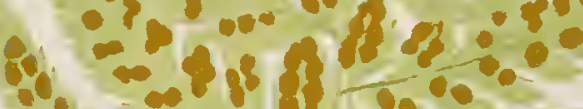

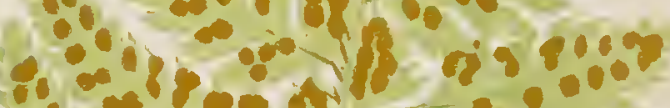

bo $c=8$ s

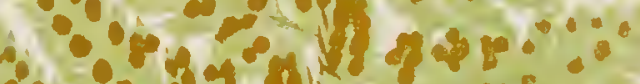

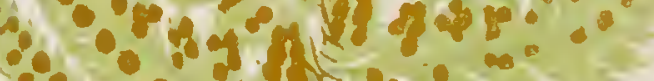

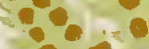

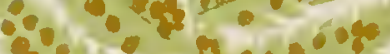

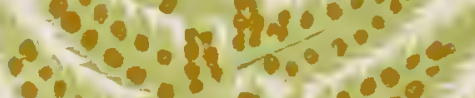

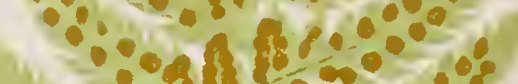

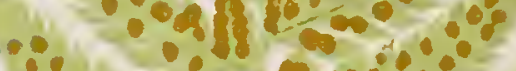

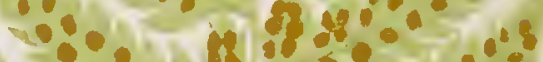

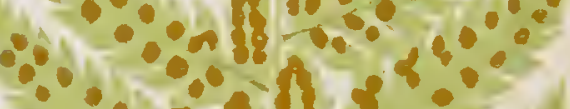

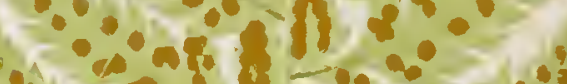

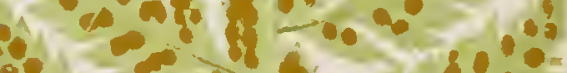



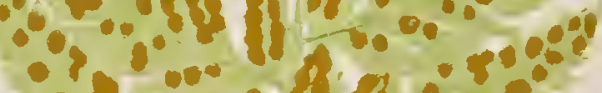

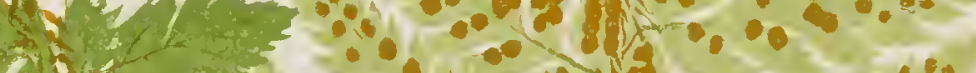

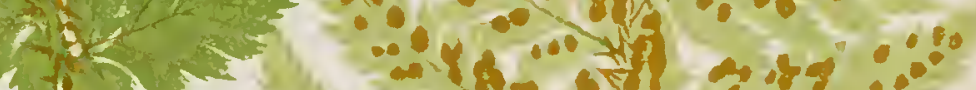
I.

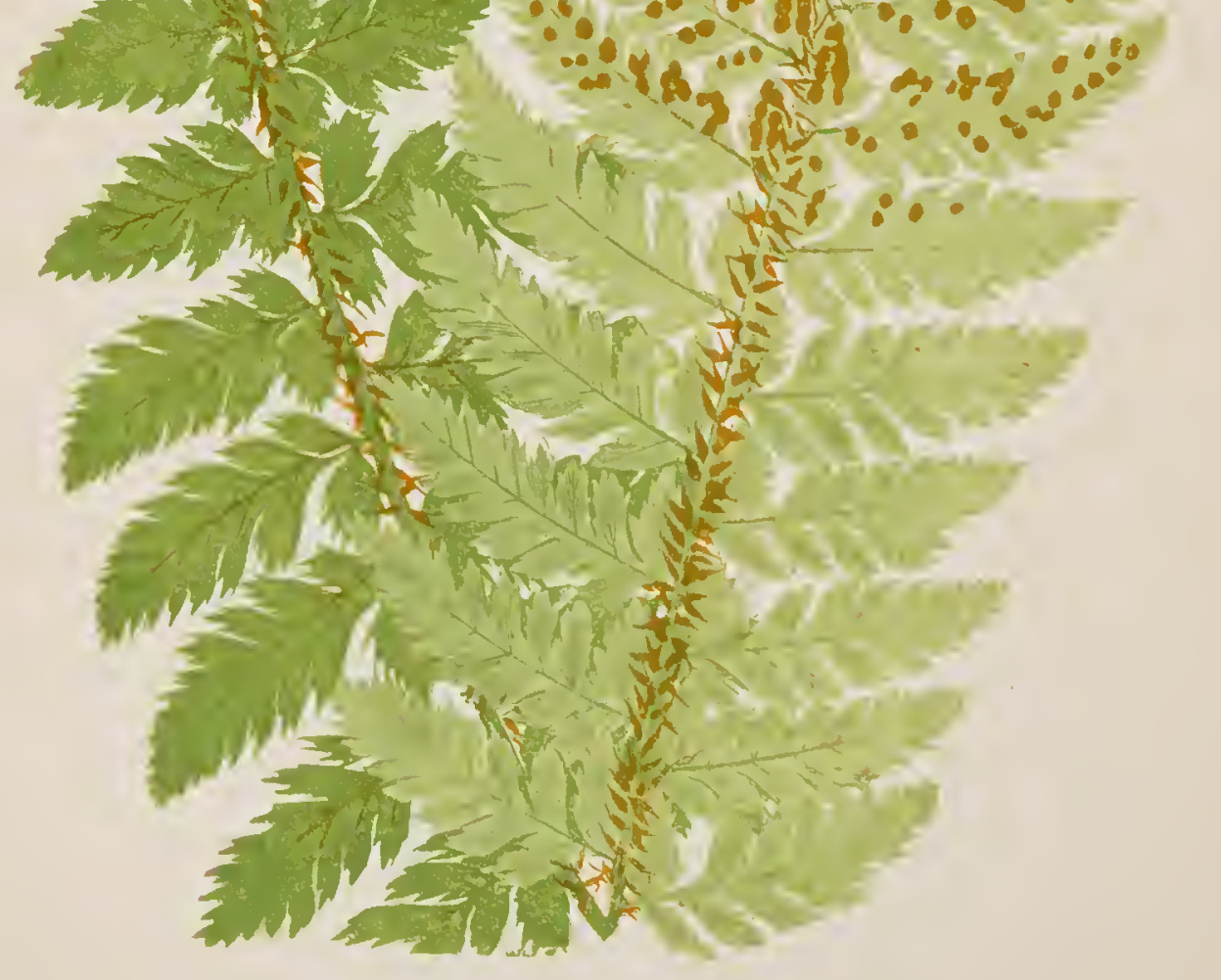

ASPIDIUM ACULEATUM. 


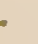





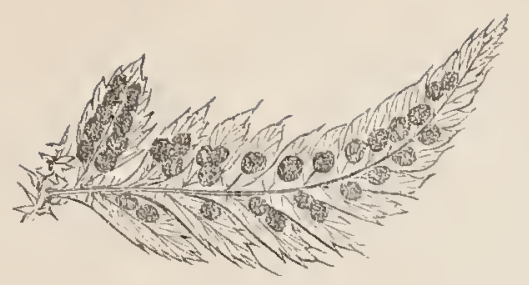

Pimma of mature Frome, mombly sids.

\section{ASPIDIUM ACULEATUN.}

\section{Swartz. Smith. Hooker and Arnott. Willdenow. Sprengel. Schkuhr. Kunze.}

PIATE XVI. TOL. TI.

Polystichum aculeatum,

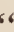

6

" lobatum,

“. "

" aculeatum,

" Plukenetii,

" aculeatum var.

$\left.\begin{array}{l}\text { aculeatum var. } \\ \text { lonchitidioides, }\end{array}\right\}$

6

; aculeatum var. lobatum,

Polyrodium aculeatum,

$$
\begin{array}{ll}
\text { " lobatum, } \\
\text { " aculcatum, } \\
\text { Plukenctii, }
\end{array}
$$

Aspilium lobatum,

.. discretum,

" lobatum,

،

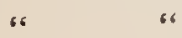

64

" " "

" aculeatum,

"Plukenctii,

VOL. VI.
Roth. Deakin, Babington. Sowerby. Newman. Moore. Prest. Fee. Iink. Schott. Presl. Linti.

SOTHERB.

Newman.

De Cannolie. "The var.

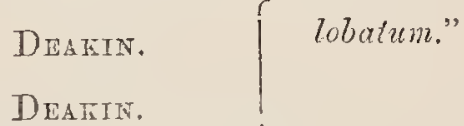

Moote. Fev.

LINNAUS.

Hudson. ? "The rar.

Hudson. $\}$ Tubatum."

ScIIfUtr. TíUnze.

Dor.

Swartz. Smiter.

Hooker AND ArvotT.

WrLLDENOW.

MACKAY.

The var.

HoOKER AND ARROTT. lobutm.

Schisurl.

Steuded. 


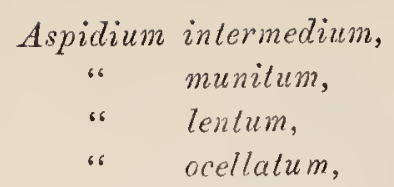

Aspidium-The Shiold Fern. $\left.\begin{array}{l}\text { SADLER. } \\ \text { SADLER. } \\ \text { Don. } \\ \text { WaLLICI. }\end{array}\right\}$ The var. lobatum.

Aculeatum-Prickly.

In the Sectron Polystichuli of Authors.

A Most interesting species of handsome growth, and having brilliant shining fronds. Growing in shady situations. It is by no means an uncommon British plant, being found in almost every county in England, Scotland, and Ireland, and the Channel Islands, from the sea-level to two thousand feet elevation.

Common throughout the whole of Europe, (except, perhaps, the counties of Greece and Turkey;) from Scandinavia to Spain. Russian Asia, British India, Algiers, Madeira, America, from Eastern United States to Columbia.

An evergreen indigenous species.

Caudex thick and tufted. Stipes short, three to four inches in length, densely scaly. Rachis stout and densely scaly.

Fronds bipinnate, lanceolate, or broadly linear-lanceolate, rigid; pinnæ numerous, obliquely lanceolate, broadest at the base, acuminate, pinnate at the base, and sometimes nearly to the apex; pinnules somewhat elliptic, acute, and aristate at the apex, auriculate on the anterior side, and being acute and mucronate, aristate and subsessile, attached by the cuneate base, or decurrent. The basal anterior pinna larger than the rest.

Veins branched. Fructification mostly confined to the upper half of the frond.

Sori circular, indusiate, eventually becoming confluent or crowded. Indusium membranaceous, orbicular, peltate, and umbilicate.

Length of frond from one to three feet, rigid, leathery, smooth, and dark shining green above; paler beneath.

'There is a similarity between Aspidium aculeatum and the A. angulare, at least to those not well versed in Ferns; the former, however, is more rigid, upright, and stouter in its growth, 
has medial sori, and is evergreen; the latter is herbaceous, deciduous, and lax.

The present species is subject to much variation. Mr. Moore describes five distinct varieties, namely:-

1.-Lonchitidioides. Somewhat resembles A. lonchitis.

2.-Lobatum. Has narrow lance-shaped fronds from one to two feet long, and sub-bipinnate.

3.-Multifidum, Wollaston. Apex multifid.

4.-Proliferum, Wollaston. Produces bulbils in axils of the lower pinnæ.

5.-Argutum. Broadly lanceolate, the pinnules being narrow and elongate, terminate in an acute spiny point, and have long spines to the marginal teetl.

A. aculcatum is best known under the name of Polystichum aculeatum.

Situation appears to exert great influence over this species, the common form growing near Beeston, is very different to that at Chaigely, Lancashire, or Rydal, Westmorland.

The variety lonchitidioides, I am indebted to Mr. Stansficld, of Todmorden, for plants of; others I have gathered wild in Patterdale. A dwarf form is very abundant on a moist shady bank at Chaigely Manor, Lancashire, and an intermediate variety almost connecting $A$. aculeatum with $A$. angulare $I$ have received plants of from Sir Oswald Mosley, Bart., of Rolleston Hall, near Burton-on-Trent, in whose Fernery $I$ have seen most of the varieties of $A$. aculeatum flourishing most luxuriantly.

This common Fern can be procured of all the Nurserymen; the varieties lobatum and lobatum-incisum of W. Cutbush, of Highgate; lobatum of J. Young, of Taunton; lobatum of Veitch, of Chelsea; lobatum and lonchitidioidcs of E. G. Henderson, of St. John's Wood; lobatum and proliforum of R. Sim, of Foot's Cray; lobatum and lonchitidioides of A. Stansfield, of Todmorden; lobatum and lobatum-incisum, of W. Rollisson, of 'Tooting; and lobatum and lonchitidioides of R. Kennedy, of Covent Garden.

The illustration is from a plant in my own collection. 

. 
In the lake districts of Westmorland and Cumberland it is very abundant.

Extends over the whole of Europe.

Fronds pinnate, lanceolate in form; pinnæ opposite, the basal ones obtusely triangular, about the centre of the frond linearlanceolate.

Veins forked, and bearing sori near the apices.

Sori moderate-sized, round, forming a sub-marginal series.

Indusium small and thin.

Length of frond from one to three feet. Colour brilliant green.

The fronds of this species are fragrant.

Mr. Moore, in the "Nature-printed Ferns," gives two varieties:

1st.-Truncata, Wollaston. Found near Tunbridge Wells by Mr. Wollaston. A monstrosity, having the apices of the frond and pinnæ ending abruptly.

2nd.-Crispa, Moore. Found on the Clova Mountains by Dr. Balfour. The pinnules are undulated.

Plants of this Fern I have gathered wild at Oxton Bogs and Bulwell, Nottinghamshire; at Wincham, near Northwich, Cheshire; and about Ambleside and Grasmere. For other specimens I am indebted to Sir Oswald Mosley, Bart., of Rolleston Hall; and to Mr. Joseph Sidebotham, of Manchester.

It is in the following Catalogues:-Messrs. Veitch, of Chelsea; Rollisson, of Tooting; Sim, of Foot's Cray; Cutbush, of Highgate; Kennedy, of Covent Garden; Stansfield, of Todmorden; E. G. Henderson, of St. John's Wood; Cooling, of Derby; A. Henderson, of Pine-apple Place; and Young, of Taunton.

The illustration is from a plant in nuy own collection. 


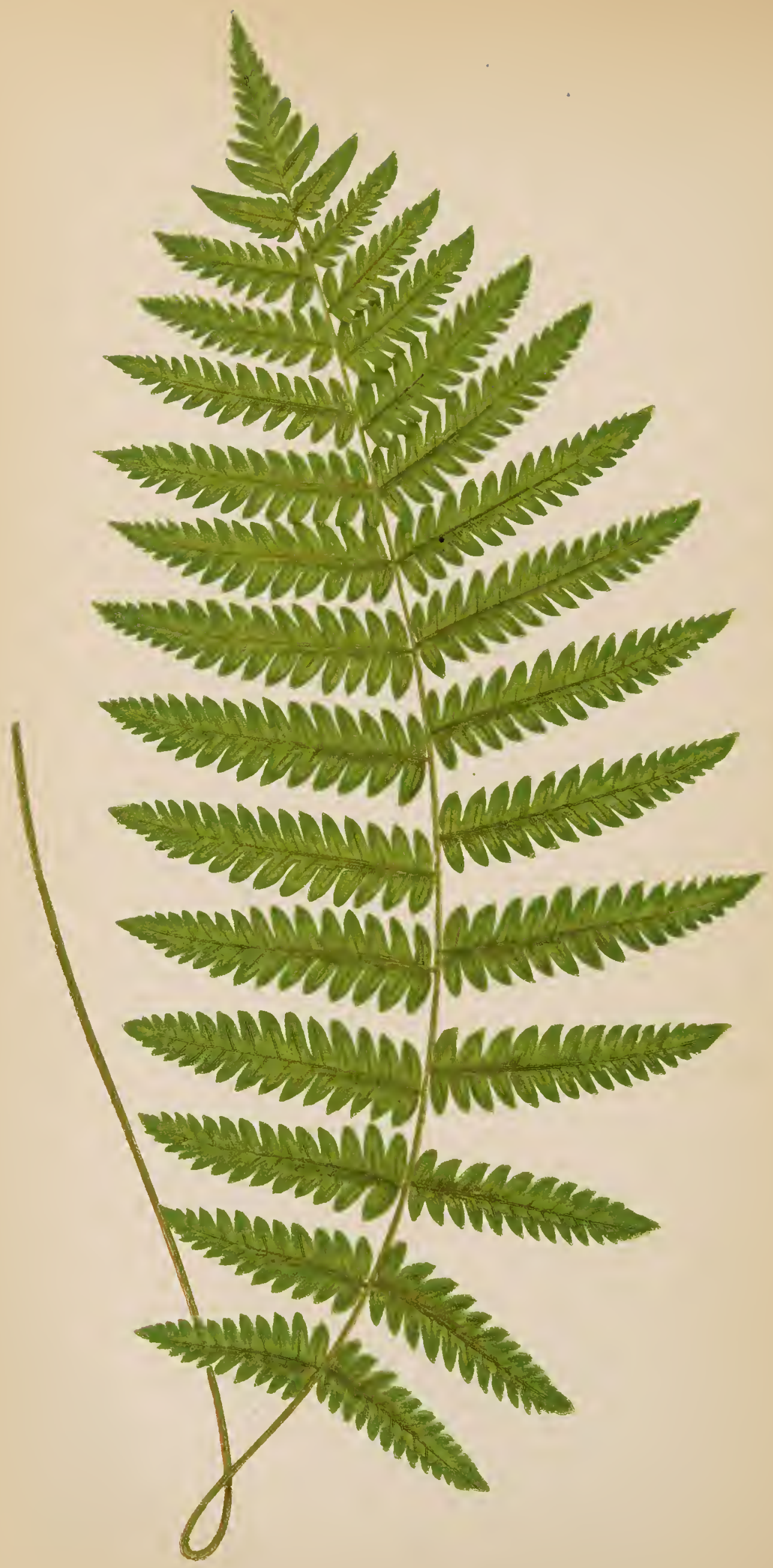

ASPIDILM THELYPTEIS, 


Portion of mature Frond, under side.

\section{ASPIDIUM THELYPTERIS.}

Swartz. Suith. Hooker and Arnott. Mackay. Schkuhr. Willdenow. Sprengel.

PI.ATE XVIIT. VOL. VI.

Lastrea thelypteris,

"6

Aspidium palustre, Acrostichum thelypteris, Polypodium thelypteris, " palustre,

Polystichum thelypteris, Nephrodium thelypteris, Athyrium thelypteris, Hemestheum thelypteris, Dryopteris thelypteris, Thelypteris palustris,

Aspidium-The Shield Fern. Thelypteris-Lady-Fern.
Presl. Deakin. Babington. Newman. Moore. Sowerby. GRAY.

Iinnteus. Bolton.

LINNAUS.

SAlisbury.

Roth.

STREMPEL.

Sprengel.

Newman.

GraY.

Sснотт.

\section{In the Section Lastrea of Authors.}

The Marsh or Female Buckler Fcrn is an interesting boggrowing species.

A widely-spread though local British Fern, less common in Ireland, and only found in one locality in Scotland, namely, 
Forfarshire. General throughout Europe, Algiers, Cape of Good Hope, New Zealand, Russian Asia, and North America.

Fronds lanceolate, membranaceous, erect; pinnate, pinnx numerous, spreading, linear-lanceolate, and deeply pinnatifid. 'The fertile fronds have the margins of their segments rerolute, are taller, and have a stouter stipes. Veins forked. Fructification extending over the whole under side of the frond.

Sori small, circular, and placed near the base of the venules. Indusium small and circular.

Stipes as long as the leafy portion of the fertile frond; smooth and round behind, channeled in front, near the base black and polished, above pale green.

Rachis smooth and circular behind, and channeled in front. Caudex creeping.

Length of frond from six to forty-eight inches; colour delicate green.

Easily cultivated in a damp situation with abundance of peaty soil.

This species I have procured wild from Oxton Bogs, and for other plants I am indebted to Sir Oswald Mosley, Bart., of Rolleston Hall, and for fronds to Mr. Norman, of Hull.

It is in the Catalogues of Messrs. Kennedy, of Covent Garden; Sim, of Foot's Cray; Rollisson, of Tooting; Cooling, of Derby; Teitch, of Chelsea; A. Henderson, of Pine-apple Place; E. G. Henderson, of St. John's Wood; Stansfield, of Todmorden; Young, of Taunton; and Cutbush, of Highgate.

The illustration is from a plant in my own collection. 


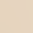






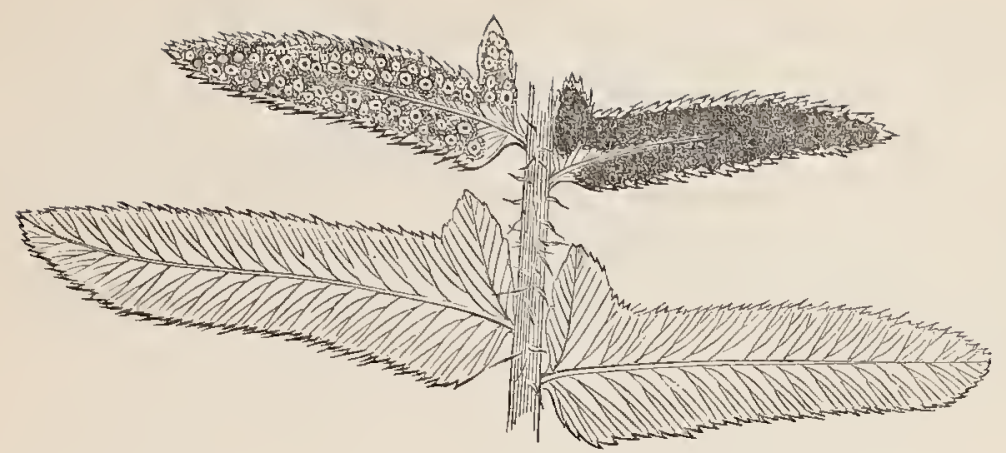

Portion of mature Frond, under side, shewing the highest barren and lowest fertile pinnæ.

\title{
ASPIDIUM ACROSTICHOIDES.
}

\author{
Swartz. Kunze.
}

PLATE XIX. VOL. Yr.

\author{
Polystichum acrostichoides, \\ or \\ 66 \\ Aspidium auriculatum, \\ Nephrodium acrostichoides,
}

Schotr. Moore \& Houlston. Swartz. Schkumr. Sмтtн. Willdenow. Link. Prest. SCHKUHR.

Michaux.

Aspidium-The Shield Fern.

Acrostichoides-...........?

A Pleasing hardy Fern, easily cultivated, and very dissimilar from all other species.

Native of North America.

First introduced into the Royal Gardens, Kew, in 1820.

Fronds pinnate, lanceolate; apex contracted where soriferous. Pinnæ oblong-linear, acute, petiolate, auriculate on the upper base, lower base obliquely truncate; margin ciliato-serrate, with lengthy spinulous hairs.

Rachis and stipes squamulous. Terminal, being adherent to a tufted rhizoma.

Sori confluent. 
Length of frond two feet; colour dull green.

For plants of this species I am indebted to Mr. R. Sim, of Foot's Cray; and for fronds to Mr. Norman, of Hull.

It is in the Catalogues of Messrs. Young, of Taunton; A. Henderson, of Pine-apple Place; Stansfield, of Todmorden; Kennedy, of Covent Garden; Cooling, of Derby; Cutbush, of Highgate; Sim, of Foot's Cray; Rollisson, of Tooting; and Veitch, of Chelsea.

The illustration is from a plant in my own collection. 






Portion of mature Frond, under side.

\section{ASPIDIUM CRISTATUM.}

Swartz. J. E. Smith. Hooker and Arnott. Schikuhr. Willdenow. Sprengel.

PIATE XX. VOL. VI.

Aspidium cristatum var. callipteris, Aspidium Goldieanum,

Aspidium lancastriense, Lastrea cristata,

" callipteris,

Polypodium cristatum, " callipteris,

Nephrodium cristatum, Polystichum cristatum, " callipteris, Lophodium callipleris, Doryopteris cristata, Lastrea cristata $\}$ var. uliginosa,

Lastrea uliginosa, Aspidium spinulosum,

" $\quad$ " $\quad$ "uliginosum, $\}$

Lophodium uliginosum,

\section{Pursir.}

Of SOME GaRdens, (not of HoOKER aND Greville.)

Sprengel. Schkutr. Willdenow.

Preșl. Deakis. Moore.

Babington. Newman. Sowerby.

Newaian.

LINNAUS.

EHrhart.

Mrchaux.

Rотн.

De Candolle.

Newman.

GraY.

Moore.

Babington.

Newman.

HoOkER \&

AnNot'.

The var. uliginosum.

BraUn.

NETIIAN.

Aspidium_The Shield Fern.

Cristatum-Crested. 


\section{In the Section Lastrea of Authors.}

The Crested Buckler Fern is a very local and at the samc time singular and beautiful species. It is upright in habit, having a long narrow frond, with large bold fructification, which is almost black soon after the indusium has been shed. It is a difficult Fern to grow, owing to its native habitat being a boggy situation. When in cultivation as an out-door Fern if planted in peaty soil near water it will flourish as well as when growing wild, but in less favourable situations it will become wcaker every year, until it finally, in two or thrce years, dies. In its native situations it appears to prefer growing on the sides of large tufts of Aira caspitosa and other swampy grasses.

Botanists secm of opinion that another upright-growing Fern constantly found amongst it is merely a variety, yet from a vast number of examples that I have examined, the distinctive differences are so great that it seems more natural to separatc them. Indeed the so-called variety uliginosum will flourish in an open Fernery in situations which would prove fatal to Ehrhart's Fern. It also ripens its fructification earlier in the summer, and the fronds fade away in autumn, shrivelling up in a similar manner to what is observed with the Lady Fern, whilst $A s$ pidium cristatum remains green far into winter, and the fronds do not shrivcl up, breaking near the ground, and thus causing them to be prostrate beforc they have fadcd away.

A hardy deciduous species indigenous to Great Britain, growing in boggy situations in Norfolk, Suffolk, Nottinghamshire, and Cheshire. Generally dispersed throughout Europe and North America.

Frond upright, narrow, linear-oblong, tapering at the apex, sub-bipinnate. Pinnæ numerous, and broadly triangular ncar the basc, being more clongate near the centre of the frond. Pinnulcs blunt, adnate; basal lobes scrrate, the rest inciso-crenate, except at the apex.

Veins forked.

Fructification usually occupying the upper half of the frond.

Sori circular, numcrous, indusiate, and medial. Indusium reniform, flat, and membrawous. 
Length of frond from one to three fcet; colour heavy green.

Lastrea uliginosa of Newman, will, in all probability, be raised to the rank of a species when better known. It bears its fertile fronds long before $A$. cristatum; the latter are ripe about the last week in July, whilst $A$. uliginosum becomes ripe in June. The fronds have morc the character of A. spinulosum than of $A$. cristatum; they grow upright, and are naked for nearly half their length, the pinnules are smaller and more numerous, and the fructification extends over the whole under side of the frond. Through the kindness of Mr. Henry Sherbrook, of Oxton, I have been enabled to cxamine the plants in their native habitat of Nottinghamshire, namely, Oxton Bogs, and also to bring away with me a series of plants of both forms, and although both flourish best in a moist situation in peaty soil, still A. uliginosum will grow in a much dricr situation than $A$. cristatum, and is an casier plant to grow under pot-culture.

For plants of a varicty of this Fern from North Amcrica, known as the Lastrea cristata-major, I am indebted to Mr. R. Sim, of Foot's Cray.

It is in the Fern Catalogues of Messrs. Young, of Taunton; Bass and Brown, of Sudbury; A. Henderson, of Pine-apple Place; E. G. Henderson, of St. John's Wood; Stansfield and Son, of Todmorden; Cooling, of Derby; Pcarson, of Chilwell; Kennedy, of Covent Garden; Cutbush, of Highgate; Sim, of Foot's Cray; Rollisson, of Tooting; and Veitch, Jun., of Chelsea.

The illustration is from a plant in my own collection. 


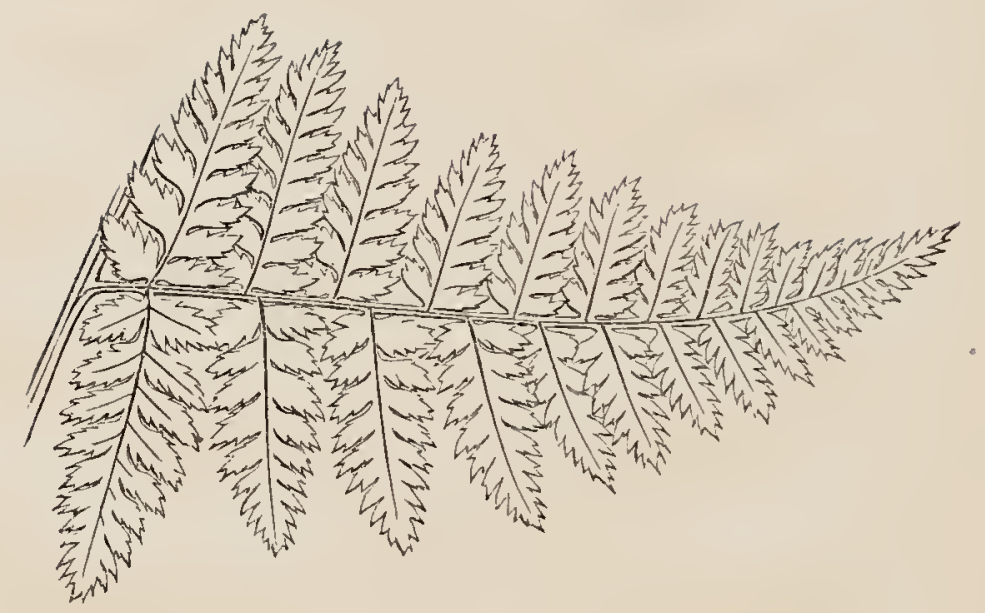

Aspidium cristatum.-Tariety Uliginosum. 



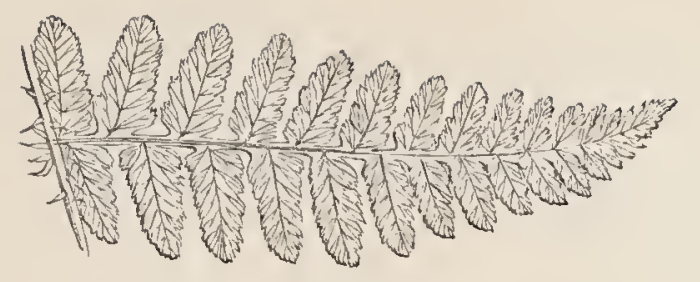

Portion of mature Frond, upper side.

\section{ASPIDIUM RIGIDUM.}

Sirartz. Schkuhr. Hooker and Arnott. Willdevow. Sprengel.

PLATE XXI. VOL. VI.

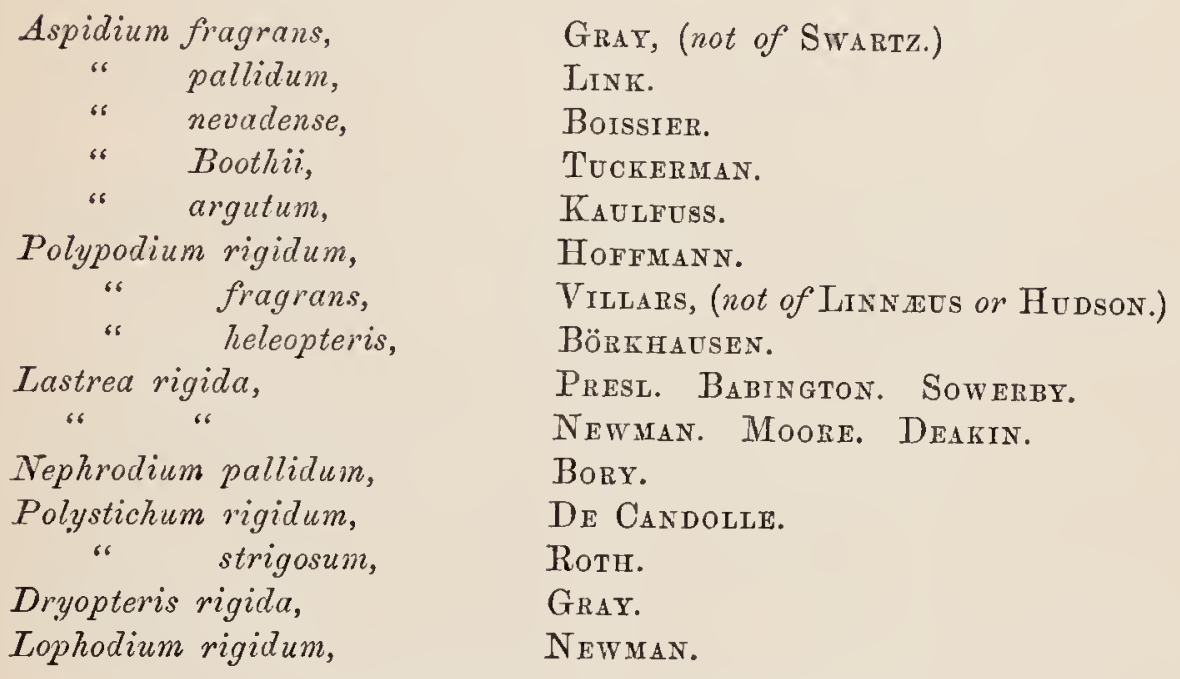

Aspidium-The Shield Fern. Rigidum-Rigid.

In the Section Lastrea of Authors.

The Rigid Shield Fern, or, as Mr. Moore has now called it, the "Rigid Buckler Fern," is a pretty hardy, deciduous British 
species, easily grown both in a Fernery and under pot-culture.

A local spccies, confined to the limestone mountains of W $W$ estmorland, Lancaster, and York, and even in these localities extending over a small arca. In Ireland it has been found in the county of Louth. In England Mr. Moore remarks that it ranges between twelve and fifteen hundred feet above the sea-level.

It is a native of France, Switzerland, Sardinia, Sicily, Calabria, Germany, Dalmatia, Croatia, Hungary, Morea, Siberia, Asia Minor, California, and Massachusetts; in the two latter countries it attains a larger size.

The caudex is thick, tufted, scaly, and decumbent. Stipes short, densely scaly. Rachis scaly. Venation branched. Fronds bipinnate, triangularly elongate. Pinnæ alternate, triangular in form. Pinnules oblong, base truncate, apex obtuse. Length from one to two feet; colour dull green, paler on the under side. Numerous minute glands are scattered over the frond, giving it a somewhat glaucous appearance.

There arc no permanent varieties of this species.

The Asplenium rigidum is readily recognised from $A$. Filixmas, by its more rigid habit, and by the dusty look of its fronds and their less size.

For plants of $A$. rigidum I am indebted to Mr. Joseph Sidebotham, of Manchester; Mr. Wraight, of Newlands; Mr. Clapham, of Scarbro'; and Mr. Clarke, gardener to Mr. Wilkinson Dent, of Flass House, Crosby Ravensworth, Westmorland; to Mr. Clarke my obligations are more particularly due for an extensive scries of specimens of this species, gathered in his neighbourhood.

This Fern may be procured of the following Nurserymen:W. Cutbush, of Highgate; J. Young, of Taunton; Veitch, of Chelsea; A. Henderson, of Pine-apple Place; E. G. Henderson, of St. John's Wood; R. Sim, of Foot's Cray; A. Stansfield, of Todmorden; E. Cooling, of Derby; J. Pearson, of Chilwell; IV. Rollisson, of Tooting; and R. Kennedy, of Covent Garden.

lhe illustration is from a plant in my own collection. 





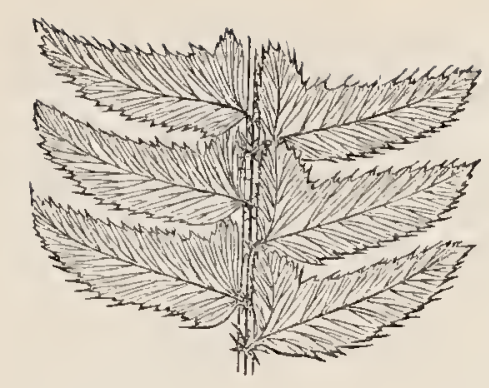

Portion of mature Frond, upper side.

\section{ASPIDIUM LONCHITIS.}

Swartz. J. E. Suitil. Hooker and Arnott. Mackay. Schikuhr. Willdenow. Sprengel.

PLATE XXII, VOL. VI.

Aspiclium asperum, Polystichum lonchitis, " "

" "

Polypodium lonchitis,

Aspidium-The Shield Fern.
Gray.

Roth. Deakin. Babington.

Sowerby. Newman. Moore.

Prest. Fee.

Linnzeds. J. E. Smitir. Bolton.

In the Section Polystichum of Authors.

The "Holly Fern," or, as it is sometimes called, the "Alpine Shield Fern," is a mountain plant, and difficult to cultivate. It has a range of from about the elevation of one thousand two hundred to more than three thousand feet. A British species, found only in Yorkshire on Ingleborough; in the Lake district; Carnarvonshire; on the mountains of the Highlands in Scotland; and in Ireland in the counties of Kerry, Meath, Sligo, Leitrim, and Donegal. It occurs in Iceland, Lapland, Sweden, Denmark, Russia, Germany, Hungary, Eng- 
land, Scotland, Ireland, Wales, France, Switzerland, Italy, Spain, Greece, Russian Asia, Kamtschatka, and the Rocky Mountains in North-west America.

A hardy evergreen species.

Fronds pinnate, of a narrow linear-lanceolate form, and rigid, the pinnæ being falcately lanceolate, acute, spinulosely serrate. Pinnæ numerous and undivided, and on the under side have many small hirsute scales.

Fructification mostly on the upper half of the frond. Sori large, circular, and crowded, eventually becoming confluent. Indusium orbicular and membranaceous.

Stipes short, varying from half an inch to three inches in length, covered with brown chaffy scales. Rachis densely scaly.

Length of frond from six to twenty-four inches, usually from twelve to fifteen inches; colour deep green above, paler beneath.

Mr. Wollaston describes two varieties:-

Multifidum, having the apex divided. Not constant in cultivation.

Proliferum, producing small bulbils in the axils of the lowermost pinnæ.

For plants of this species I am indebted to Mr. Clapham, of Scarbro', and to Miss Barker, of Beeston; and for fronds to Mr. J. Pearson, of Chilwell.

It is in the Catalogues of Messrs. Pearson, of Chilwell; Young, of Taunton; Bass and Brown, of Sudbury; A. Henderson, of Pine-apple Place; F. G. Henderson, of St. John's Wood; Rollisson, of Tooting; Sim, of Foot's Cray; Veitch, of Chelsea; Stansfield, of Todmorden; and Kennedy, of Covent Garden.

The specimens for illustration were kindly given me by $\mathrm{Mr}$. John Pearson, of Chilwell. 


\section{•}











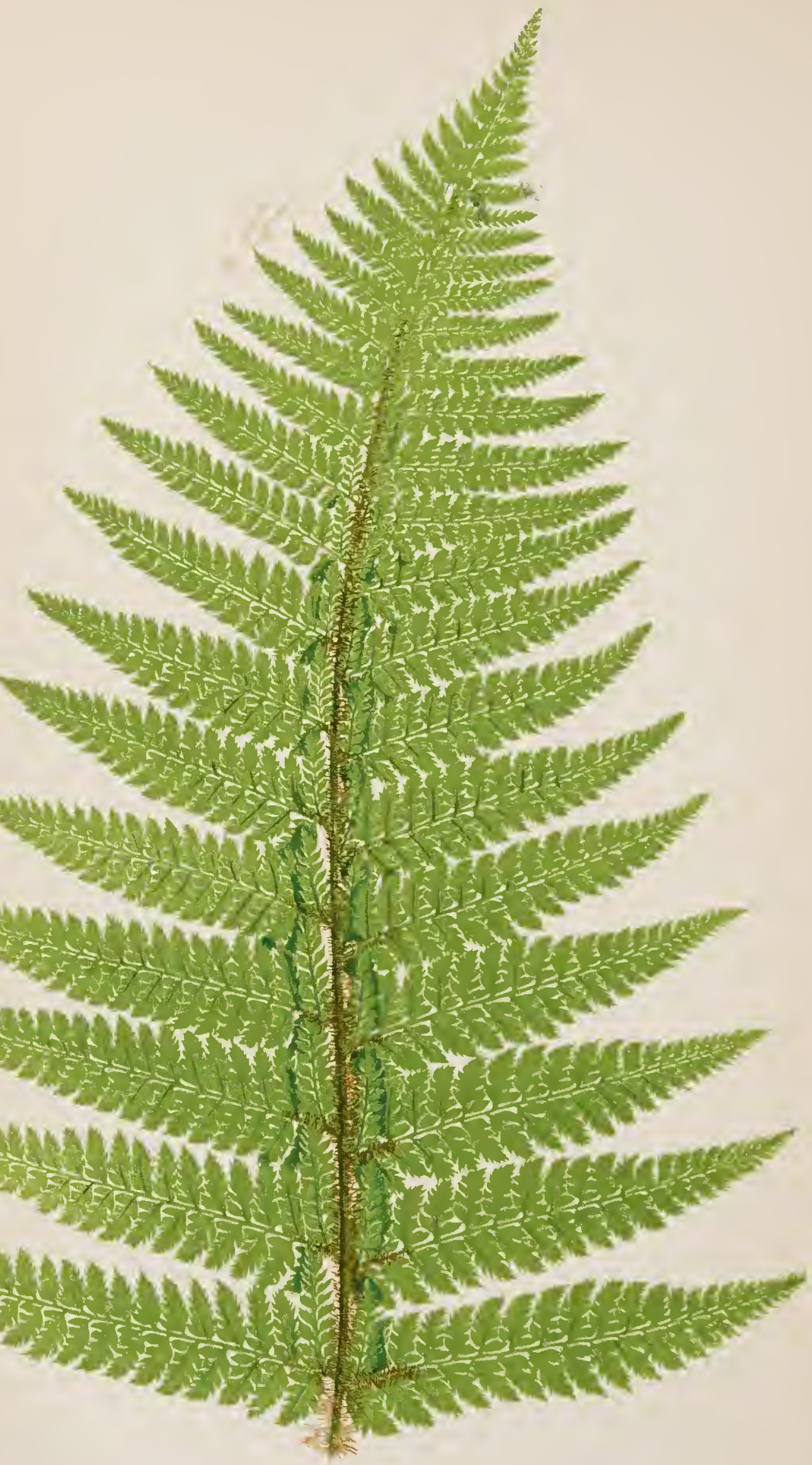

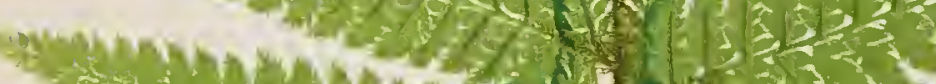

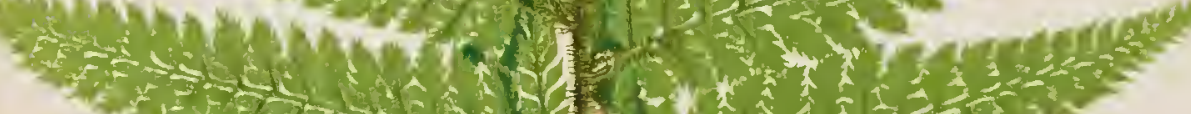

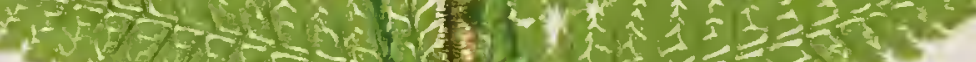



Portion of mature Frond, under side.

\section{ASPIDIUM ANGULARE.}

Kitaibel. J. E. Shith. Sowerby. Machay. HoOKer AND ARNOTT.

PLATES XXII AND XXIV. VOL. VI.

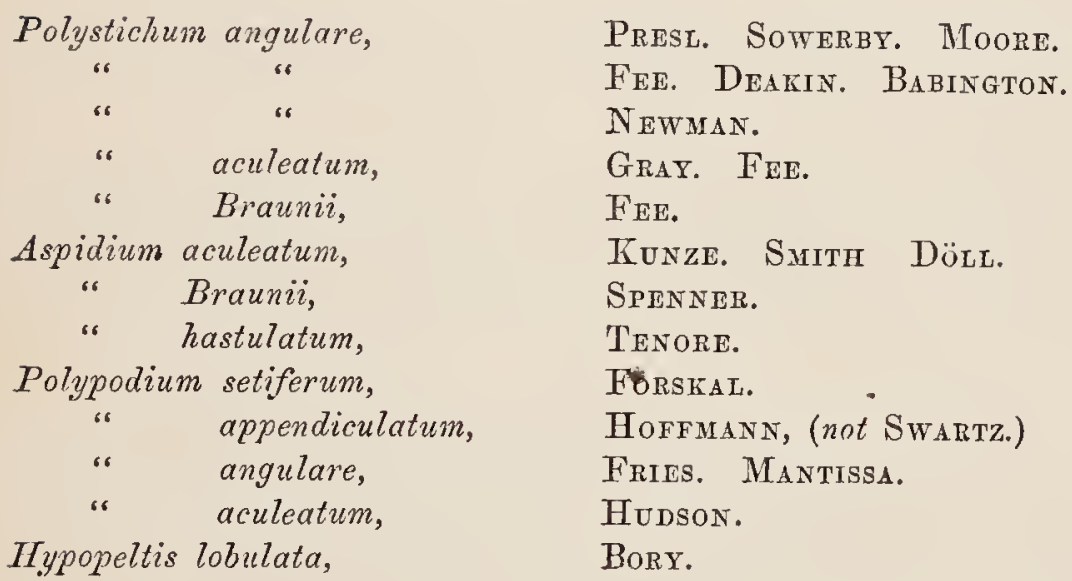

Aspidium-The Shietd Fern. Angulare-An angle.

In the Section Polystichum of Authors.

As exccedingly beautiful species, growing in shady wooded localities, tolerably abundant throughout England, Wales, and 
Ireland. Rare in Scotland. It is known as the "Soft Prickly Shield Fern."

A hardy species, easily cultivated.

Closely allied to Aspidium aculeatum, but having characters sufficiently distinct to keep them divided.

Found in Sweden, Norway, Scotland, Ireland, England, Wales, Jersey, Germany, France, Belgium, Spain, Italy, Greece, Coast of the Black Sea, Asia, India, Madeira, Canary Islands, Azores, Abyssinia, African Coast of the Mediterranean, Natal, United States, Sitka, Guatemala, Mexico, Caraccas, and New Granada.

Fronds bipinnate or tripinnate, with numerous nearly linear pinnæ, broadest at the base, and tapering gradually to the apex; alternate. Pinnules ovate-falcate, with an anterior auricle, serrated deeply on the margins. Beneath the pinnules there are hair-like scales. Veins two or three times branched.

Length of frond from two to five feet; width from seven to ten inches; brilliant green above, paler beneath.

Fronds spreading, and arranged in a circlet around the crown.

Stipes from four to eight inches long, densely scaly. Rachis prominent, slightly channeled above, and rounded beneath, and covered with hair-like scales.

Sori small, numerous, circular, indusiate, occupying the upper two thirds of the frond. Indusium orbicular, membranaceous.

There are many varieties of $A$. angulare. The following are enumerated in Mr. Moore's excellent work, "The Natureprinted Ferns:" -

1.-Hastulatum, Moore. Found near St. Martha"s Hill, Surrey. It is known by the small size of the acute pinnules, and their distinct and slender footstalks.

2.-Acutum, Wollaston. Found in Sussex and Hampshire. Pinnules rather longer than in hastulatum, narrow, falcate, and strongly auricled. It approaches the normal form of $A$. aculeatum.

3.-Aristatum, Wollaston. Found in Sussex by Mr. Wollaston. The points of the serratures are aristate, and the long hair-like points give the plant a bristly appearance. It bears bulbils on the stipes.

4.-Multifidum, Wollaston. Apex of frond tufted, and the pinnæ sometimes divided. 
5.-Proliferum, Wollaston. Found at Wimbledon, by Mr. Choules, and near Ottery St. Mary, Devonshire, by Mr. Wollaston. Known in cultivation as angustatum. Proliferous, bearing bulbils at the point of junction of the pinnæ with the rachis, and occasionally in the axils of the pinnulcs. 'Tripinnate, pinnules narrow and attenuated, and conspicuously stalked, deeply cleft, and lobes widely separated. Vcry handsome.

6.-Depauperatum, Wollaston. Found by Dr. Kinahan in Ireland. Fronds frequently merc skcletons; it occasionally produces bulbils.

7.-Intermedium, Wollaston. Found near St. Mary's Cray, Kent, by Mr. Robert Sim. It very closely resembles $A$. aculeatum.

8.-Pramorsum, Allchin. Found in Ireland by Dr. Allchin. Dwarf, pinnæ laciniate and irregular.

9.-Dissimile, Moore. Found in Kent by Mrs. Delves. Pinnæ irregular.

10.-Irregulare, Moore. Found ncar Nettlecombe, Somersetshire, by Mr. Elwerthy, gardencr to Sir W. C. Trevelyan, Bart. Pinnæ very irregular. The lower pinnæ have unequally inciso-lobate pinnules.

11.-Biserratum, Moore. Found near Brentford by Mr. S. F. Gray; also common in Jersey. Long stipes. A lax form, with large broad pinnule, inciso-serrate; all but the anterior lobe biserrate and aristate.

12.-Alatum, Moore. Found in Somersetshire by Mrs. A. Thompson. Pinnules connected by a wing on both sides the secondary rachides, on which they are dccurrent. Pinnules more tapering.

13.-Imbricatum, Moore. Distinct and graceful. Frond two feet in length, linear-lanceolate, in habit resembling A. lobatum. Pinnæ short; apices blunt; pinnules crowded, blunt, and imbricated. A bulbil is found on the larger fronds, on the stipes beneath the soil, and therefore each large frond is accompanied by a small one. Found in Somersetshire by Mr. Elworthy.

14.-Incisum, Wollaston. Discovered in Sussex by Mr. Wollaston and Dr. Allchin. Grows four feet in length. Pinnules very dissimilar in size and shape.

15.-Subtripinnatum, Moore. Lowcr pinnules very deeply pinnatifid. A common variety.

TOL. VI. 
16.-Tripinnatum, Moore. The present Fern the author reccived as a seedling plant from Mr. R. T. Millett, of Penzance. Mr. Moore, in his "Nature-printed Ferns," says of it, "This very beautiful and peculiar variety has been called tripinnatum, in contrast with the subtripinnatum, in consequence of its basal anterior pinnules being much more distinctly pinnate, though the plant is on the whole less divided than the Devon form of the variety proliferum, or the Irish variety decompositum. The most remarkable peculiarity is the unusual elongation of the antcrior basal pinnules, and their truly pinnate character; the little pinnulets being distinctly stalked. The other pinnules are highly developed, though less so than the basal one, and they are crowded and imbricated. It is profuse in the production of sori, and thickly covered with subulate scales. It was found in Cornwall by Mr. Millett, and was first made known to cultivators by Mr. E. J. Lowe. It is a very marked aberration from the normal form, and appears to be very rare." Another charactcr of this Fern, not visible in a dried frond forwarded to Mr. Moore, is strikingly exhibited in the growing plant; the pinnæ, instead of being flat, and lying in the same plane with the stipes and rachis, are almost at right-angles to this line, lying in a horizontal position above each other,-Plate XXIV.

17.-Decompositum, Moore. This beautiful variety is by far the most compound or divided form. An Irish Fern, cultivated in the Glasnevin Botanic Gardens.

For a more lengthy description the reader is referred to Mr. Moorc's "Nature-printed Ferns."

I have procured this species wild at Matlock; Chaigeley, Lancashire; and at Ambleside. For plants from Cornwall I am indebted to Mr. R. T. Millet, of Penzance. Sir Oswald Mosley, Bart., has sent me specimens of several varieties; Mr. R. T. Millet the beautiful variety tripinnatum, (of which a colourcd plate is here given;) Messrs. Rollisson the variety proliferum. For fronds I am indebted to Mrs. Delves, of Tunbridge Wells; Mcssrs. Rollisson, of Tooting; Sir Oswald Mosley; Mr. Sim, of Foot's Cray; and Mr. Norman, of Hull.

'This species can be procured of any Nurseryman. The following varieties are in the aftcr-montioned Catalogues:-

Subtripinnatum, proliferum, imbricatum, dissimile, and inter- 
medium, R. Sim, of Foot's Cray. Subtripinnatum and proliferum, Kennedy, of Covent Gardcn. Angustatum, biserratum, and proliferum, Veitch, of Chclsea. Proliforum, A. Henderson, of Pine-apple Place. Aristatum, Stansfield, of Todmorden. Proliferum, Young, of Taunton.

The illustrations are from plants in my own collection.

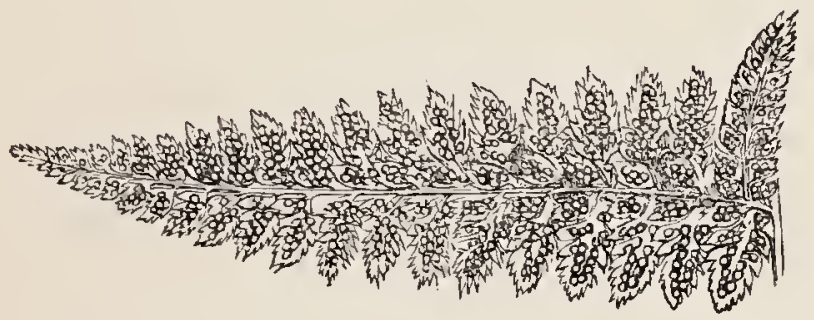

Vuriety Tripinnatum. Pinna of mature Frond, under side.

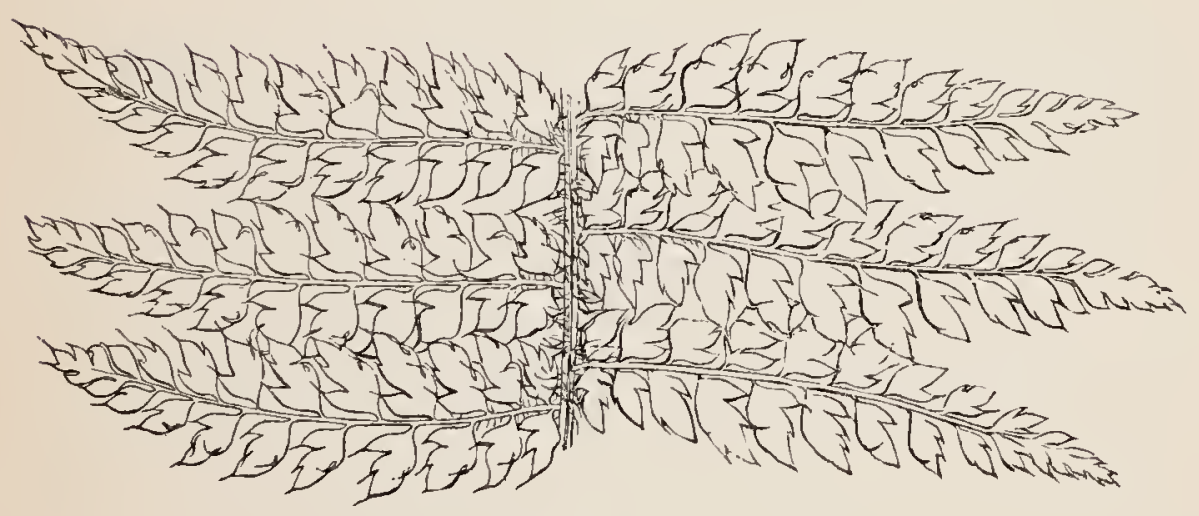

Variety Proliferum. 



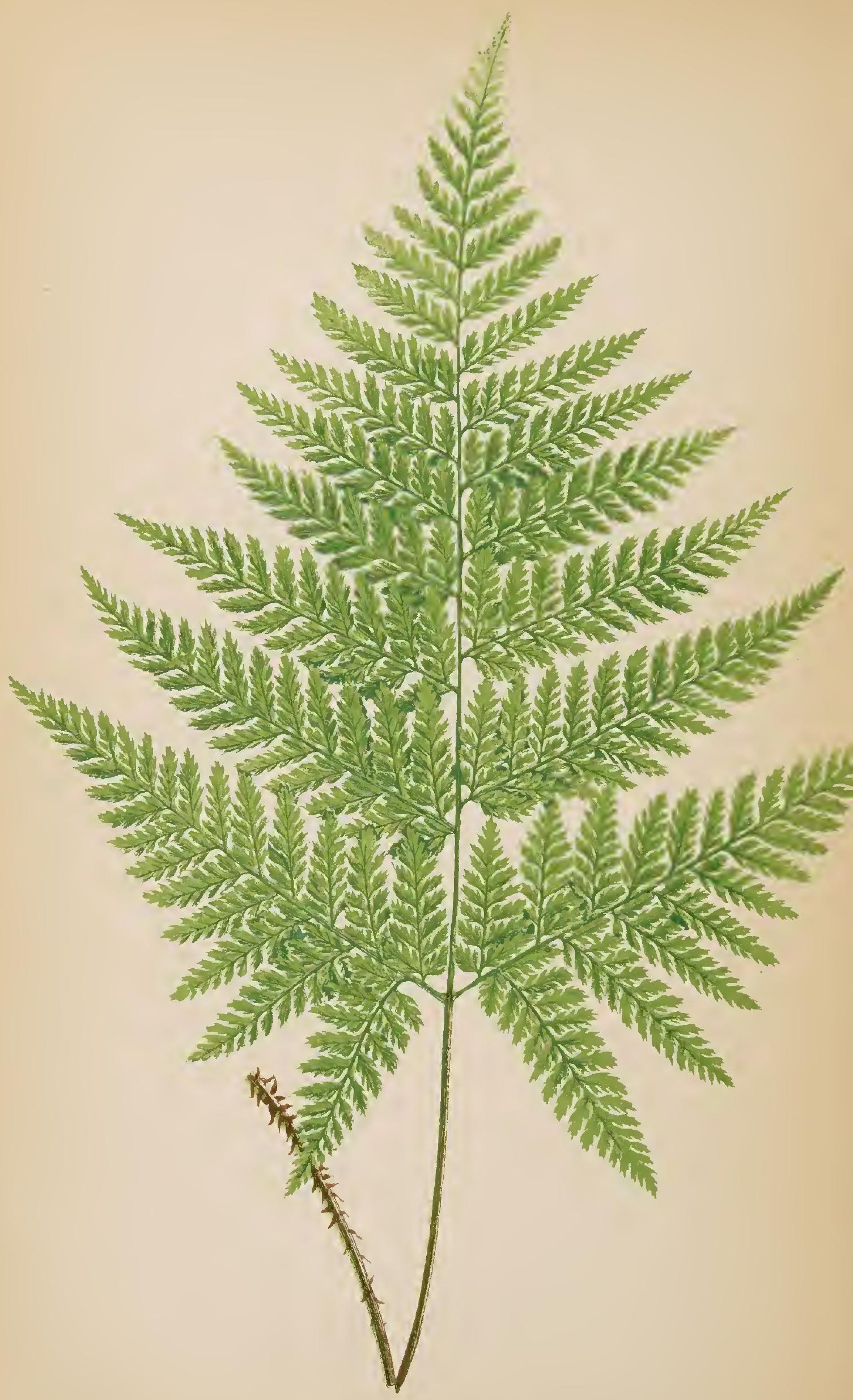




$$
\text { . }
$$







Portion of pinna of mature Frond, under side.

\title{
ASPIDIUM PUBESCENS.
}

Swartz. Sprengel. Fee.

PLATE XXV. VOL. VI.

\author{
Lastrea pubescens, \\ " 6 \\ Presl. J. Syith. \\ Polypodium pubescens, \\ Nephrodium pubescens, \\ MoORE AND HOULSTON. \\ LinNeUs. \\ Hooker and Greville. \\ Aspidium-The Shield Fern. \\ Pubescens-Downy.
}

In the Section Lastrea of Authors.

Aspidium pubescens is often confused in gardens with the $A$. decompositum, which is a similar-looking species, although destitute of that downy character so conspicuously shewn in the A. pubescens.

A handsome evergreen stove species, capable of being grown VoL VI. 
into a splendid specimen, and requiring no particular care in its cultivation.

Native of Jamaica.

Fronds deltoid, pubescent, sub-tripinnate; pinnules oblonglinear; segments sharply toothed, largest on the superior side.

Stipes covered with scales of a brown colour, being most crowded near the base; lateral, adherent to a slender, creeping, scaly rhizoma.

Sori medial, at first very pale straw-coloured.

Length twelve inches.

For plants I am indebted to Messrs. Booth and Son, of Hamburg.

It is in the Catalogues of Messrs. Sim, of Foot's Cray; Veitch, of Chelsea; Rollisson, of Tooting; Masters, of Canterbury; Booth and Son, of Hamburg; Stansfield, of Todmorden; and Cooling, of Derby.

The illustration is from a plant in my own collection. 


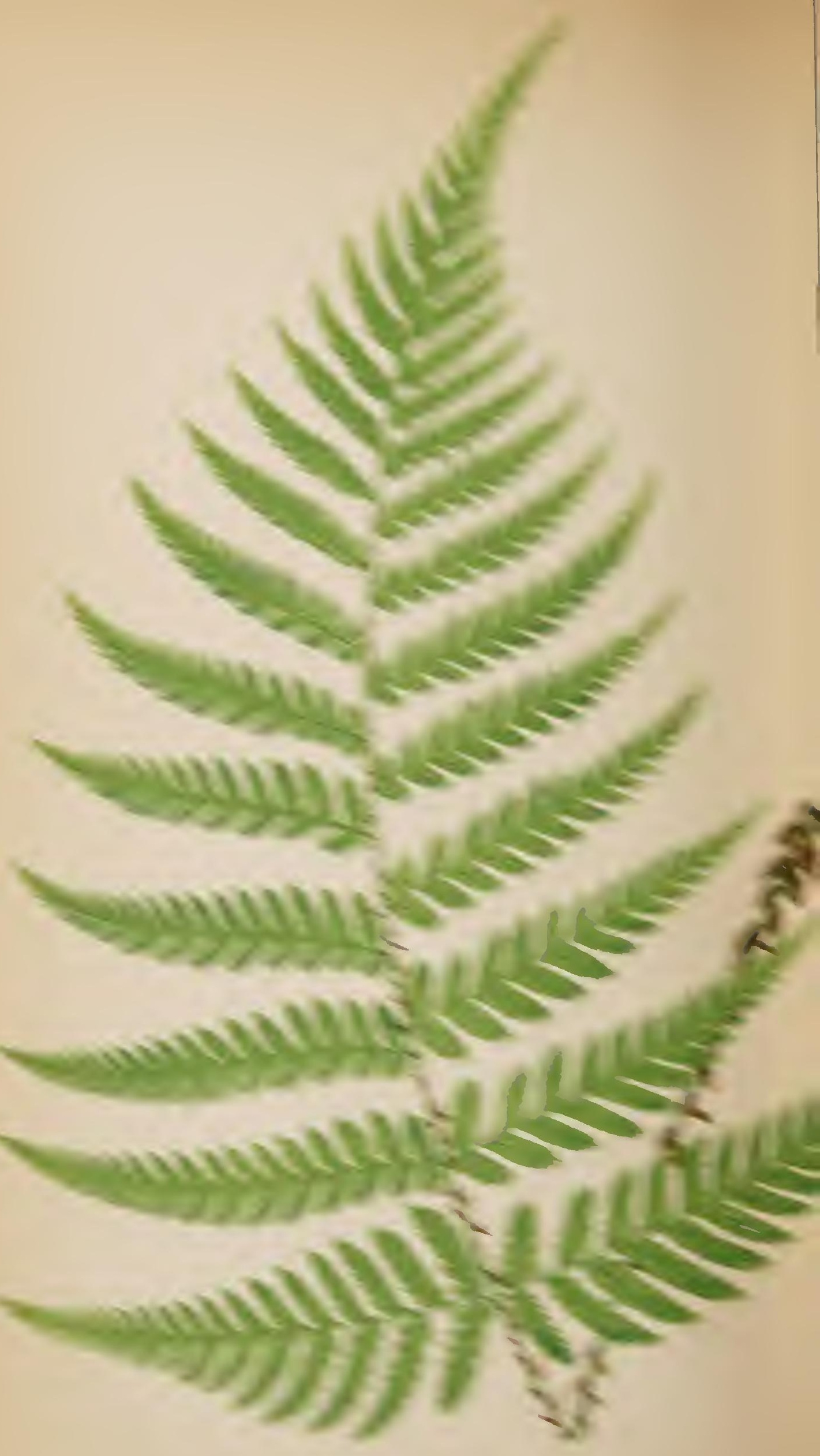





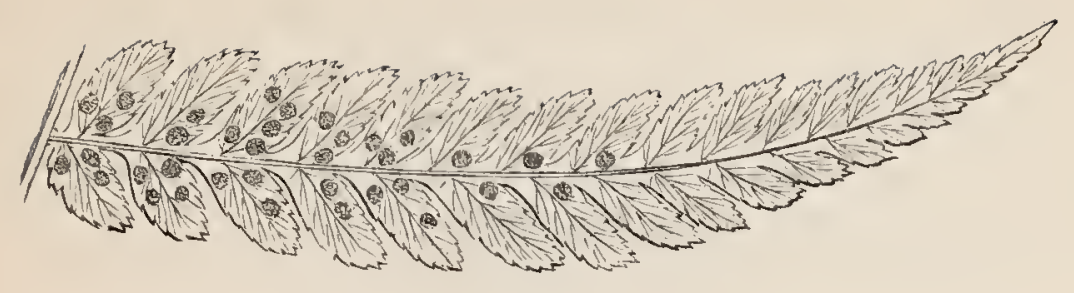

Pinna, under side.

\section{ASPIDIUM ELONGATUM.}

Swartz. Hooker and Greville. Fee. Sprengel. Kunze.

PLATE XXVI. VOL. VI.

\author{
Aspidium oligodonton, \\ Lastrea elongata, \\ 6 \\ Polypodium elongatum,
}

Aspidium-The Shield Fern.

\author{
Desvaux. \\ Presl. J. Sмith. \\ Moore and Houlston. \\ Aiton.
}

This interesting Fern is not very dissimilar to an elongated form of Aspidium filix-mas, and may prove hardy in warm situations.

A greenhouse species.

Native of the Island of Madeira, Canary Island, Azores, and Teneriffe.

Introduced into England in the year 1799.

Fronds glabrous, triangularly elongate in form, sub-tripinnatc; the pinnæ triangularly-elongate. Pinnules oblong-acute, with slightly dentate blunt segments. Stipes paleaceous. Terminal, adherent to a thick, short, crceping rhizoma.

Sori medial. 
Length of frond from two to three feet; colour deep green. For a plant of this species I am indebted to Mr. R. Sim, of Foot's Cray.

It is in the Catalogues of Messrs. A. Henderson, of Pineapple Place; Sim, of Foot's Cray; Stansfield, of Todmorden; and Booth and Son, of Hamburg.

The illustration is from a plant in my own collection. 











Portion of pinna of mature Frond, under side.

\section{ASPIDIUM DILATATUM.}

Smith. Swartz.

PIATE XXYII, VOL, VI.

Lastrea dilatata,

" "

"6

Aspidium spinulosum,
"
"،
" erosum,

Lastrea multiflora,

Polypodium dilatatum,

" cristatum,

"s multiflorum,

Polystichum multiflorum,

"spinulosum,

" dilatatum,

Dryopteris dilatata,

Lophodium multiflorum,

Lastrea dilatata,

" multiflora var. dilatata,
Presl. Lindley and Moore.

Smith. Babington. Sowerby.

Moore.

Schkuhr. Swartz. Willdenow.

Hooker and ArnotT.

SCHKUHR.

Newman. Deakin.

HoF MaNN.

Hudson. Hoffmann. Bolton.

RotH.

Roth.

De Candolle.

De Candolle.

Gray.

NeWMaN.

Moore.

\} DEAKIN.

$\left\{\begin{array}{c}\text { Varicty } \\ \text { Tunacetifolium. }\end{array}\right.$ 




Aspidium-The Shield Fern. Dilatatum-Extended.

In the Section Lastrea of Authors.

A specres subject to great variety. Aspidium dilatatum, the "Broad Prickly-toothed Buckler Fern," is a noble British species; easily cultivated, and of large growth.

A hardy deciduous Fern, growing in shady situations, and to be met with almost everywhere. The variety tanacetifolium is also common; the other varieties are local.

It is dispersed throughout the whole of Europe, from Lapland to Portugal and Spain. In Asia, in Kamtschatka; in 
Africa, in the Azores; in America, at Sitka, Port Mulgrave, Canada, and the Rocky Mountains.

The ordinary form is ovate-lanceolate; bipinnate to tripinnate. Pinnæ opposite, numerous, the basal pair obliquely triangularelongate; the posterior pinnules considerably larger than the anterior pinnules. The pinnæ taper gradually from the base to the apex. Pinnules ovate-oblong, rather acute, the basal ones stalked, and the upper pinnules sessile and decurrent, the lower ones deeply pinnatifid, occasionally pinnate. The divisions are all sharply dentate, ending in a bristle-like point.

Veins forked.

Caudex stout, mostly upright; crown densely scaly.

Stipes terminal, from a third to half the length of the frond; densely scaly.

Fructification occupying the whole of the under side of the frond. Sori numerous, circular, and indusiate. Indusium reniform and membranous.

Length from two to six feet, usual size from two to three feet; breadth from six to sixteen inches. Colour dark green above, paler beneath.

One of the most difficult species to understand, as in its different forms it approaches both $A$. fanisecii and $A$. spinulosum; from the latter it is known by $A$. spinulosum having a creeping caudex, the few broad pallid scales of its stipes, and by the indusium being entire.

The form tanacetifolium, or "Tansy-leaved prickly-toothed Buckler Fern," is tripinnate, with broad fronds; stipes having numerous entire dark brown scales, with a darker bar down the centre; lanceolate in form.

The form nanum, or "Dwarf prickly-toothed Buckler Fern," from Settle and Ilfracombe, is always dwarf, varying from two to ten inches in length.

The form dumetorum, or "Thicket prickly-toothed Buckler Fern," is also dwarf, with broad frond, having large abundant fructification, and is remarkable for the glandular surface of the fronds.

The form collinum, the "ITill prickly-toothed Buckler Fern," known also as "Pinder's Fern," has the pinne distant and spreading. 
'The form Chanterise, "Mrs. Chanter's prickly-toothed Buckler Fern," differs in the narrowed form and attenuated apex of its fronds.

The form angustatum, the "Linear prickly-toothed Buckler Fern," has narrow lanceolate bipinnate fronds. It very closely approaches $A$. spinulosum.

The form alpinum, the "Alpine prickly-toothed Buckler Fern," another form approaching A. spinulosum; common on Ben Lawers.

The form glandulosum, the "Glandular prickly-toothed Buckler Fern," is large and erect in habit.

It would be impossible to describe the endless variety of this very variable species. Mr. Moore, in his "Nature-printed Ferns," gives the following as the most distinct of the varieties of A. dilatatum, (the Lastrea dilatata of most authors.)

1.-Multifida, Wollaston. Rachis divided low down, so as to make two fronds on one stipes. Not constant in cultivation.

2.-Tanacetifolia, Moore. Broad tripinnate triangular frond.

3.-Pumila, Moore. Small sub-deltoid bipinnate variety, with pallid scales. A local Fern from Hampstead, Dumbartonshire, Carnarvonshire, Bute, and mountains of Dublin and Wicklow.

4.-Dcltoidea, Moore. An elegant variety, with deltoid tripinnate finely-cut fronds. Found in Devonshire by the Rev. J. M. Chanter.

5.-Fuscipes, Moore. Fronds nearly as broad as long, tripinnate, the points of the fronds and pinnæ caudate. Found in Guernsey by Mr. G. Wolsey.

6.-Micromera, Moore. Finely divided, though small it is almost quadripinnate. Found near Ilfracombe by the Rev. J. M. Chanter.

7.-Nana, Newman. Fronds ovate, bipinnate, and very dwarf. From Settle and Ilfracombe.

8.-Dumetorum, Moore. Dwarf, fronds ovate; stipes and rachis clothed with glands, as well as the under side of the frond.

9.-Collina, Newman. Somewhat similar to dumentorum, but almost destitute of the glands so conspicuous in that variety.

10.-Smithii, Moore. An Irish plant, somewhat related to collina. 
11.-Chanterice, Moore. Erect, with the pinnæ twisted upwards.

12.-Distans, Moore. Larger than Chanterice, but somewhat allied to that variety. Found at Coombe Wood, Surrey, by Mr. S. F. Gray.

13.-Obtusa, Moore. A distinct variety, with narrow ovate fronds, having oblong-obtuse, shallow, lobed pinnules. From Middlesex, Surrey, Devonshire, and Argyleshire.

14.-Angustu, Moore. Linear fronds with a long stipes half the length of the whole frond. Found near Tunbridge Wells, by Miss Bower, and since in Devonshire and Argyleshire.

15.-Alpina, Moore. Narrow ascending pinnx. From Ben Lawers.

16.-Glandulosa, Newman. A glandular form, erect in habit. 17.-Validla, Moore. A stout, leathery, erect, broad frond, from Devonshire and Guernsey.

18. - Schofieldii, Stansfield. Grows from three to four inches high, and is somewhat analogous to the variety Crispum, of Asplenium filix-famina.

For further particulars of these varieties, the reader is referred to the excellent account in Lindley and Moore's Nature-prirted Ferns."

My thanks are due to Mr. Wollaston, of Chisselhurst, for a plant of the variety Collina.

The species is common enough to be procured anywhere. The varieties Nana, Collina, Dumetorum, and Schofieldii, can be procured of Mr. Sim, of Foot's Cray.

The illustration is from a plant in my own collection.

VOI. VI. 




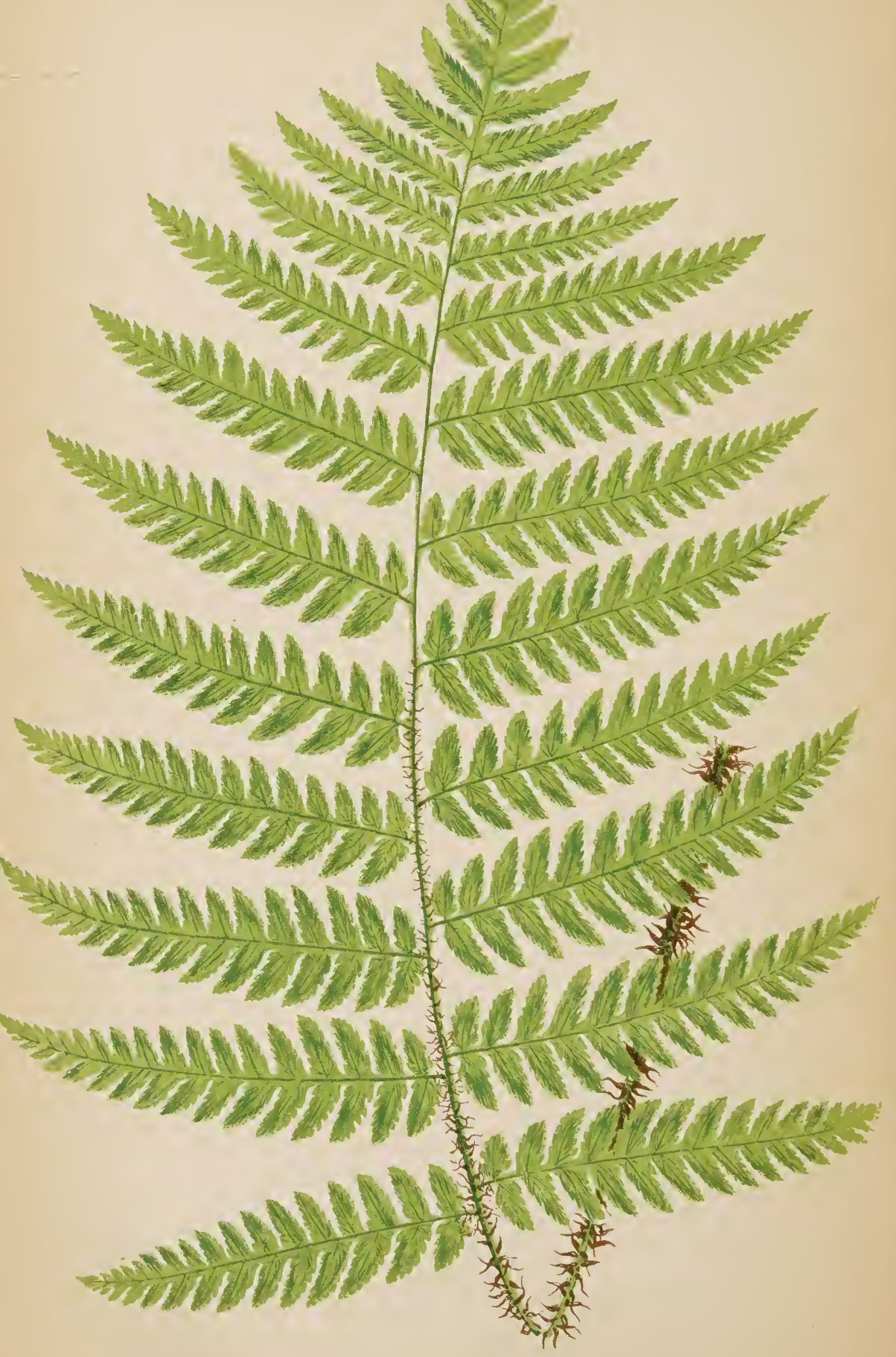

ASEIDIUM GOLDIANUM. 




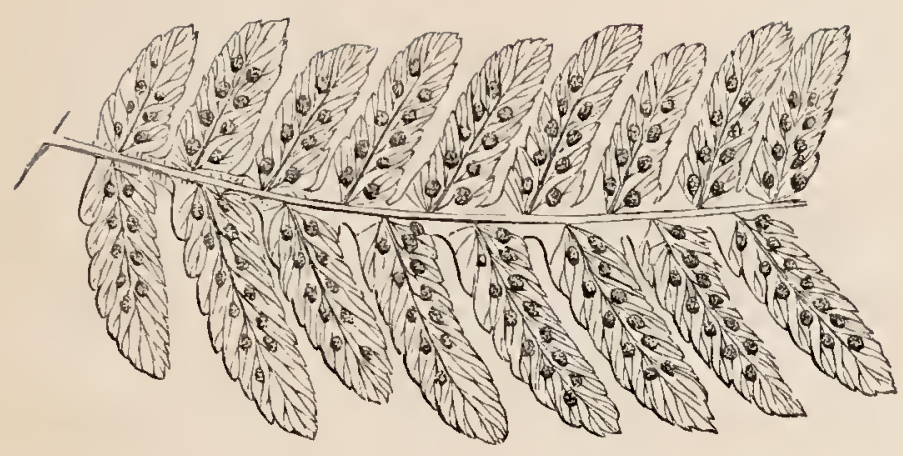

Portion of Pinna of mature Frond-under side.

\title{
ASPIDIUM GOLDIANUM.
}

\author{
Fee. Link.
}

PLATE XXVIII. VOL. VI.

\section{Aspidium Goldieanum, \\ Lastrea Goldiana,
" " \\ Nephrodium Goldianum,}

\section{Aspidium-The Shield Fern. Goldianum-Goldin's.}

Hooker. Kunze.

Presl. J. Sигтн.

Moore and Houlston.

Hooker aND Greville.

In the Section Lastrea of Authors.

A Fine Fern, deserving more general cultivation. Aspidium Goldianum is a native of North America. A hardy deciduous species.

The fronds are broadly lanceolate in form, sub-bipinnate; the pinnæ being broadly lanceolate. Pinnules linear-oblong, somewhat blunt at the apex. Those near the base distant, the upper ones confluent. Margin crenate. 
Stipes and rachis scaly. Fronds terminal, adherent round the crown of a tufted rhizoma.

Sori medial.

Length of frond from twelve to thirty inches; colour pale yellowish green.

For plants I am indebted to Mr. Henderson, of Wentworth; and to Mr. Sim, of Foot's Cray.

It is in the Catalogues of Messrs. Sim, of Foot's Cray; Rollisson, of Tooting; Kennedy, of Covent Garden; Young, of Taunton; and A. Henderson, of Pine-apple Place.

The illustration is from a plant in my own collection. 


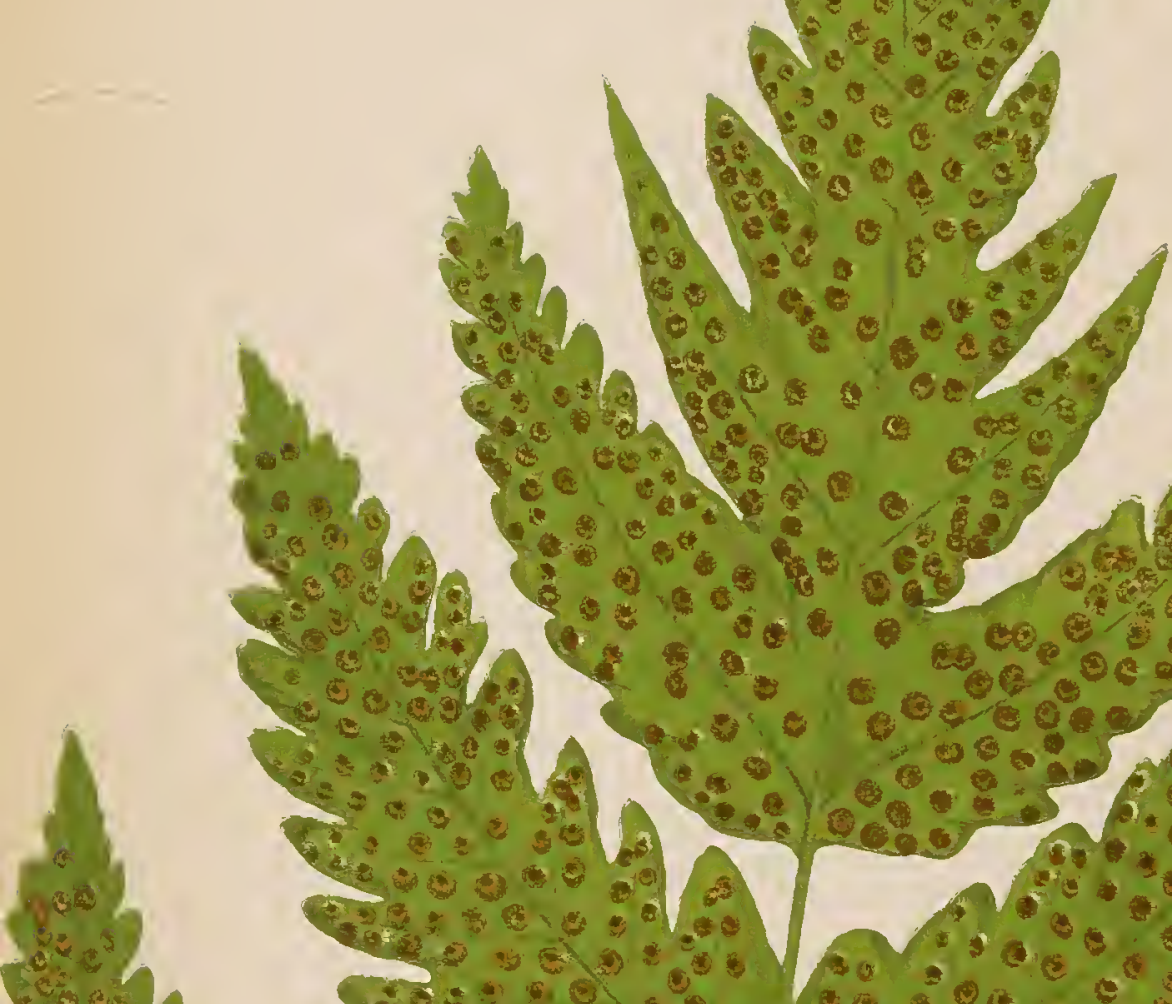

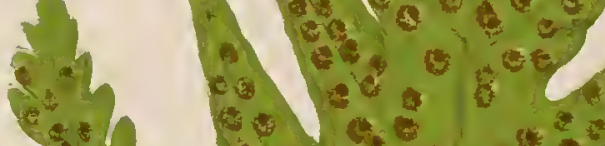

(1.) कै es

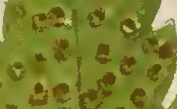

$\sec =\cos$

$(a+0)+2$

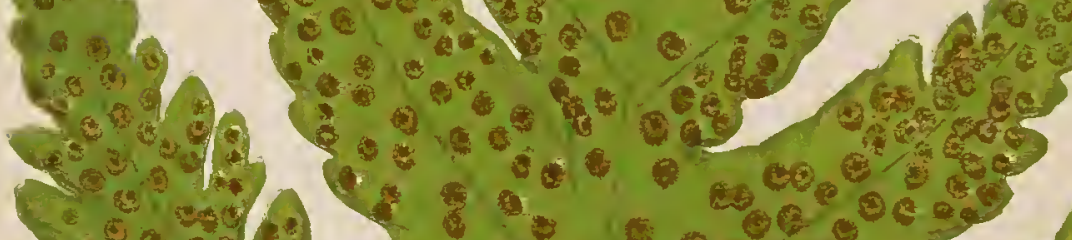

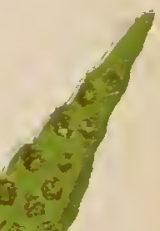

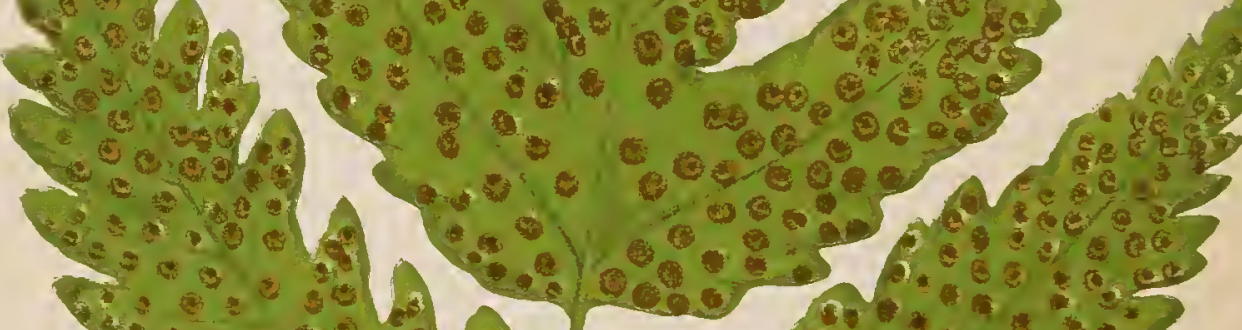

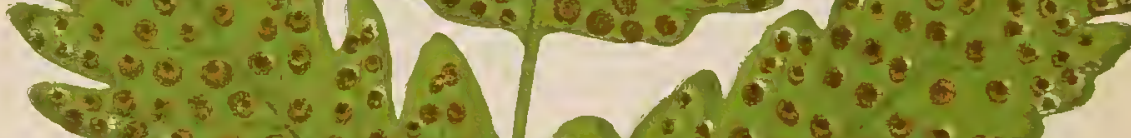

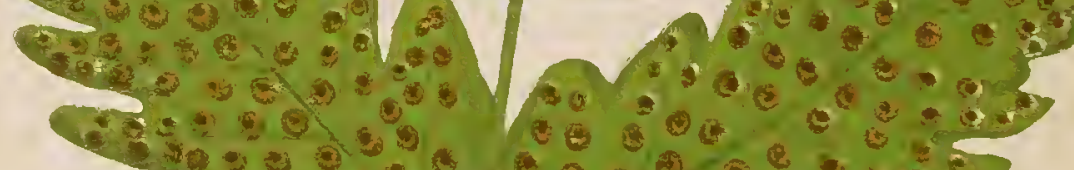

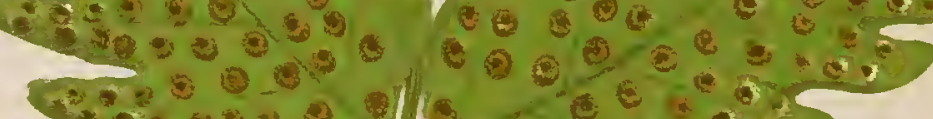

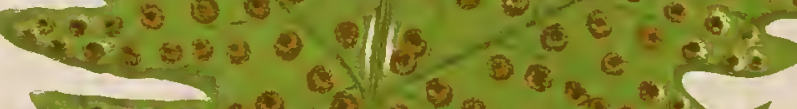





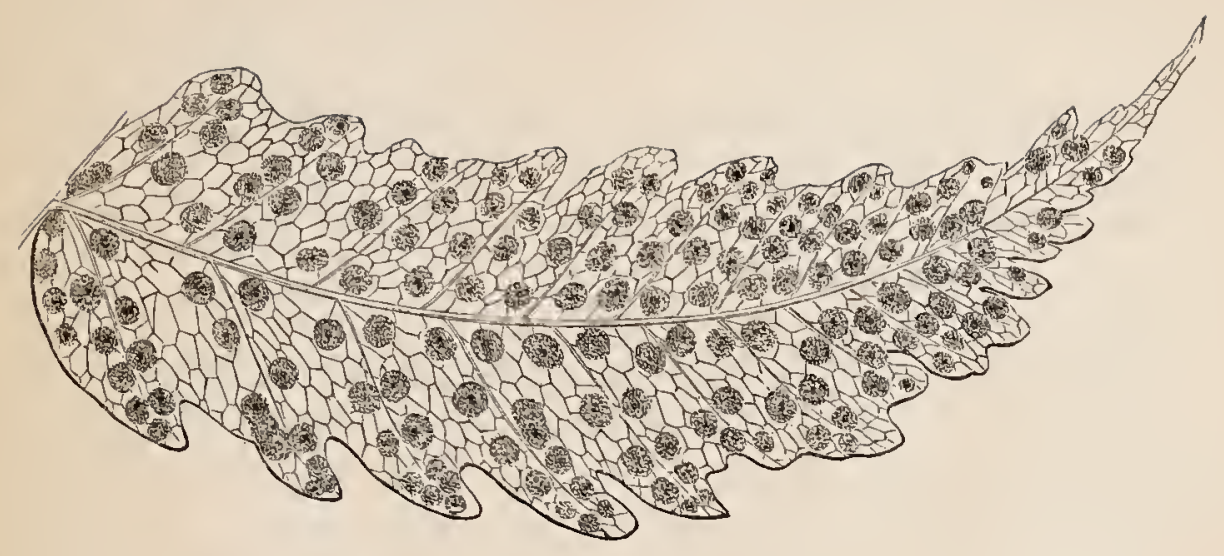

Pinna of mature Frond-under side.

\section{ASPIDIUM TRIFOLIATUM.}

Swartz. Schkuhr. Hooker. Schott. J. Smith. Kunze. Willdenow. Plumier. Moore and Houlston.

PLATE XXIX. VOL. Vr.

\begin{abstract}
Polypodium trifoliatum, Bathium “ Aspidium heracleifolium, Polypodium Pica, Aspidium
\end{abstract}

LinNeUS. JACQUIN.

FEE. LIN K.

Willdenow. Plumier. Porret.

Desvaux.

Aspidium-The Shield Fern. Trifoliatum-Three-leaved.

When well grown this Fern is a magnificent speeies, its bold-looking fronds and gigantie fructification must always place it amongst the most conspieuous of our favourite Ferns.

A stove evergreen species.

Native of the West Indies and Tropical America, Jamaica, and St. Domingo.

Introdueed into the Royal Gardens, Kew, in the year 1769. Fronds glabrous, pinnate, somewhat ereet in habit. The 
inferior pinnæ petiolate, in form nearly triangular trilobate; base cordate; lobes acuminate; centre one largest. Margin bluntly crenate. Superior pinnæ oblong-acuminate, petiolate, base cordate-auriculate; terminal one triangular, sinuately-pinnatifid; segments acuminate; lower ones longest.

Fronds fertile throughout. Stipes dark brown in colour, having a few scattered scales near the base.

Sori circular. Indusium peltate.

Length from twelve to eighteen inches; colour pale green.

My thanks are due to Mr. Stratton, Curator of the Cambridge Botanic Gardens; and to Mr. Clarke, Curator of the Royal Gardens, Glasgow; for plants of this species.

It may be procured from the following Nurserymen:-Booth and Sons, of Hamburg; Sim, of Foot's Cray; Veitch, Jun., of Chelsea; Rollisson, of 'Tooting; Kennedy, of Covent Garden; Stansfield, of 'Todmorden; E. G. Henderson, of St. John's Wood; and A. Henderson, of Pine-apple Place.

The illustration is from a plant in my own collection. 




$$
\text { • }
$$



Timna of mature Frond-under side.

\section{ASPIDIUM MOLLE.}

Swartz. Kunze. Link. Wilidenow. Schkuhr.

Raddi. Sfrengel.

PI.ATE XXX. vOI. VI.

Aspidium violascens,

Nephrodium molle,

" "

640

"pubesccns,

Polypodium

" nymphale,

Aspidium-The Shield Fern.
LINK.

R. Brown. Schotт. J. Sмith.

Fee. Moore and Houlston.

Presl.

Dos.

JACQUTN.

Schkuirr. Forstels.

Molle-Soft.

In the Section Nephrodium of Authors.

Although a very common, still a very desirable free-growing species, and well adapted for cultivation as a specimen. In a greenhousc or stove there can scarcely be a greatcr weed than Nephrodium molle, as it is so readily propagated from spores. Introduced into England in the year 1820.

A stove or warm greenhouse species, from Tropical America, Brazil, Rio de Janerio, Mauritius, and Mexico.

Fronds lanceolate and pubescent; the pinnæe being linear- 
oblong, acuminate, pinnatifid, and petiolulate. The segments linear-oblong obtuse, being largest next the rachis. Terminal, adherent to a thick somewhat creeping rhizoma.

Stipes slightly scaly near the base.

Indusium very hairy, and pale violet in colour.

Length of frond from twelve to thirty inches.

For plants my thanks are due to Sir Oswald Mosley, Bart., of Rolleston Hall; Mr. F. Wright, of Osmaston Manor; Mr. Stewart, gardener to Lord Vernon; Mr. Ingram, gardener to the Duke of Rutland; and to Mr. Cooling, of Derby.

It is in the Catalogues of Messrs. A. Henderson, of Pineapple Place; Stansfield and Son, of Todmorden; Kennedy, of Covent Garden; Bass and Brown, of Sudbury; Masters, of Canterbury; Rollisson, of Tooting; Cooling, of Derby; Sim, of Foot's Cray; and Veitch, of Chelsea. 


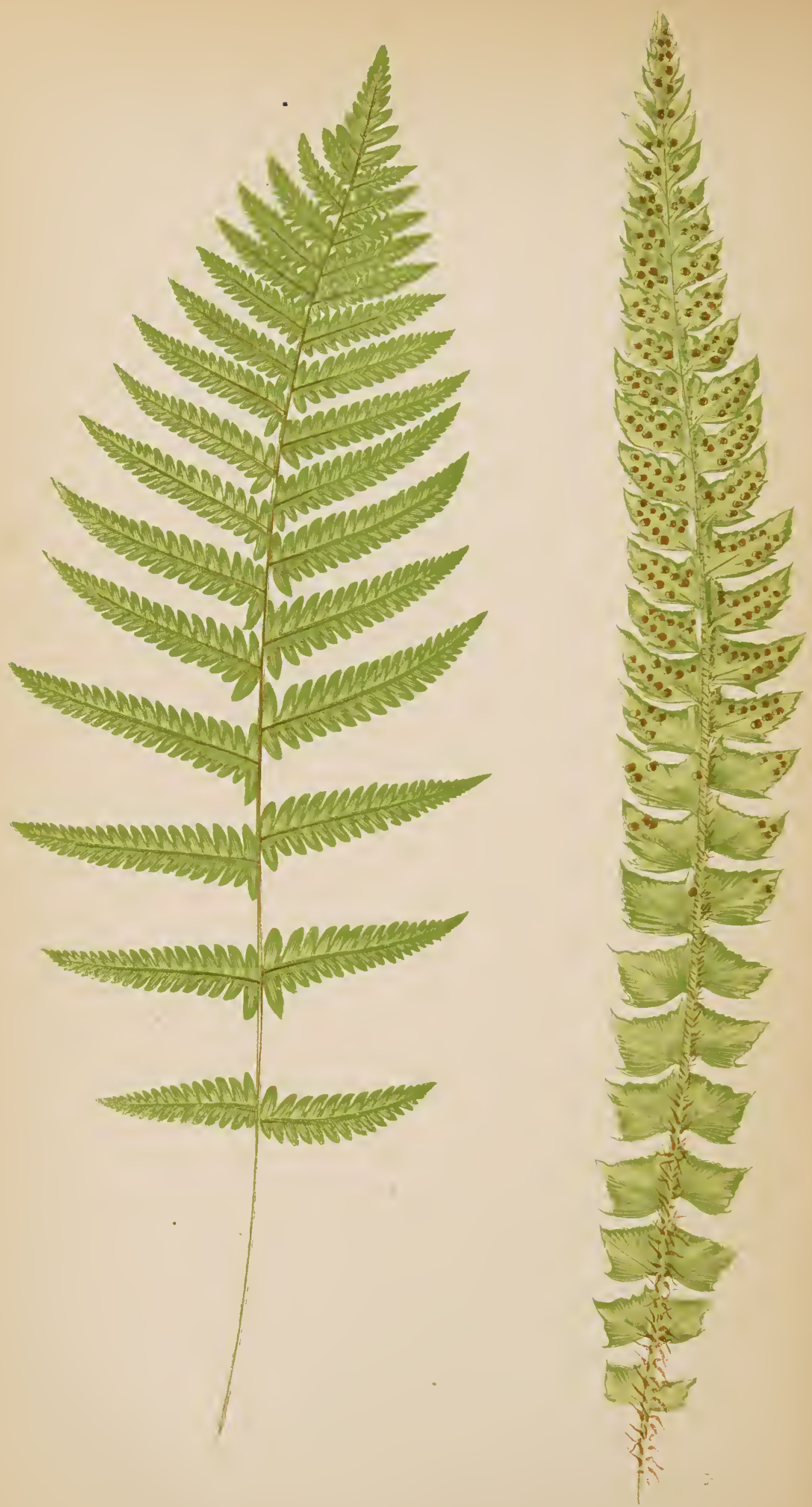




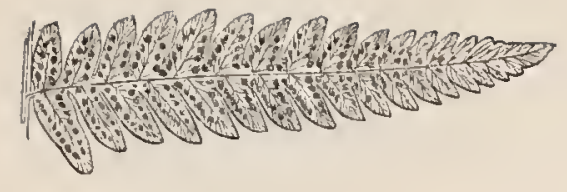

Pinna of mature Frond, under side.

\section{ASPIDIUM THELYPTEROIDES.}

Swartz.

PLATE XXXI.-A. VOL. VI.

Aspidium noveboracense,

"،

،

" pumilum,

Nephrodium thelypteroides,

Polypodium noveboracense,

Aspidium-The Shield Fern.
Link. SWartz. Willdenow. SchKurr. Kunze.

OF Gardens.

Micitatx.

LINNEUS.

TheTypteroides?

In the Section Lastrea of Autiors.

TuE present speeies, although more dwarf in habit than Aspidium thelypteris, still in all its eharaeters it so nearly approaehes $A$. thelypteris of $\mathrm{Swartz}$, and $A$. pumilum of gardens, that $I$ have hesitated in plaeing it as distinet from that speeies; the illustration, however, is given as a guide to the eultivator.

A North Ameriean Fern, and in all probability only a variety of our British A. thelypteris.

For a plant I am indebted to Mr. Sim, of Foot's Cray.

There appear to be two forms in North America, the one known as Lastrea noveboracense, and the other as L.thelypteroides; the former differs in a slight degree in having its ereeping VOL. VI. 
rhizoma "crceping above the ground," and in being more compact in its growth.

Both forms are in the Catalogues of Mr. R. Sim, of Foot's Cray; Rollisson, of Tooting; Kennedy, of Covent Garden; and Booth and Son, of Hamburg.

'The illustration is from a plant in my own collection. 


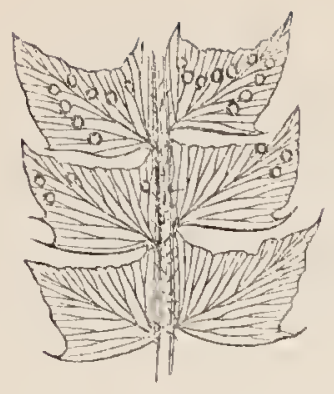

Portion of mature Frond, under side.

\section{ASPIDIUM MUCRONATUM.}

Swartz. Schiehr. Kunze. Sprengel. Sloan.

PLATE XXXI.-B. YOL. VI.

$\begin{array}{cl}\text { Polystichum } \\ \text { mucronatum, } & \text { Prest. J. Smitif. Fet. } \\ \text { Nephrodium Sloanci, } & \text { Moore and Hodiston. }\end{array}$

Aspidium-The Shield Fern. Mucronatum-Sharp-pointed.

In the Section Pofystichum of Authors.

A LOVELy dwarf, close-growing, evergreen, scarce species; seldom to be met with in private collections. Easily cultivated.

A stove Fern.

Native of Jamaica.

Introduced into England in the year 1838.

Fronds pinnate, linear-lanceolate in form; pinnx petiolate, oblong-ovate, mucronate; lower ones sub-hastate; superior base auriculate; inferior base obliquely wedge-shaped; margin serrate, with long spiny teeth. 
Rachis and stipes chaffy. Terminal, adherent to a tufted rhizoma.

Sori bold.

length of frond twelve inches; colour decp shining green.

For plants I am indebted to Mr. J. Smith, Curator of the Royal Gardens, Kew; and to Mr. Pass, gardener to Mr. Brocklehurst, of the Fence, near Macclesfield.

It is in the Catalogue of Mr. R. Sim, of Foot's Cray, Kent. The illustration is from a plant in my own collection. 



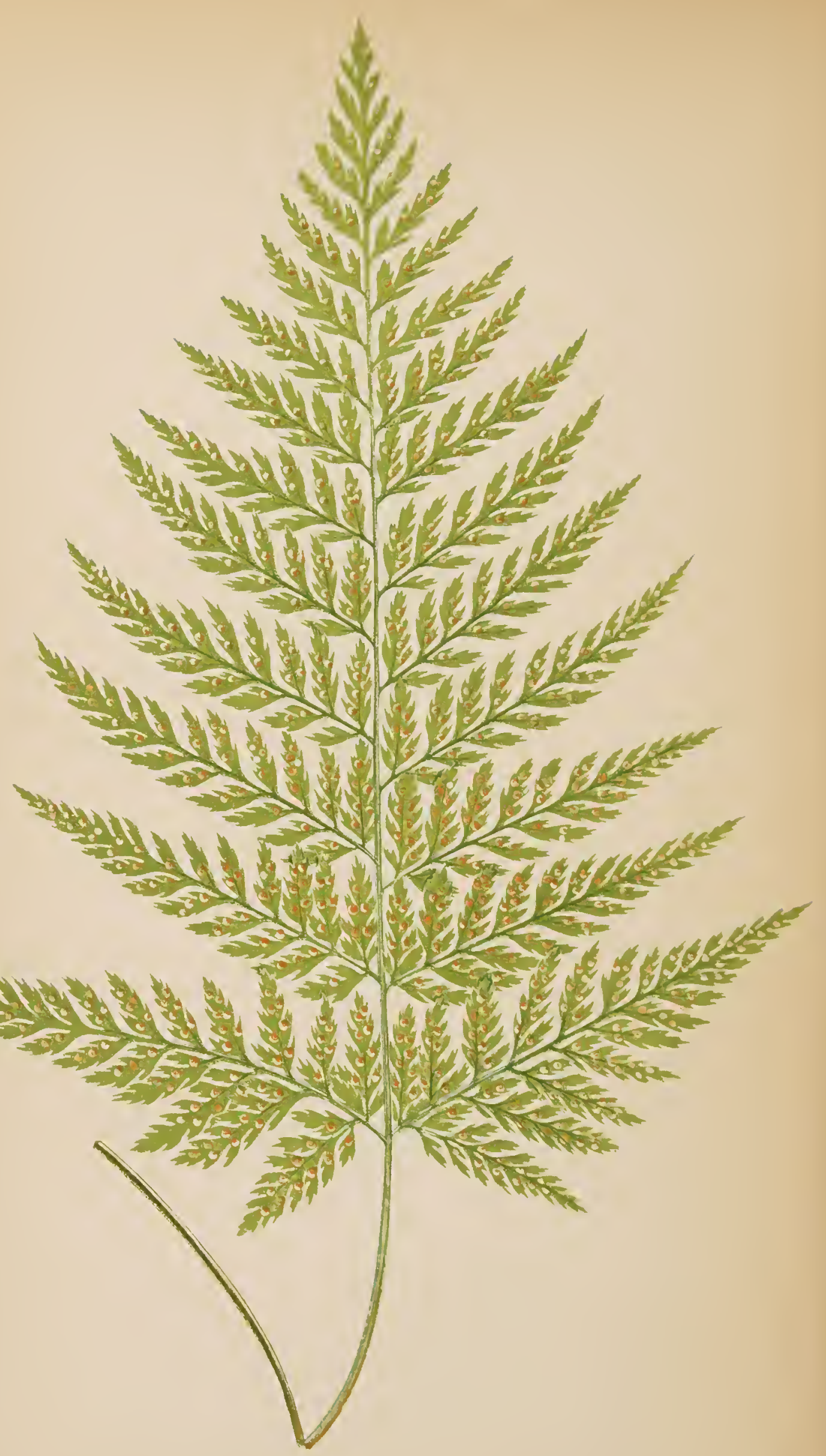




$$
\text { . }
$$





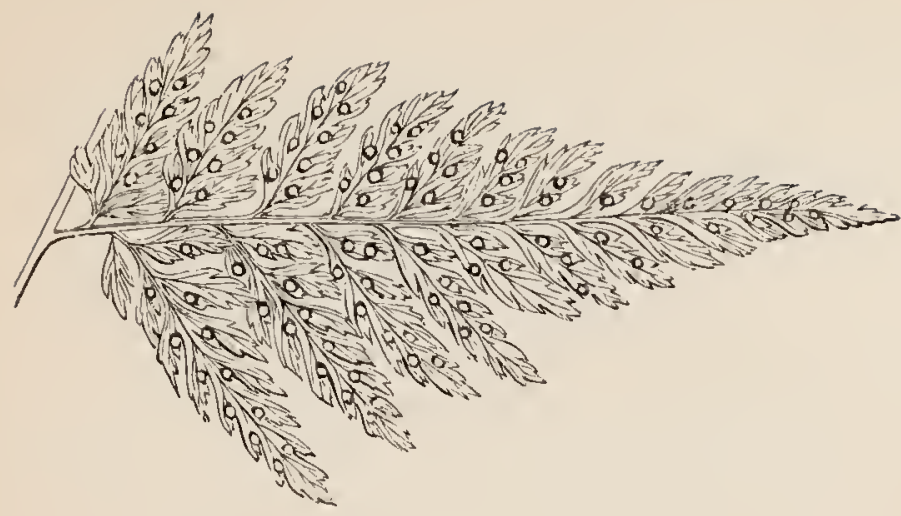

Pinna of mature Frond, under side.

\section{ASPIDIUM GLABELLUM.}

PLATE XXXII, VOL, VI.
Lastrea glabella,
J. Smith. Moore and Houlgton.
Nephrodium glabellum,
A. Cunningham.

Asplenium-The Shield Fern.

Glabellum-Smoothish.

In the Section Lastrea of Authors.

As interesting, pretty, dwarf, delicate Fern; rather rare in cultivation.

An cvergreen warm greenhouse species.

Native of New Zealand.

The fronds are glabrous, triangularly-elongate in shape, subtripinnate; the pinnæ being triangularly-elongate; the pinnules oblong-linear, pinnatifid; the basal pinnules entire; upper ones confluent, having toothed segments.

Stipes having a few scales near the base. Terminal, adherent to a tufted rhizoma.

Sori medial.

Length of frond twelve inches; colour pale green. VOL. VI. 
For a plant of this species I am indebted to Mr. R. Sim, of Foot's Cray.

It nay be procured of Messre. Rollisson, of Tooting, and Sim, of Foot's Cray.

The illustration is from a plant in own collection. 

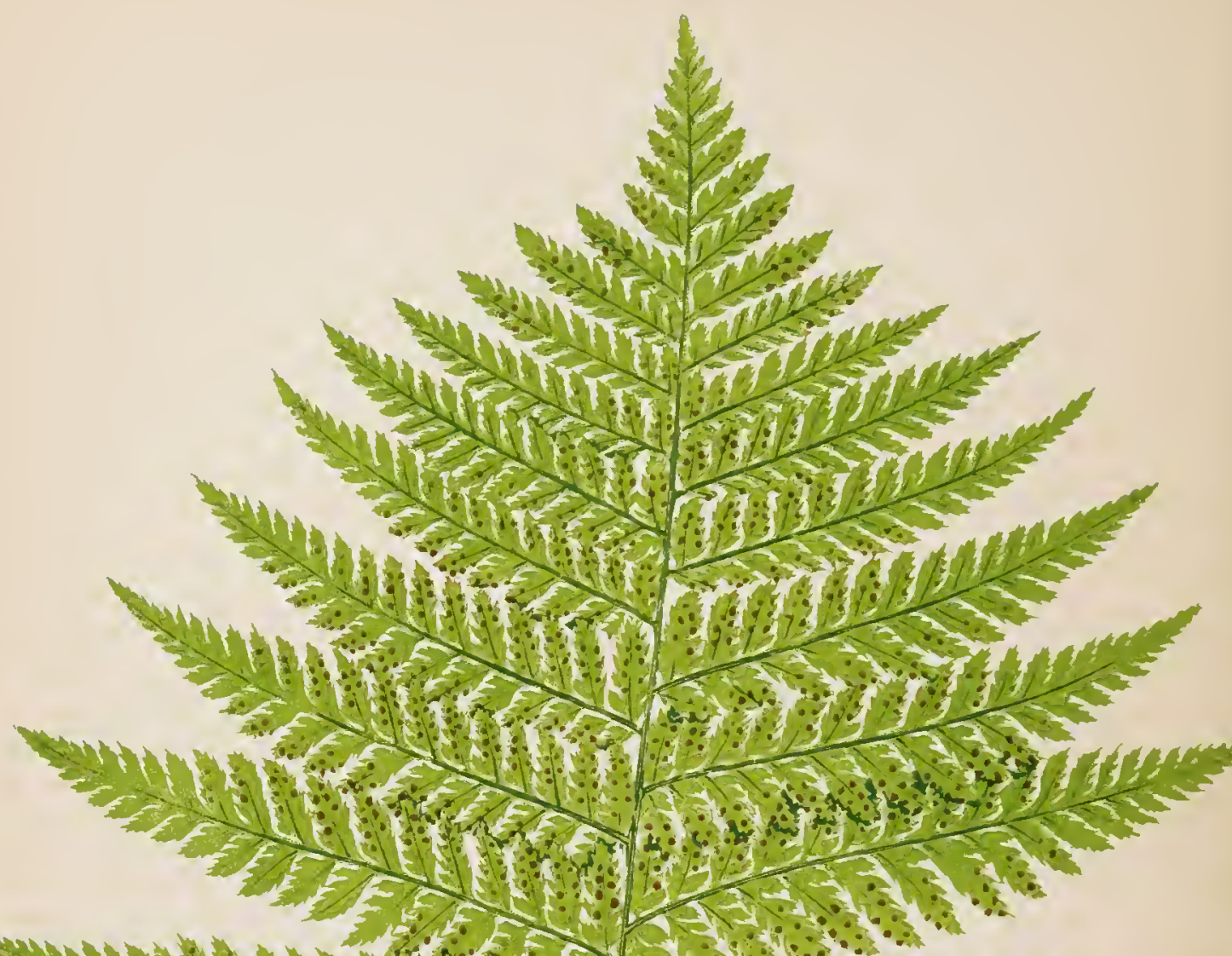

mand

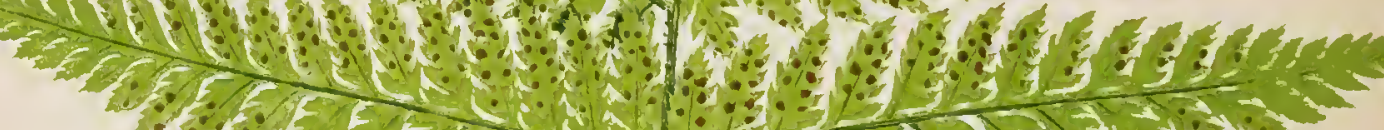

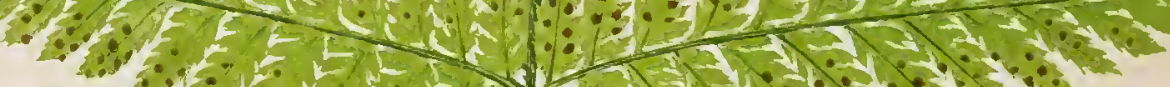

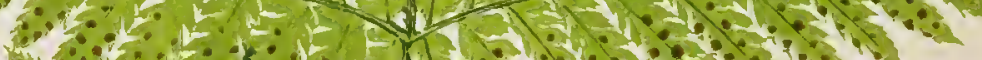

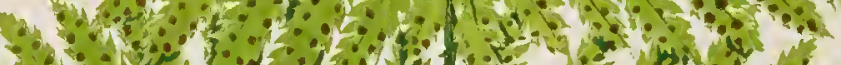



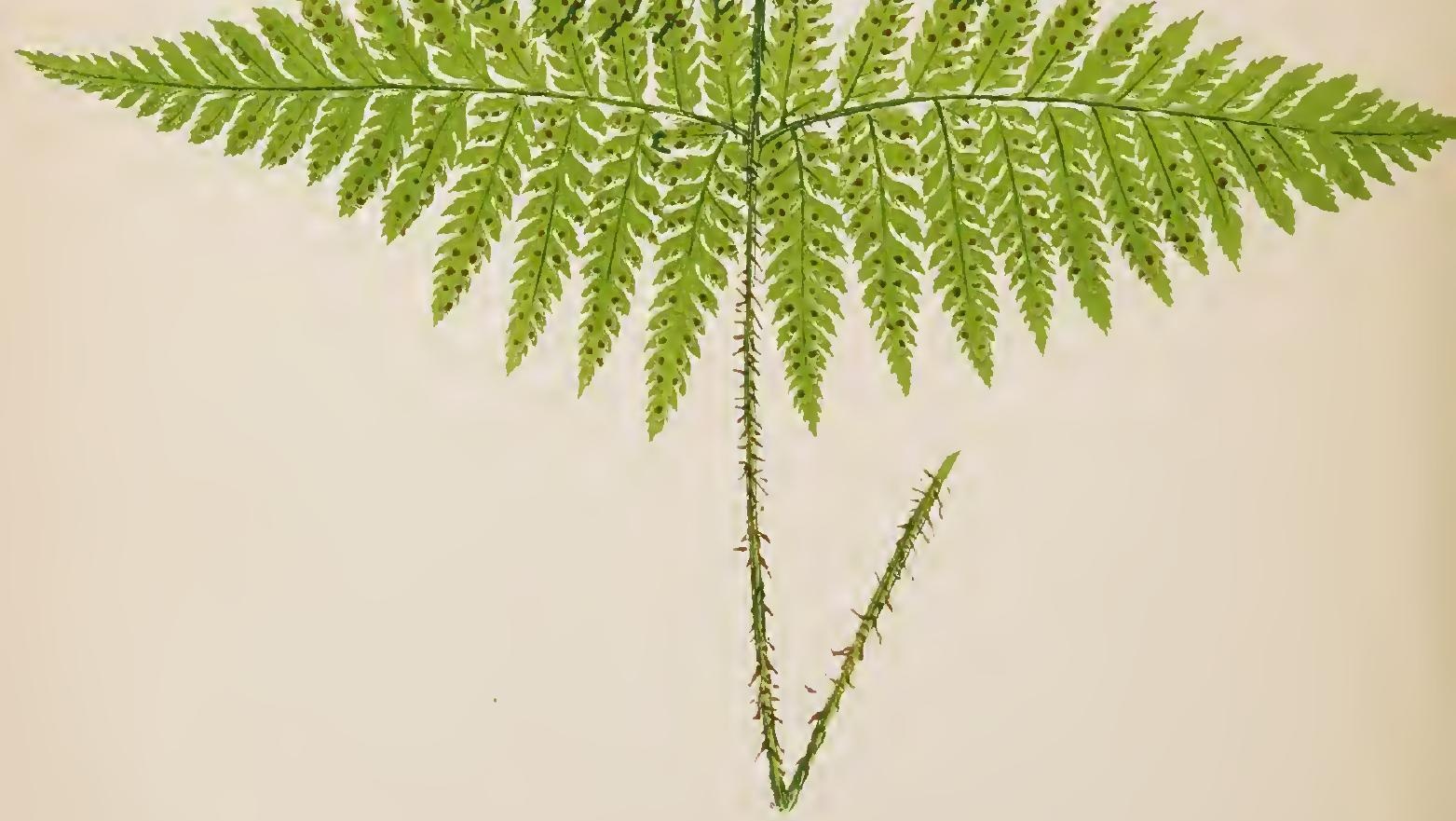






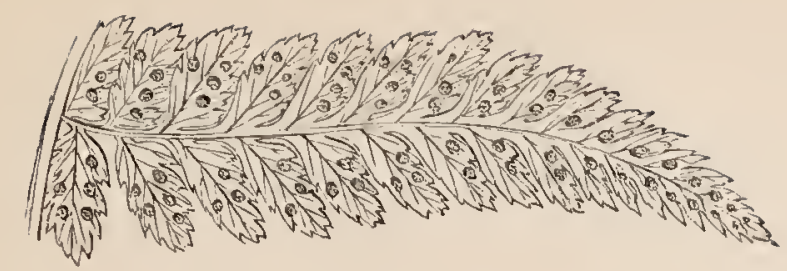

Pinna of mature Frond, under side.

\title{
ASPIDIUM DECOMPOSITUM.
}

\author{
Kunze. Fee.
}

PLATE XXXIII, VOL. VI.

Lastrea decomposita,

Nephrodium decompositum,

Aspidium-The Shield Fern.
J. Smith, Moore \& Houlston.

R. BRown.

Decompositum-Decomposed.

In the Section Lastrea of Authors.

A somewhat similar-looking species to the Aspidium pubescens of Swartz, without the pubescence which is so conspicuous in that species.

An evergreen warm greenhouse Fern.

Native of New Holland.

Fronds cuneate in form, in somc degree membranous, deltoid, and tripinnate; pinnules oblong, inciso-pinnatifid, with dentatc segments.

Rachis and midrib of pinnæ pubescent.

Stipes scattered over with small dark brown scales.

Fronds lateral, adherent to a crceping rhizoma.

Length of frond from eighteen to twenty-four inches; colour light green.

Sori medial.

VOL, VI. 
Introduced into the Royal Gardens, Kew, by Mr. A. Cunningham, in the year 1825 .

For plants of this species I am indebted to Mr. R. Sim, of Foot's Cray, and to Messrs. Booth, of Hamburg; and for fronds to Mr. J. Henderson, of Wentworth.

It is in the Catalogues of Messrs. Sim, of Foot's Cray; E. G. Henderson, of St. John's Wood; Veitch, of Chelsea; A. Henderson, of Pine-apple Place; Kennedy, of Covent Garden; Cooling, of Derby; Booth, of Hamburg; and Stansfield, of Todmorden.

The illustration is from a plant in my own collection. 


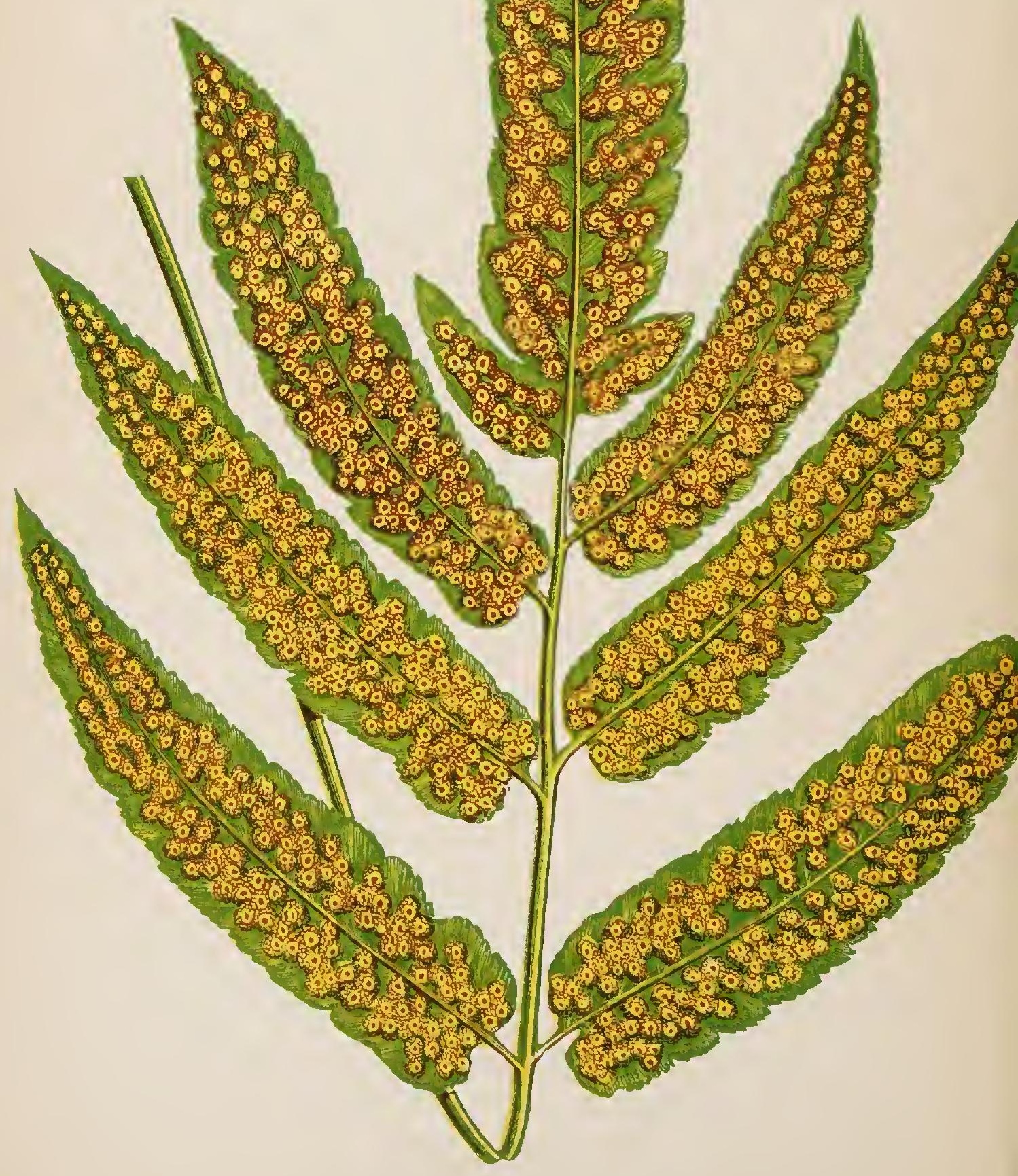





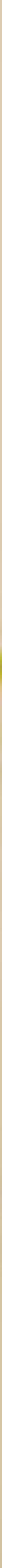

ASEIDIUM PODOPHYLLUM-BARREN FHONJ $X X X V-V O L .6$. 



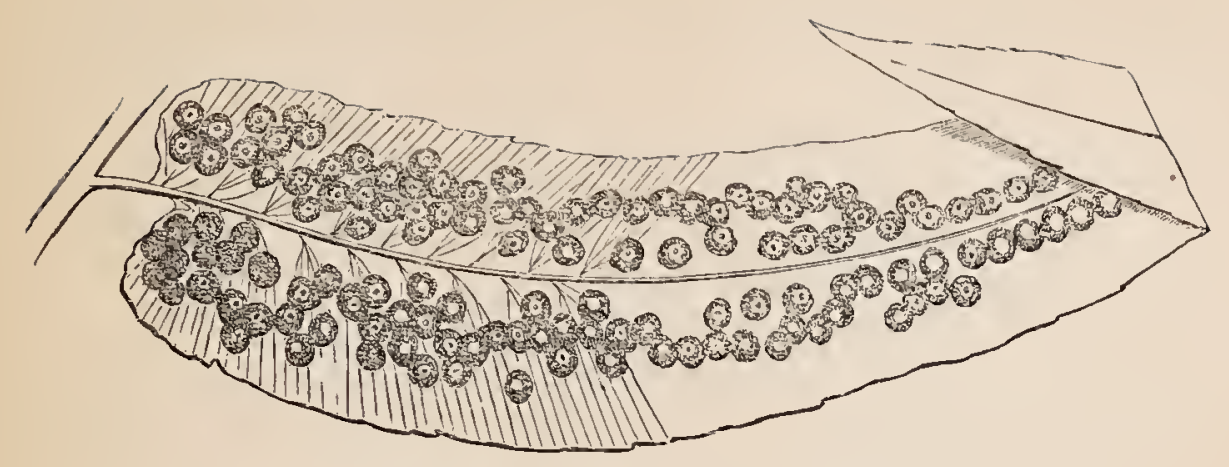

Pinna of mature fertile Frond, under side.

\section{ASPIDIUM PODOPHYLLUM.}

\section{HOOKER.}

PIATES XXXIV AND XXXY. VOL. VI.

\author{
Aspidium Sieboldi, \\ Lastrea podophylla, \\ Pycnopteris Sicbuldi, \\ Lastrea Sieboldi,
}

Van Houtte. Metten.

J. SMith.

Moore.

Moore.

Aspidium-The Shield Fern.

Podophyllum-Foot-stalk leaved.

(From the circumstance that the basal pinno have foot-stalks.)

In the Section Lastrea of Authors.

A VERY handsome and distinct Fern, having fertile fronds different to the barren fronds.

An evergreen greenhouse species, at least usually considered as such, but said to be hardy enough in our English climate, having survived the winter of 1854-5 in the open air.

Native of Japan, and China, (in the neighbourhood of HongKong.)

The fronds, which are leathery in consistency, are pinnate, 
broad, smooth, and having very few thick pinnæ, usually seven, obliquely oblong-lanceolate, falcate, and being serrulate irregularly; the lowest stalked, and unequally cordate at the base; the upper pinnæe sessile and decurrent.

The pinne of the barren fronds are somewhat undulated. The stipes exceedingly stout at the base, where it is covered with long, narrow, pointed scales.

In the fertile fronds, which are entirely covered with sori, the stipes is longer, and the pinnæ are more contracted.

Sori very large and numerous, being a large mass of elevated spore-cases irregularly bi-tri-serial, at first pale green, and afterwards black.

Veins having club-shaped apices.

Rhizoma erect.

Introduccd into Great Britain by M. Van Houtte, of Ghent, in 1852.

This species was discovered in China, by Dr. Von Siebold.

Stipes scaly below, ebeneous, except along the under edge, wherc green.

Fronds adhcrent to a broad rhizoma.

Length of frond from twelve to fifteen inches, the leafy portion being as broad as it is long. Breadth of barren pinna one inch and three quarters; of fertile pinnæe an inch. Length of stipes of barren frond from three to four inches, and of fertilc frond five inches.

Colour of frond a dull green, paler beneath.

Aspidium podophyllum has the venation of a Polystichum, and the fructification of a Lastrea.

My thanks are due to Mr. Joseph Henderson, of Wentworth; and to Mr. Stansfield, of Todmorden, for plants of this species; and to Mcssrs. Veitch, Jun., of Chelsea; Mr. J. Henderson, of Wentworth; Mr. G. Norman, of Hull; Mr. J. W. Jeans, of Grantham; and to M. Schott, Director of the Imperial Gardens of Vienna, for fronds.

It is in the Catalogues of Messrs. Veitch, of Chelsea; E. G. Ilenderson, of St. John's Wood; A. Henderson, of Pine-apple Place; Sim, of Foot's Cray; Rollisson, of 'Tooting; Masters, of Canterbury; Booth, of Hamburg; Cooling, of Derby; Young, of Taunton; and Stansfield, of Todmorden.

The illustrations are from a plant in my own collection. 
. 


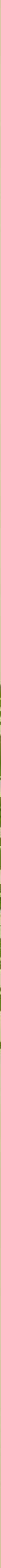






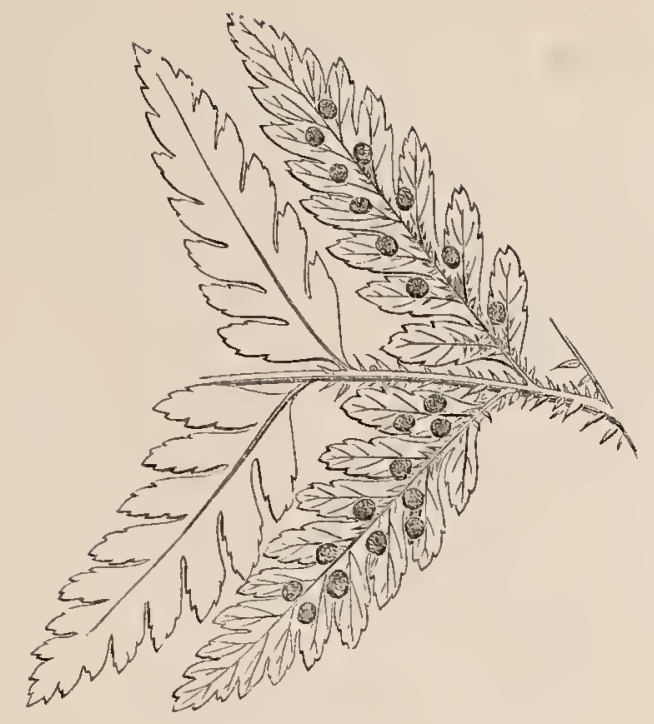

Portion of pinna of mature Frond, under side.

\section{ASPIDIUM CORIACEUM.}

\section{LOWE.}

PLATE XXXVI. VOL. VI.
Polystichum coriaceum,
J. SMITH.
"flexum,
Of Sim's Catalogue.

Aspidium-The Shield Fern.

Coriaceum-Leathery.

In the Section Polystichum of Authors.

A noble evergreen species, only to be found in the larger collections.

A very dissimilar Fern has been for some years under cultivation, bearing the above name, and which is the Aspidium coriaceum of Swartz. 
A warm greenhouse or stove Fern.

Native of the south of Africa-Cape of Good Hope.

Fronds triangular in form, spreading, erect in habit, stout, dull green, tripinnate; pinnules pinnatifid and slightly recurved.

Stipes and rachis everywhere hirsute, with broad dark scales scattered here and there, darker and larger near the base. Stipes very stout.

Rhizoma densely scaly, and creeping.

Sori copious, occupying the whole frond, smaller than in A. capense.

Length of frond thirty-six inches; width at base about twenty inches. Stipes sixteen inches in length.

For a plant and fronds of this Fern I am indebted to Mr. R. Sim, of Foot's Cray.

It may be procured of Mr. R. Sim.

The illustration is from a plant in my own collection. 



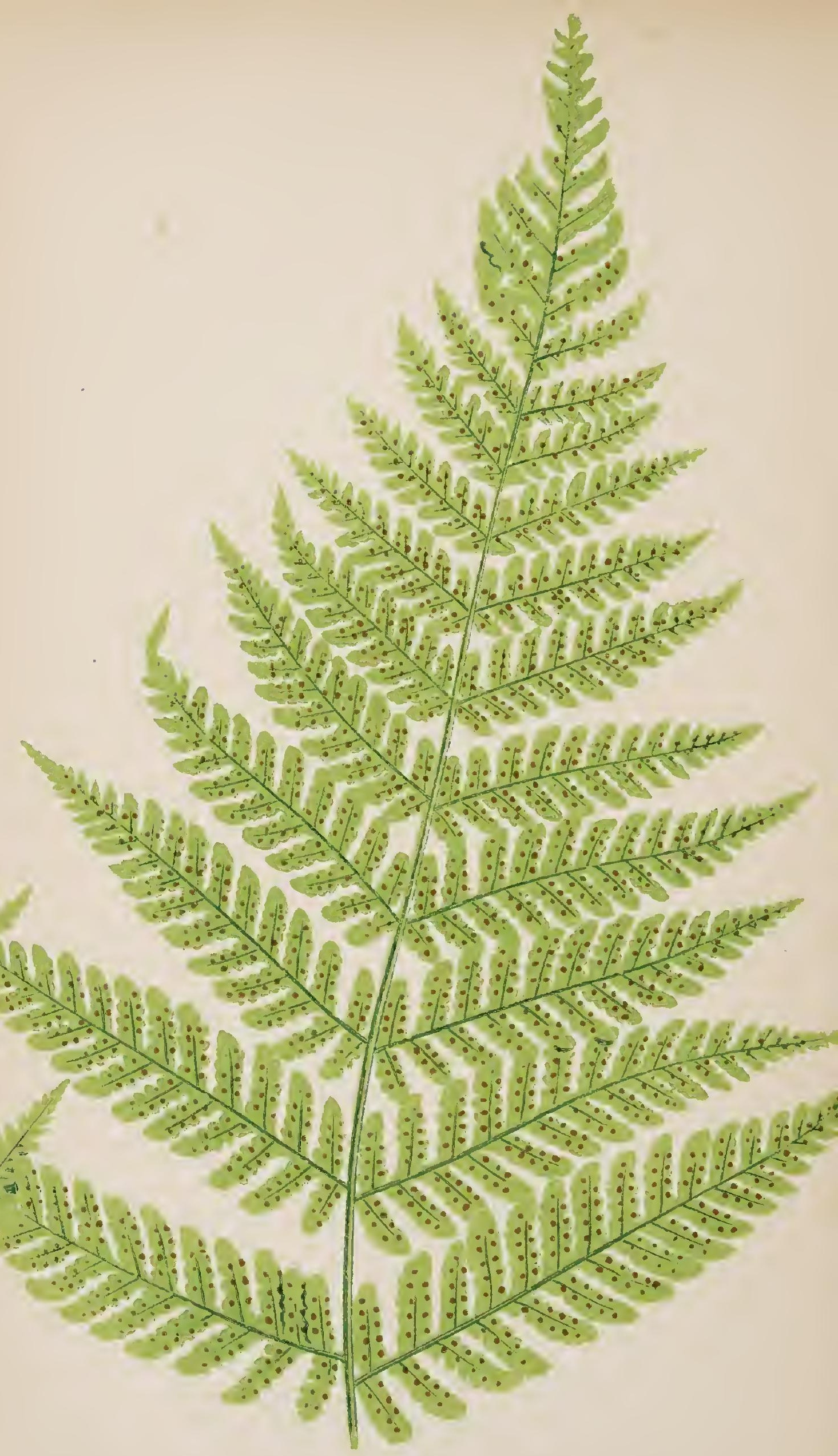

SPIIUM VILLOELM-LOKIION OF FRONI. 




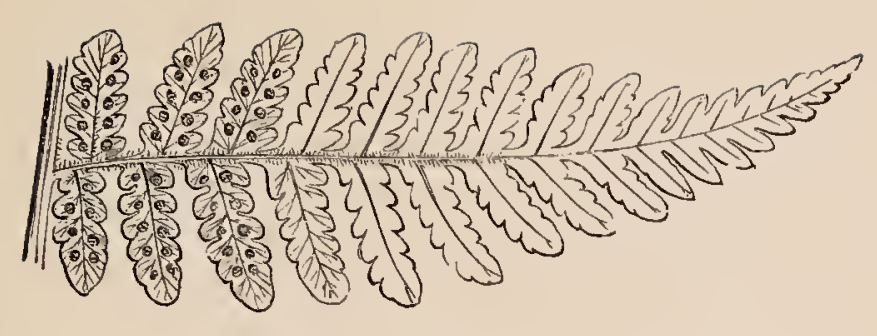

Pinna of mature Frond, under side.

\section{ASPIDIUM VILLOSUM.}

Swartz. Schkuhr. Kunze. Fee. Petiver. Slohn.

PLATE XXXVII. VOL. VI.

\section{Tastrea villosa, " " \\ Polypodium villosum,}

Aspidium-The Shield Fern.

\author{
Presl. J. Smith. \\ Moorte and Houlston. \\ Swartz. Plumier.
}

Villosum-Hairy.

In the Section Lastrea of Authors.

THus giant Fern of the section Lastrea is a noble species when well grown.

An evergreen stove species.

Native of the West Indies, Jamaica, and Caribbee.

Introduced into the Royal Gardens, Kew, in 1844 , by $\mathrm{Mr}$. N. Wilson.

Fronds triangularly elongate, tri-quadripinnate; pinnules oblong-linear, rather obtuse, deeply pinnatifid; segments oblong, apex circular.

Fronds very hairy, terminal, adherent to an arboresccnt caudex. Rachis and stipes completely covered with narrow fringed scales. VOL. VI. 
Length of frond from ten to twelve feet; colour pale green. Sori medial.

Indusium glandulose.

For fronds of this Fern I am indebted to Messrs. Veitch, Jun., of the Exotic Nursery, Chelsea.

It may be procured of Messrs. Veitch, of Chelsea; A Henderson, of Pine-apple Place; and Kennedy, of Covent Garden. The illustration is from a frond sent by Messrs. Teitch. 


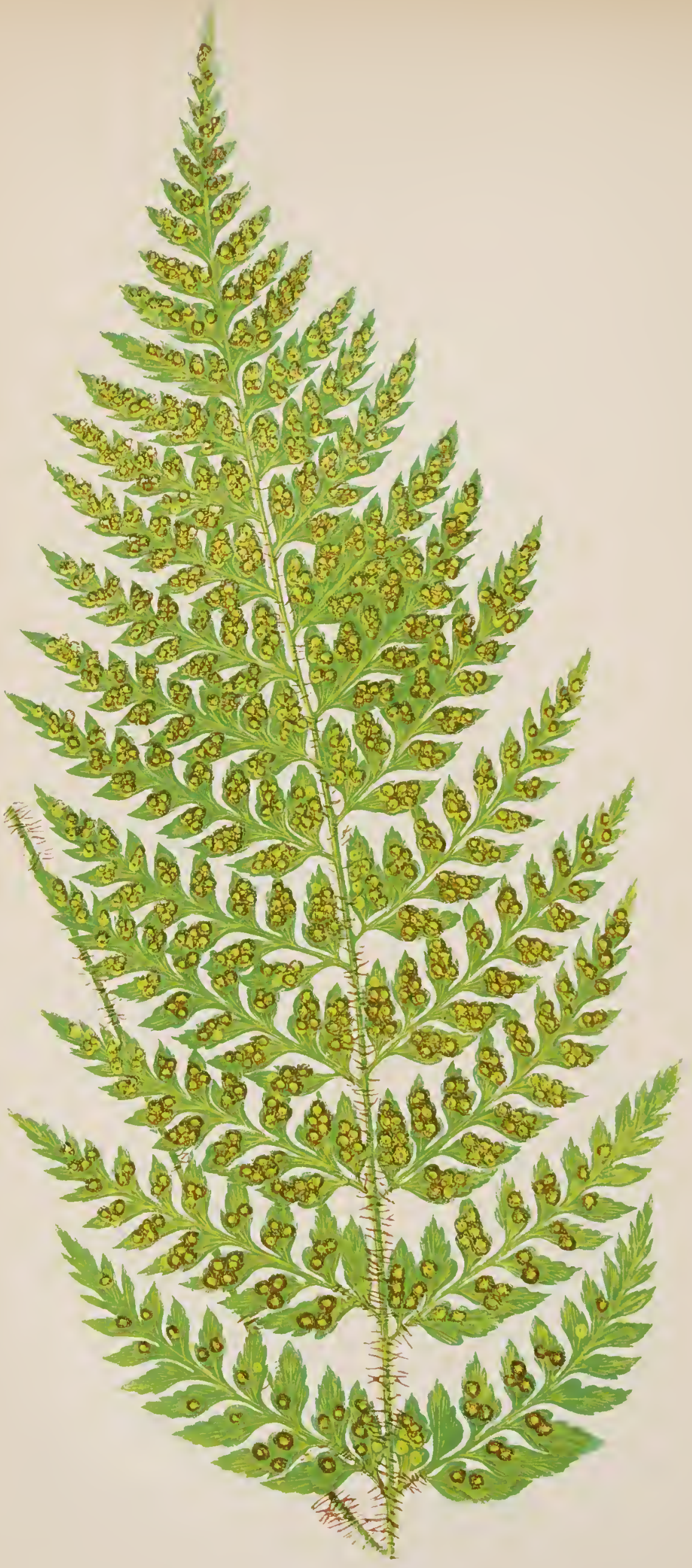





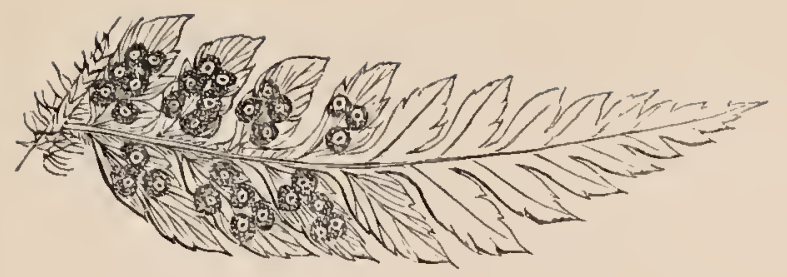

Pinna of mature Frond, under side.

\section{ASPIDIUM VESTITUM.}

Swartz. Schkuhr. Kunze. Kaulfuss, not of Sieber, nor of WILLdenow.

PLATE XXXVII. VOL. VI.

\author{
Polystichum vestitum, \\ 66 of \\ Polypodium vestitum,
}

Aspidium-The Shield Fern.

\author{
Presl. J. Suith. \\ Moore and Houlston. Fee. \\ Forster, not of RADDI.
}

Vestitum-Clothed.

In the Section Polystichum of Authors.

Turs most interesting species is not generally cultivated, except in our best collections. It has a more dwarf growth than most of the species in the section Polystichum, and makes a very pretty specimen plant.

An evergreen greenhouse species.

Native of New Zealand, Tasmania, (Van Diemen's Land,) New Holland, and Chili.

The present species must not be confounded with the Lastrea vestita of J. Smith, nor with the Polystichum proliferum of Presl: it is not unlike the latter, exccpt in bcing more rigid, 
having a much longer stipes, and not being viviparous at the apex.

Fronds rigid, bipinnate, almost lanceolate in form, having oblong-acute pinnx, with rather ovate pinnules, in some degree auriculate; base wedge-shaped, only one or two pairs are distinct, the remainder being confluent, with a sharp mucronate tooth on the apex.

Fronds terminal, adherent to a tufted rhizoma, the lower half of the frond naked.

Rachis and stipes densely clothed with narrow scales.

Length of frond from twelve to eighteen inches; colour rich dark green.

Introduced into the Royal Gardens, Kew, in the year 1842, having been received from Mr. J. Edgerley.

My obligations are due to Mr. J. Henderson, of Wentworth, for fronds of this species.

It is in the Catalogues of Messrs. Sim, of Foot's Cray; and Kennedy, of Covent Garden.

The illustration is from a frond sent by Mr. Joseph Henderson. 


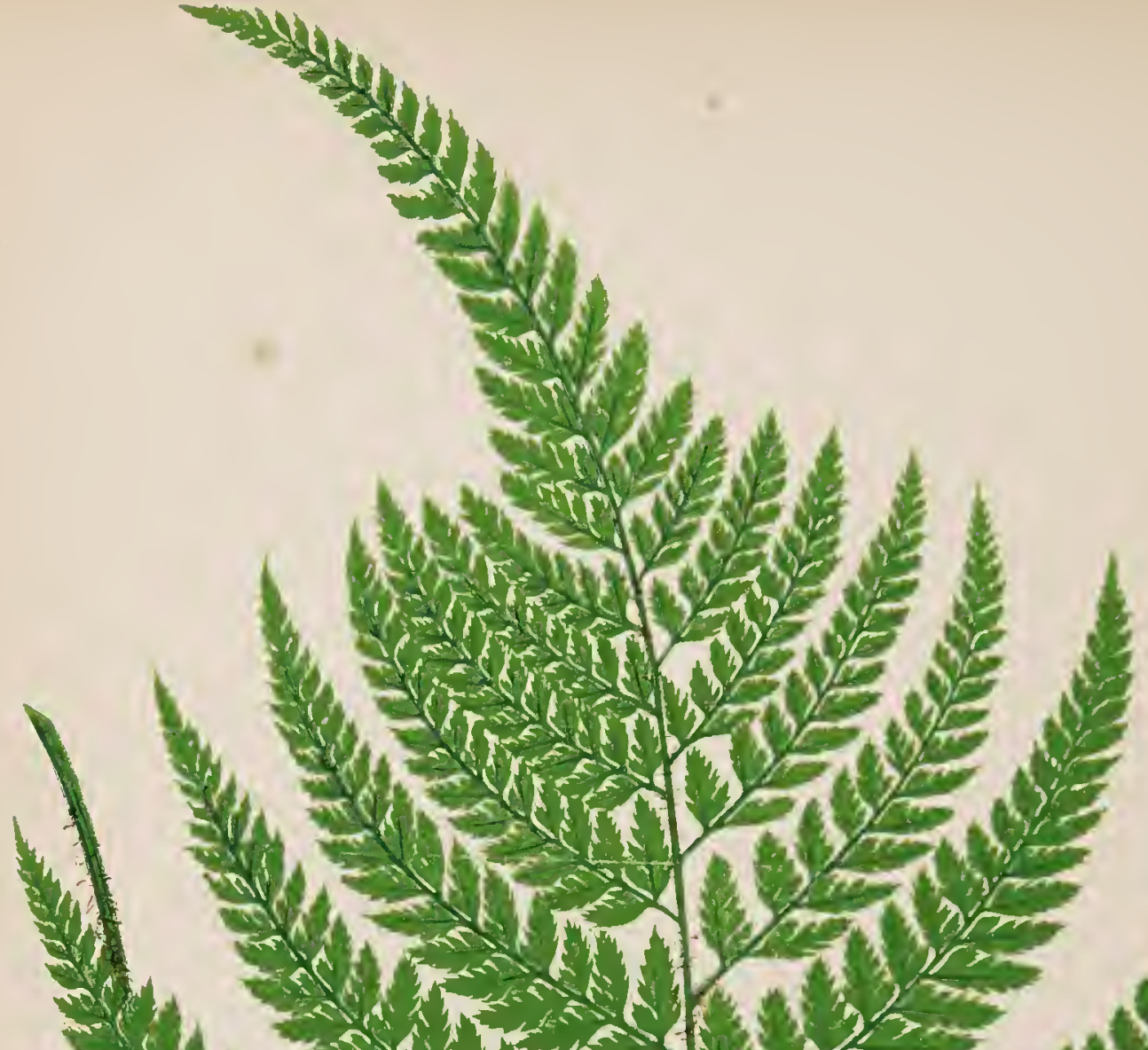

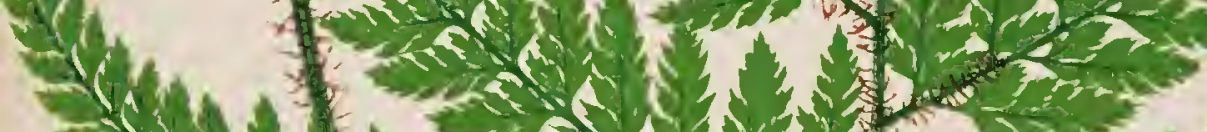

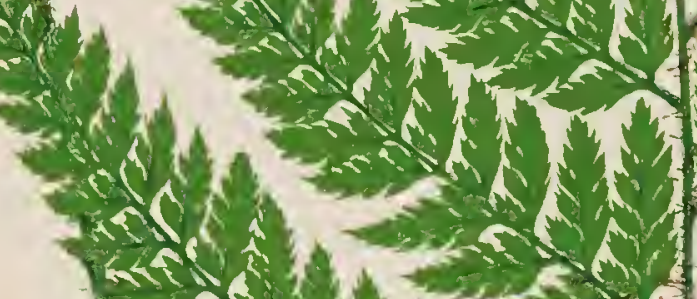


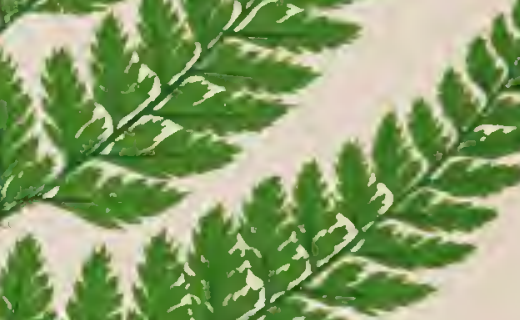




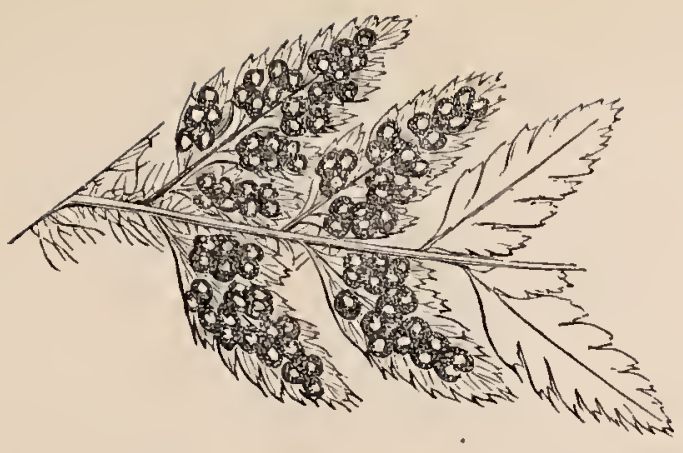

Portion of pinna of mature Frond, under side.

\section{ASPIDIUM CONIIFOLIUM.}

\section{WaLLich. KunZe.}

PLATE XXXIX. VOL. VI.

\section{Aspidium carvifolium, Polystichum coniifolium,
"،
“
aristatum,

Aspidium-The Shield Fern.
KUNZe.

Prest. J. Smith. Fee. Moore and Houlston. Of Gardens.

In the Section Polystichum of Authors.

Another very beautiful Fern, well worthy a place in every collection.

An evergreen stove species.

Native of the East Indies, the Island of Ceylon, and the Philippine Islands.

Introduced into the Royal Gardens, Kew, in 1841, by Mr. G. Gardner.

Fronds deltoid, tri-quadripinnate; the pinnules oblong-ovate, acute, pinnatifid; base cuncate, the margin having spinosemucronate teeth. The basal pinnules very large. 
Stipes fifteen inches in length, circular, very hirsute, with brown hairs, which are considerably longer near the base.

Sori large, very copious, eventually becoming confluent, covering the whole under side of the frond, almost touching each other before shedding the indusium; at first white, and when mature reddish brown.

Indusium reniform; the entire frond covered beneath with sori.

Fronds lateral, adherent to a small creeping rhizoma.

Length of frond thirty inches; width at the base fourteen inches; colour deep shining green.

My thanks are due to Mr. R. Sim, of Foot's Cray; Mr. J. Smith, of the Royal Gardens, Kew; and to Messrs. E. G. Henderson, for plants of this species; and to Mr. G. Norman, of Hull, for fronds.

It is in the Catalogues of Messrs. Sim, of Foot's Cray; E. G. Henderson, of St. John's Wood; Rollisson, of Tooting; Veitch, of Chelsea; and Kennedy, of Covent Garden.

The illustration is from a plant in my own collection. 





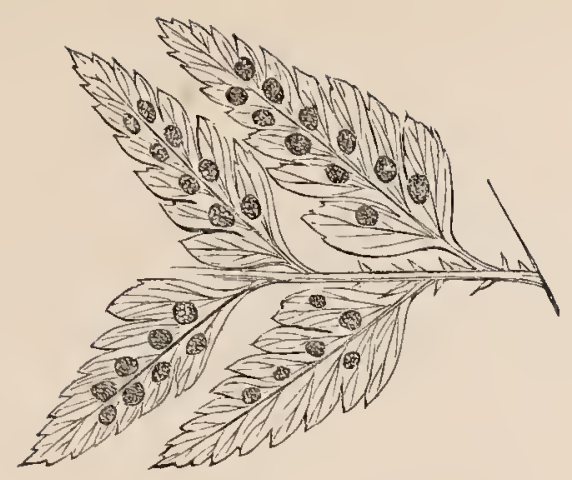

Portion of Pinna of mature Frond, under side.

\title{
ASPIDIUM CAPENSE.
}

Swartz. Willdenow.

\author{
PIATE XL. VOL. VT.
}

Tectaria coriacea,

$$
\text { “ Calahuala, }
$$

Polysticium coriaceum,

6 "

“

capense,

Rumohra aspidioides,

Aspidium coriaceum,

$\begin{array}{cc}\text { " } & \text { " } \\ " & \text { macroporum, } \\ \text { " } & \text { discolor, }\end{array}$

Polypodium argentatum,

" coriaceum,

Polypodium adiantiforme, politum,

Aspidium-The Shield Fern.
LiNk.

Cafanilles.

Roth. J. Sмith. Fee.

Schотт. Prest.

J. Smith. Moore and Houlston. RADDI.

Swartz. Schruhr. Kunze.

Langsdorff and Fischer.

Kaulfuss. Sprengel. R. Brown.

Bory.

LANGSDORFF AND Fischer.

JACQUIN.

Swartz.

Forster.

Desvaux.

In the Section Polystichum of Authors.

A WeLt-Known large-growing Fern, with a drooping habit, 
and not unfrequently found in our English collections under the name of Polypodium coriaceum, yet very different from the species figured on Plate XXXVI., and which appears to be the true plant of Willdenow.

An evergreen stove species.

Native of the Mauritius, the Cape of Good Hope, Jamaica, Brazil, Chili, New Holland, and New Zealand.

Fronds glabrous, deltoid, tripinnate; pinnules oblong-lanceolate-acute, pinnatifid, wedge-shaped at the base, and have obtuse dentate segments.

Fronds lateral, adherent to a decumbent, stout, densely scaly, cœspitose rhizoma.

Length of frond from thirty to forty inches; colour deep green. Sori large. Indusium reniform.

Introduced into the Royal Gardens, Kew, in 1823, by Mr. J. Bowie.

My thanks are due to Captain Legard, of Kirby Misperton, Yorkshire, and to Mrs. Delves, of Tunbridge Wells, for plants of this species.

It is in the Catalogues of Messrs. Sim, of Foot's Cray; E. G. Henderson, of St. John's Wood; Rollisson, of Tooting; A. Henderson, of Pine-apple Place; Veitch, Jun., of Chelsea; Cooling, of Derby; Booth and Son, of Hamburg; Masters, of Canterbury; Kennedy, of Covent Garden; and Stansfield, of Todmorden.

The illustration is from a plant in my own collection. 




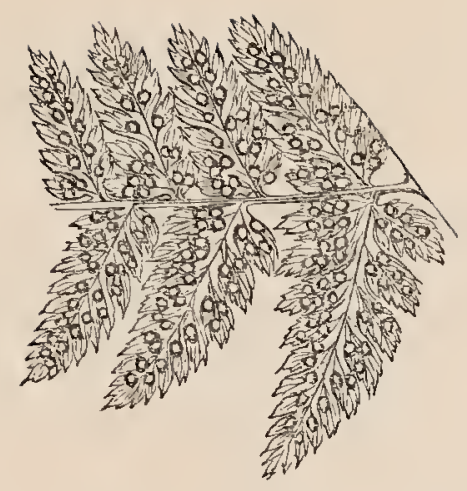

Portion of Pinna of mature Frond, under side.

\section{ASPIDIUM SPINULOSUM.}

\section{Sirartz. Schruir, (not of Willdenow.) Kunze. Link. Fee. Schott. M. S.}

PLATE XLI. VOL. VI.

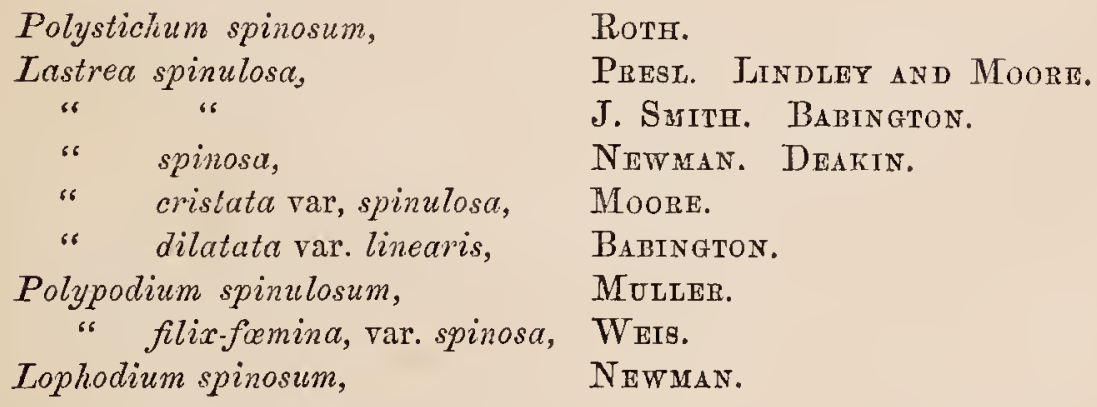

Aspidium-The Shield Fern. . Spinulosum-Prickly.

In the Section Lastrea of Autrons.

As indigenous British species, often confounded with Aspidium dilatatum, Plate XXVII., vol. vi., which some of its varied forms closely resemble.

VOL, VI. 
A hardy deciduous Fern.

Native of England.

Fronds erect; bipinnate, narrow, and ovate-lanceolate; the margins nearly parallel below, and glabrous. Pinnæ numerous; the lower ones distant and sub-opposite, the upper ones elongate, alternate, triangular, and stalked, the stalk twisted so as to make them stand nearly horizontal. Pinnules oblong, incisopinnatifid, having serrate spinose mucronate lobes.

Sori medial. Indusium entire on the margin.

Stipes having broad, ovate, pale brown scales, crowded near the base and more remote upwards.

'Terminal; adherent to a somewhat tufted rhizoma.

Length of frond from twelve to thirty-six inches; colour pale yellowish green. 


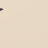




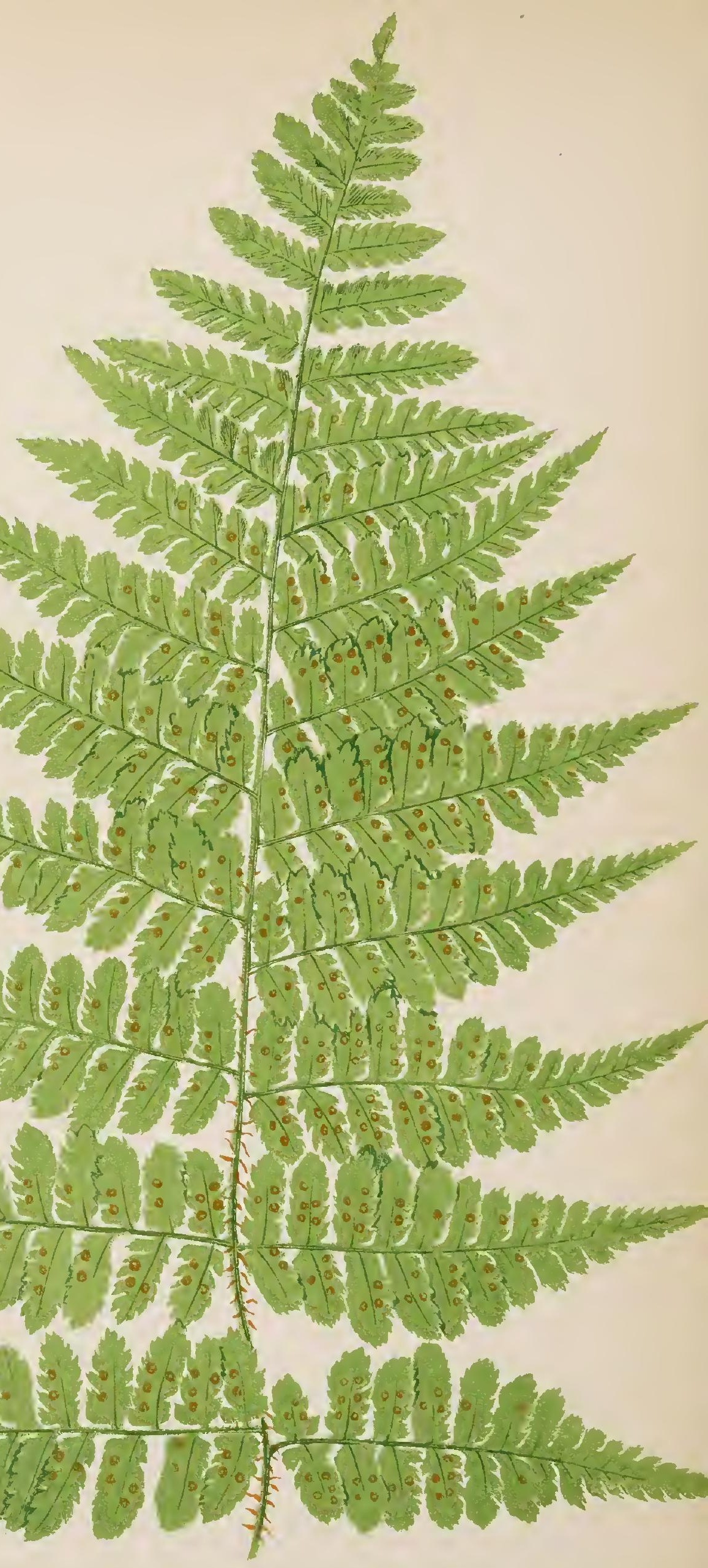






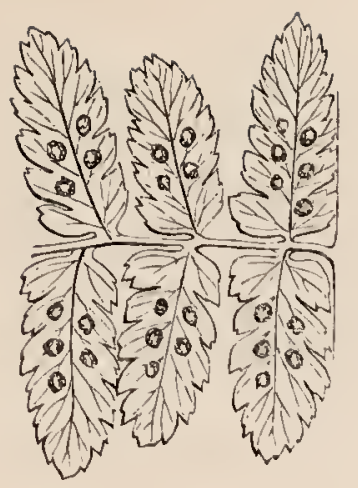

Portion of Pinna of mature Frond, under side.

\title{
ASPIDIUM CANARIENSE.
}

\author{
WILLDENOW. ?
}

PLATE XLII. VOL. VI.

$\begin{array}{ll}\text { Aspidium Ludovicianum, } & \text { HorT. } \\ \text { Lastrea Canariense, } & \text { HoRT. } \\ \text { " Ludoviciana, } & \text { HoRT. } \\ \text { Cystopteris Canariensis, } & \text { PrESL.? }\end{array}$

Aspidium-The Shield Fern. Canariense-Canary Island Fern.

In the Sectron Lastrea of Authors.

The Aspidium Canariense is an interesting very distinct Fern.

The fronds are bipinnate, membranaceous, and triangularly elongate in form; apices acuminate. Pinnæ linear-lanceolate, with acuminate apices. Pinnules oblong-ovate, basal ones pinnatifid; margin dentate. Pinnæ and pinnules distant.

Veins forked.

Sori uniserial, distant, and conspicuous. 
Stipes and rachis very scaly. Rachis creeping, and scaly; scales pale in colour.

The fronds horizontal or pendulous, widest at the base.

Length of frond twenty-four inches, of which the lower seven inches is naked. Colour dull green.

For plants and fronds I am indebted to Messis. Sim, of Foot's Cray, and Booth, of Hamburg.

A. Canariense may be procured of Mr. R. Sim, of Foot's Cray.

The illustration is from a plant in my own collection. 




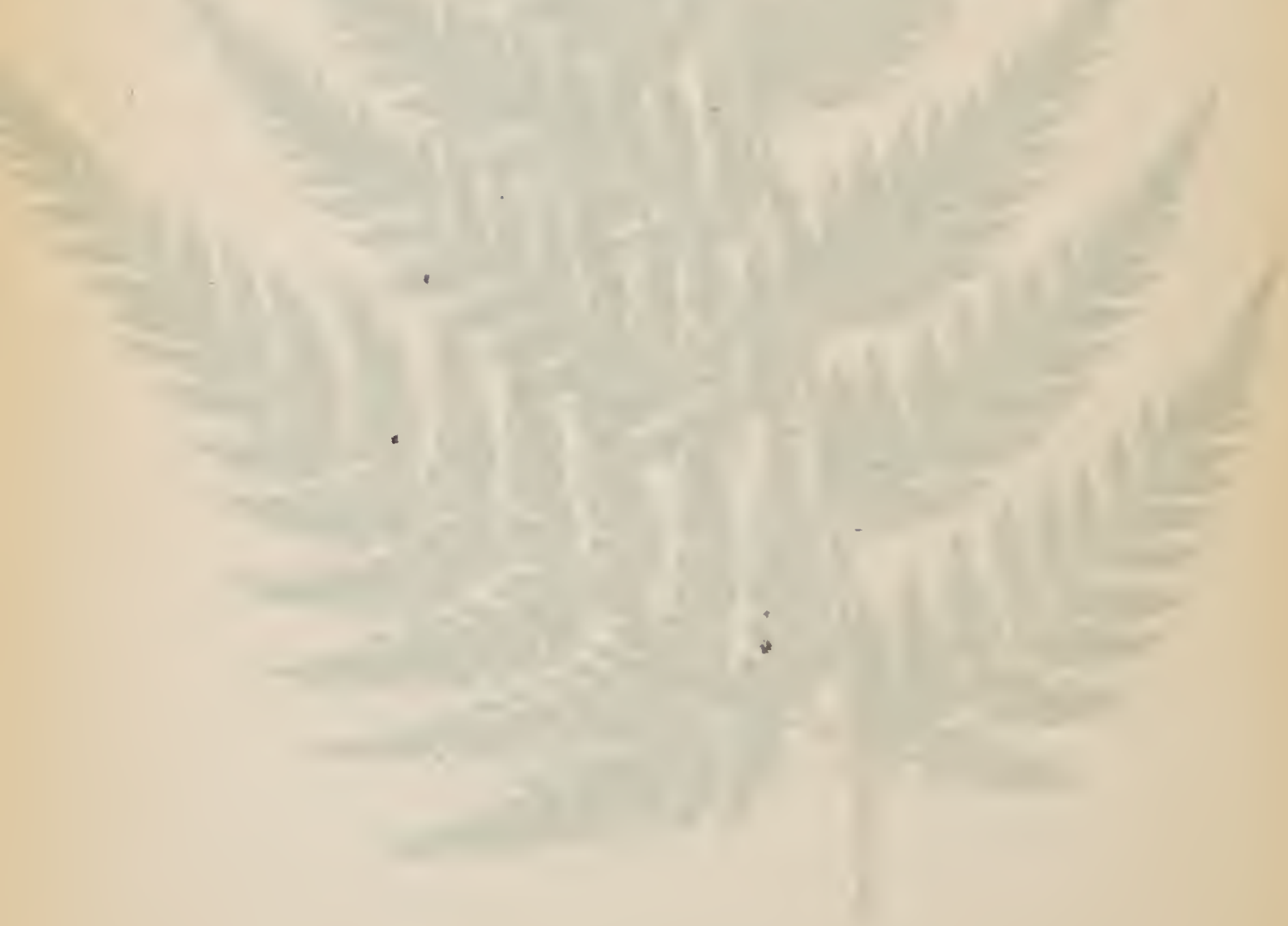




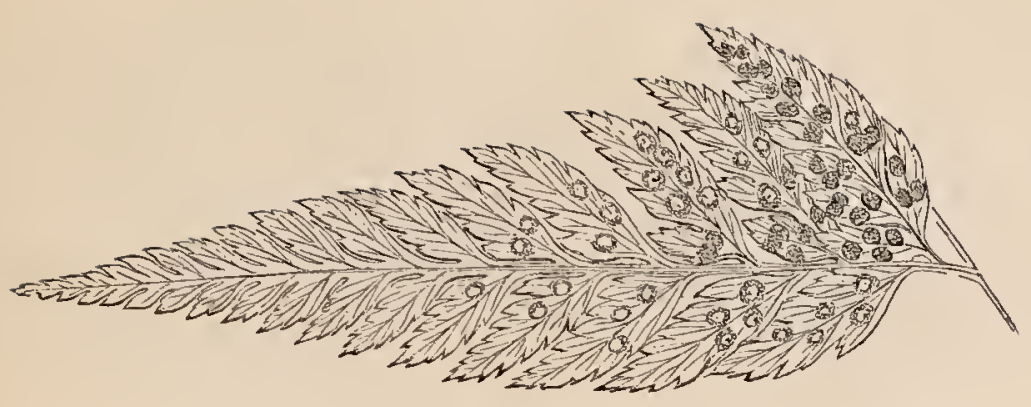

Pinna of mature Frond, under side.

\section{ASPIDIUM FRONDOSUM.}

- LOWE.

PLATE XLIII. VOI. VI.

Polystichum frondosum,

Nepírodium lata-virens,

J. Бмітг.

Lowe.

Aspidium-The Shield Fern.

Frondosum-Leafy.

In the Section Polystichum of Authors.

A magnificent Fern with rich shining grcen fronds. It is a species worthy of a place in every collection. A rare Fern. An evergreen greenhouse species.

Native of Madeira.

Fronds decompound, triangularly elongatc. Pinnulcs profoundly dentate. Pinnæ alternate, largest nearest the base; apex of pinnæ and of frond acuminate.

Rachis and stipes scaly; in the dried frond straw-coloured.

Veins branched, semi-transparent, paler in colour than the frond. 
Length of frond from two to three feet; colour a vivid, shining, rich green.

I have not as yet been fortunate enough to proeure a plant. For a frond I am indebted to Mr. R. Sim, of Foot's Cray.

It is in the Catalogues of Messrs. Sim, of Foot's Cray, and Stansfield, of Todmorden.

The illustration is from the frond sent by Mr. R. Sim, of Foot's Cray, Kent. 




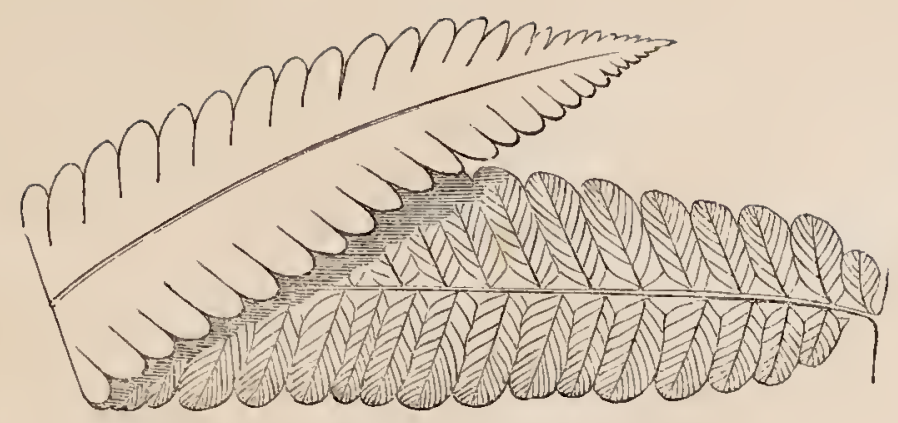

Pinna of mature Frond.

\title{
ASPIDIUM PTEROIDES.
}

\author{
SWARTZ.
}

PLATE XLIV. VOL. VT.

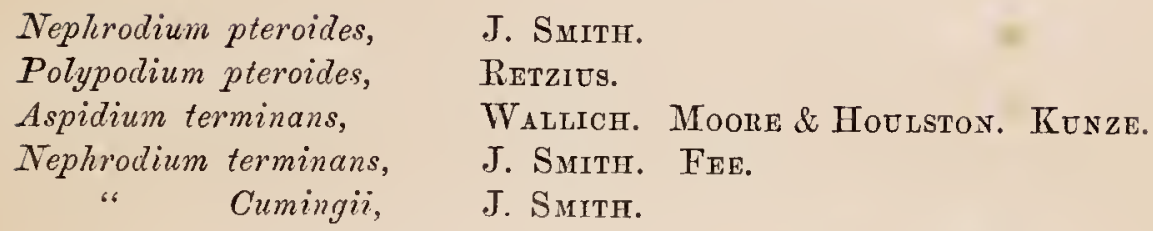

Aspidium-The Shield Fern. Pteroides-Fern-like.

In the Section Nephrodium of Authors.

Aspidium pteroides, better known as Nephrodium terminans in our British collections, is a handsome Fern, differing more especially from others in the same section in the position of its fructification.

An evergreen stove Fern.

Native of the East Indies, the Island of Ceylon, and the Philippine Islands.

Fronds pinnate. Pinnx pinnatifid, linear-lanceolate in form, petiolulate, in some degree membranous, subcordate at the base, and obtusely lobed. 
Fronds minutely pubescent on the veins on the under side. Lateral, being adherent to a slender creeping rhizoma.

Sori medial, on either side the primary veins, eventually becoming confluent; formed only along the edges of the pinnæ. Length of frond twenty-four inches; colour bright green.

Introduced into the Royal Gardens, Kew, in 1847, by Mr. G. Gardner.

For plants I an indebted to Mr.J. Henderson, of Wentworth, and to Mr. R. Sim, of Foot's Cray.

It can be procured of Messrs. Veitch, of Chelsea; Sim, of Foot's Cray; and Stansfield, of Todmorden.

The illustration is from a plant in my own collection. 


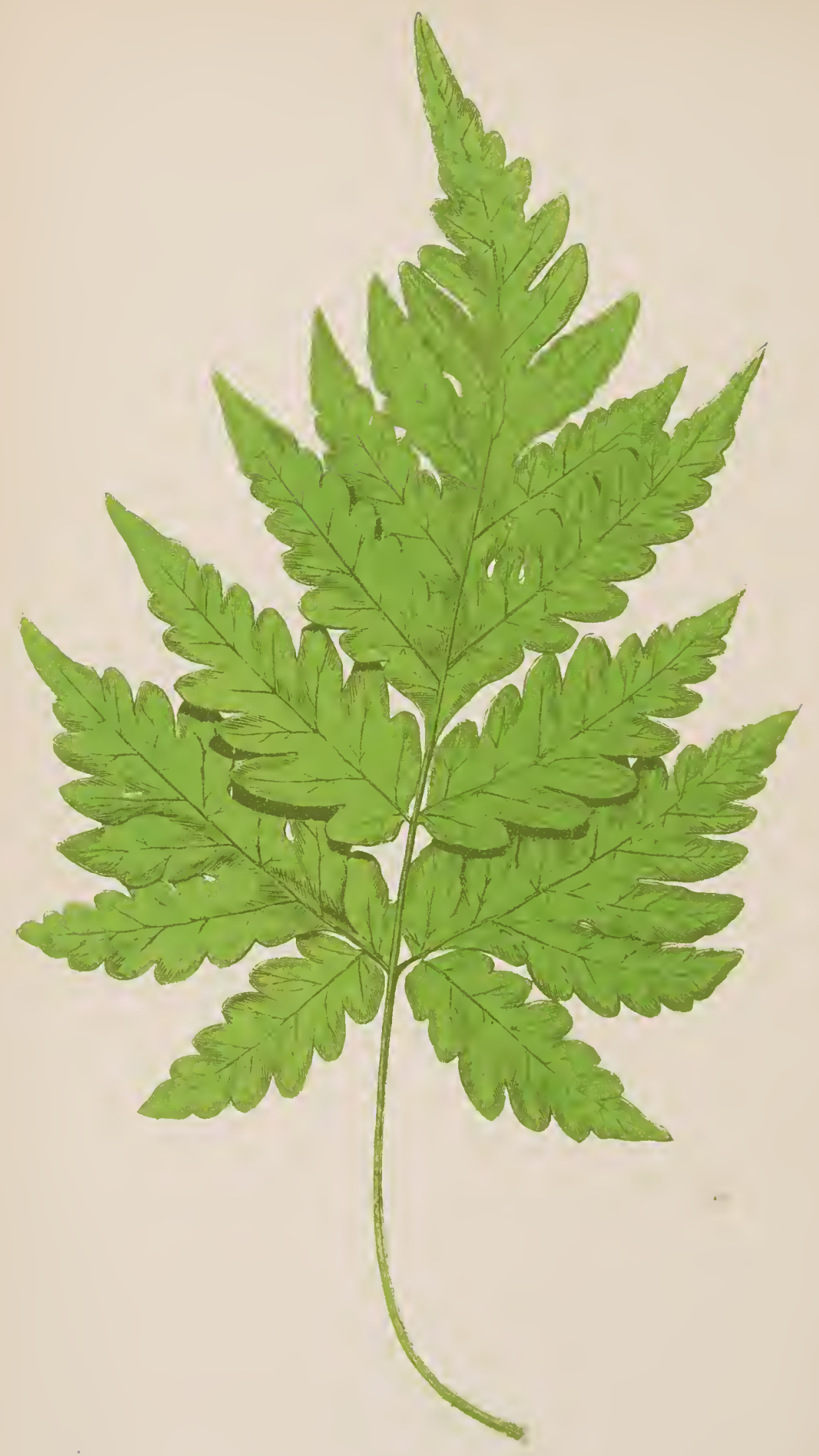

ASPIDIUM UICUTAh? M.

XLV-TOL. 



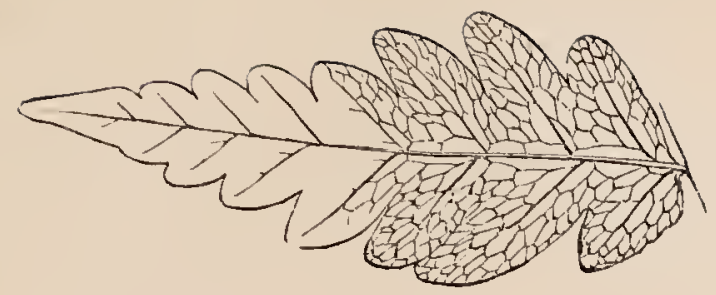

Pinna of mature Frond, upper side.

\section{ASPIDIUM CICUTARIUM.}

Swartz. J. Suith.

PLATE XLV, VOL. VI.

Polypodium cicutarium, LINNæUs.

" hippocrepis, JACQUIN.

Sagenia hippocrepis,

Aspidium hippocrepis,

" apifolium,

Prest. Moore and Houlston. Fee.

Swartz. Plumier. Kunze. Sprengel.

" latifolium,

ScHKUHR.

Prest.

Aspidium-The Shield Fern.

Cicutariam-Cow-bane-like.

In the Section Sagenia of some Authors.

A RARE handsome plant, apparcntly requiring considerable care to cultivate it successfully.

An evergreen stove Fern.

Native of Jamaica, the West Indies, Mexico, and New Grenada.

The fronds, which are glabrous, are of a triangularly-clongate form; bipinnatifid, having oblong-acuminate pinnæ, and oblongobtuse segments, with a crenate margin.

Terminal, being adherent to an erect rhizoma.

Sori produced on the apex of a free veinlet within the areoles, somewhat reniform.

VOL. VI. 
Veins pinnate; venules arcuately anastomosing, forming unequal areoles, with free veinlets.

Length of frond from twenty-four to thirty-six inches; colour light green.

Introduced into the Royal Gardens, Kew, in the year 1852, and into England in 1789.

For a frond I am indebted to Mr. R. Sim, Nurseryman, Foot's Cray, Kcnt.

It is to be procured of Mr. R. Sim, of Foot's Cray, and Messrs. Veitch, of Chelsea.

The illustration is from Mr. R. Sim's frond. 



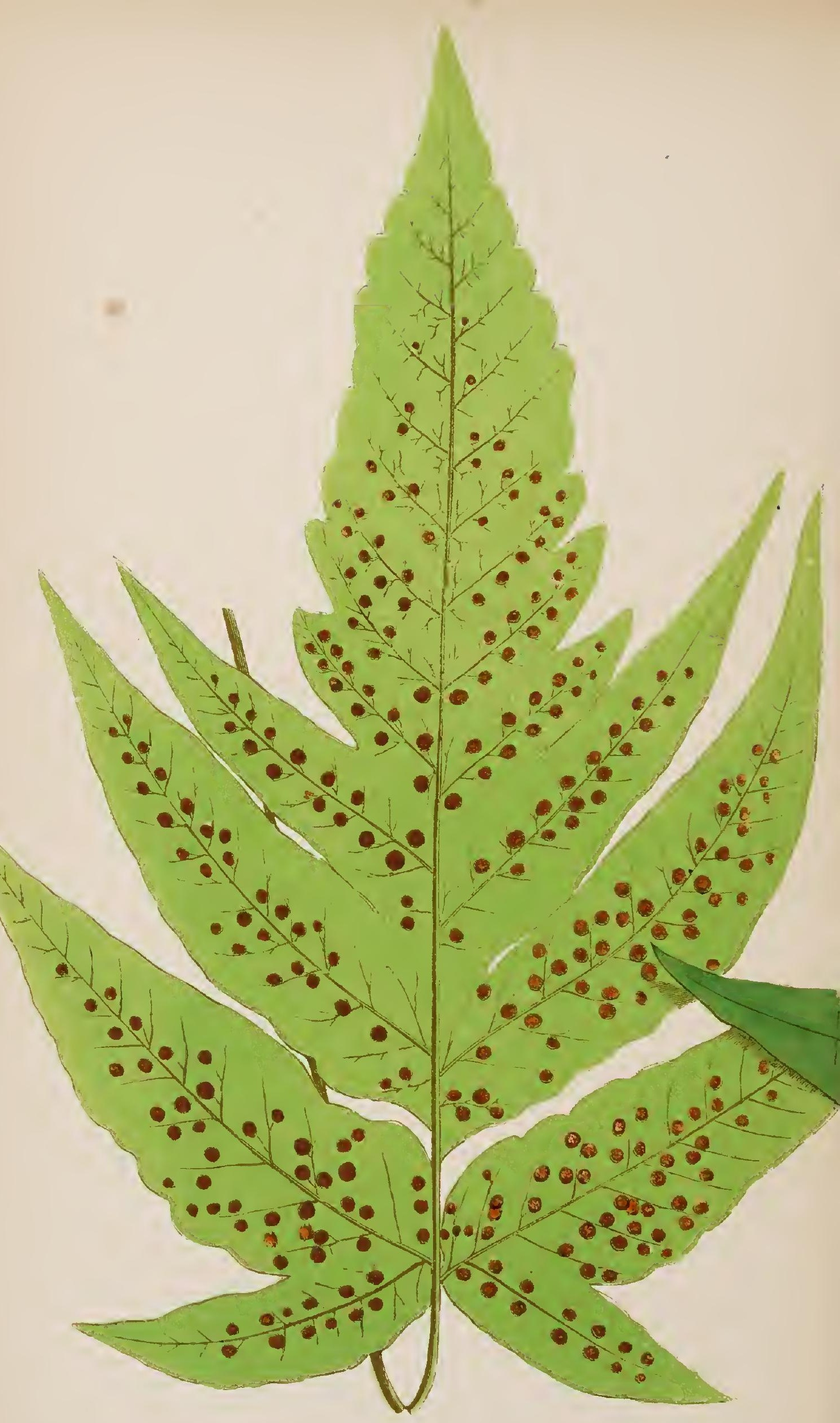






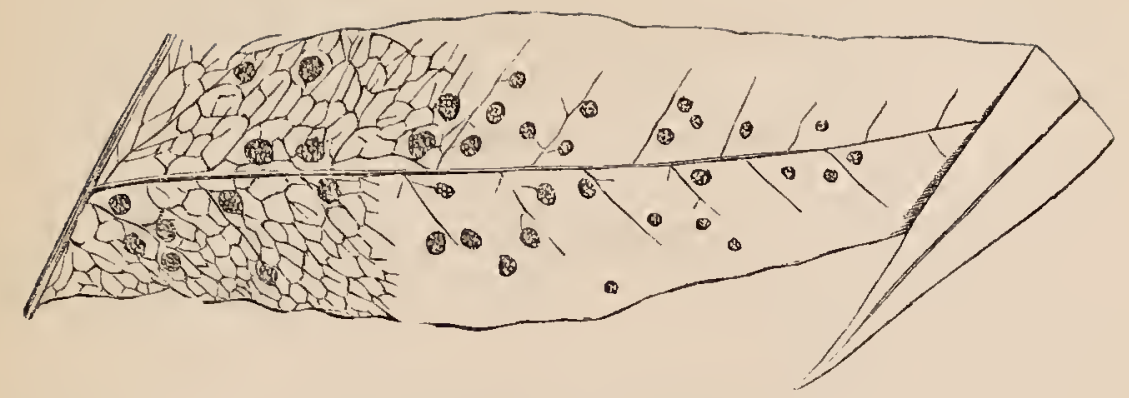

Pinna of mature Frond, under side.

\section{ASPIDIUM MACROPHYLLUM.}

\section{Swartz. Plumier. J. Simth. Moore and Houlston. Kunze. Letbiann. Willdenow. \\ Raddi. Presl. Petiver. Sprengel. Schott, M.S.}

PLATE XLVI. VOL. VI.

Cardiochlana macrophylla,

Bathmium macrophylla, Aspidium bifidum,

Polypodium variolatum,

Aspidium-The Shield Fern.
FEe.

LINK.

Presl.

Willdenow.

A FINE Fern, pretty generally cultivated in our English collections, yet often confused with Aspidium trifoliatum, Swartz, figured on Plate XXIX of this volume.

An evergreen stove Fern.

Native of the West Indies, Tropical America, and Brazil.

Fronds glabrous, oblong-ovate in form; pinnate, the pinnæ being of an oblong-lanceolate-acuminate shape, somewhat membranous, petiolulate; base cordate; the lower pair two-lobed, whilst the terminal pinna is either three-lobed or sinuately pinnatifid, the basal segments being the longest. 
Sori reniform, uniserial, on either side the primary vcins, are commonly situated on the middle of a venule.

Stipes scaly. Fronds terminal, adherent to an erect fasciculate rhizoma.

Length of frond from twenty-four to thirty inches; colour pale green.

Introduced into the Royal Gardens, Kew, in 1836, having been introduced by Messrs. Loddiges, but known in England twenty years previous.

For plants I am indebted to Mr. R. Sim, of Foot's Cray; Mr. Stansfield, of 'Todmorden; and Messrs. Booth, of Hamburg; and for fronds to Mr. R. Sim, and Messrs. Rollisson, of Tooting.

It is contained in the Catalogues of Messrs. E. G. Henderson, of St. John's Wood; Veitch, of Chelsea; A. Henderson, of Pineapple Place; Booth, of Hamburg; Sim, of Foot's Cray; Stansfield, of Todmorden; Rollisson, of Tooting; Kennedy, of Covent Garden; and Cooling, of Derby.

The illustrations are from plants in my own collection. 










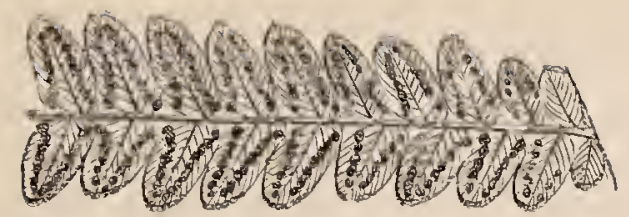

Portion of Pinna of mature Frond, under side.

\section{ASPIDIUM UNITUM.}

\section{Schkuir. Kunze. Swartz. Petiver. Burman. Sprengel.}

Plate XlViI. VOI. VI.

$\begin{array}{cll}\text { Nephrodium unitum, } & \text { R. Brown. J. SMith. SchotT. } \\ \text { " } & \text { ". } & \text { Moore ANd Houlston. } \\ \text { " } & \text { lucens, } & \text { Presl. Fee. } \\ \text { propinquum, } & \text { OF Gardens. } \\ & \text { R. Brown. }\end{array}$

Aspidium-The Shield Fern. Unitum-Joined, or linked.

In the Section Nephrodium of Authors.

THE present species is occasionally met with in collections. An evergreen stove Fern.

Native of Tropical America, New Holland, and India.

Fronds pinnate; pinne ensiform-lanceolate, from five to six inches in length, pinnatifid, with scmi-ovate acute segments. Petiolulate, and sub-cordate at the base.

Fronds glandulose; minutely pubescent beneath. Lateral; adherent to a creeping rhizoma.

Stipes, when young, of a reddish colour, and having a few scattered scales at the base.

Sori medial and uniserial. 
Lcngth of frond from eighteen to twenty-four inches; colour a brilliant shining green.

Introduced into the Royal Gardens, Kew, in 1793.

For plants of this species I am indebted to Mr. R. Sim, of Foot's Cray, and Mr. Masters, of Canterbury; and for fronds to Mr. Henderson, of Wentworth, and to Mr. Sim.

It may be procured of Messrs. E. G. Henderson, of St. John's Wood; Sim, of Foot's Cray; Masters, of Canterbury; Booth, of Hamburg; and Kennedy, of Corcnt Garden. The illustration is from a plant in my own collection. 


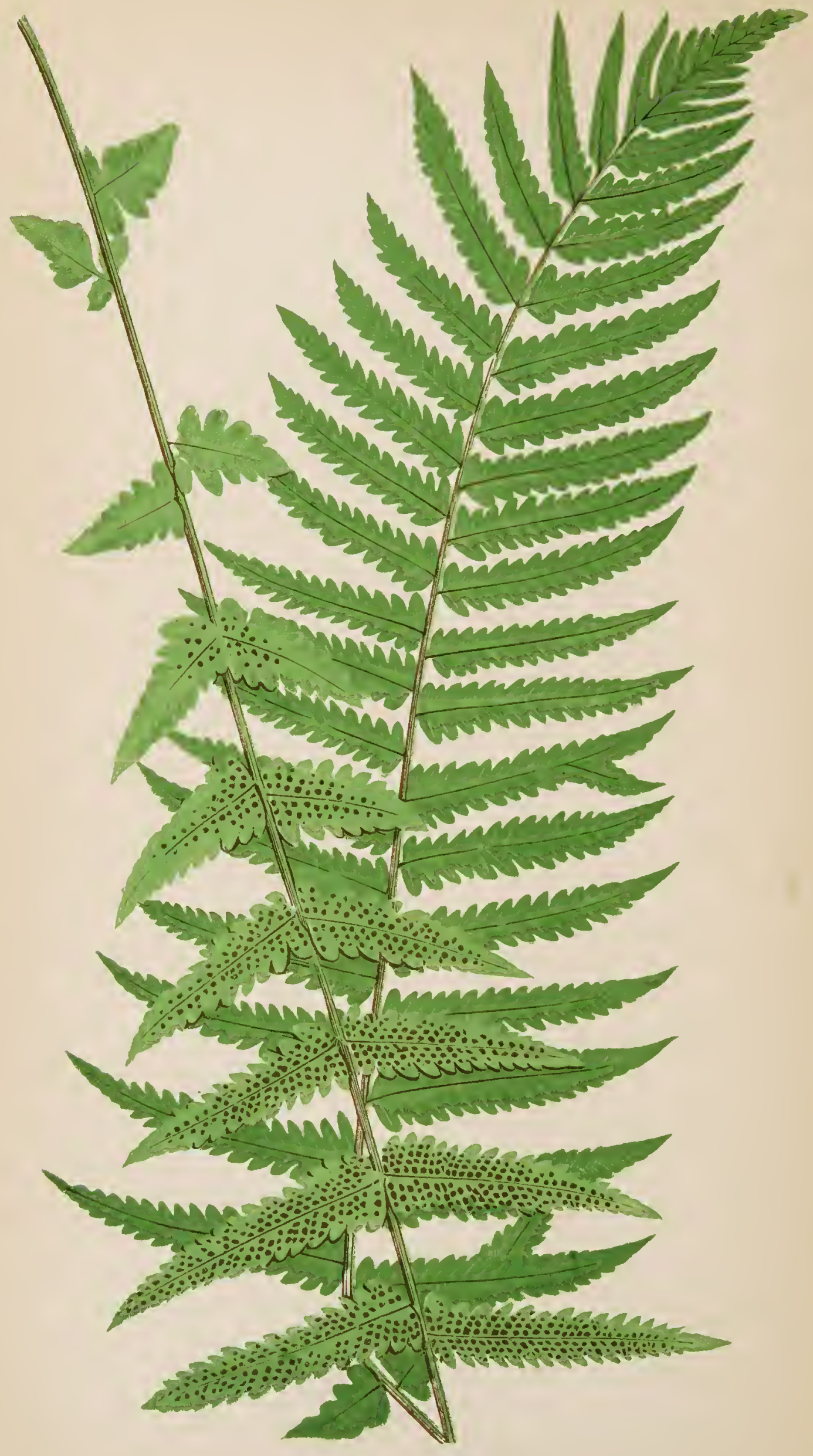






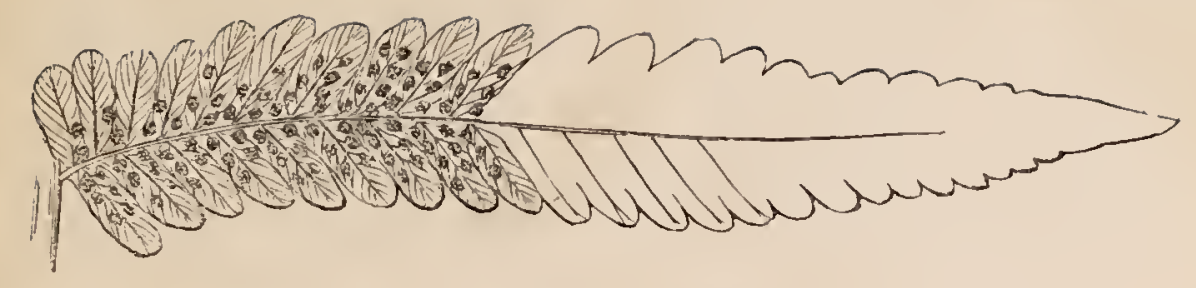

Pinna of mature Frond, under side.

\title{
ASPIDIUM HOOKERI.
}

\author{
WALLICH.
}

PLATE XLVIII. VOL. VI.

Nephrodium Hookeri, J. Sмith. Moore and Houlston.

Aspidium-The Shield Fern. Hookeri-Named after Sir W. J. Hooker, F.R.S., etc., the Director of the Royal Gardens, Kew.

In the Sectiox Nephrodium of Authors.

A Rare interesting Fern, best known as the Nephrodium Hookeri.

An evergreen stove species.

Native of the East Indies.

We are indebted to Mr. Henderson, of Wentworth, for bringing this Fern into notice.

Fronds pinnate and elongate; basal pinnæ diminutive, deltoid, deflexed, and gradually increasing in length as they ascend the rachis, being on the upper half elongate-acute, and pinnatifid, four inches long, sub-petiolate, auriculate, the base being truncate-cuneate.

Sori medial, uniserial, and scattered over the upper half of the frond. 
having a much longer stipes, and not being viviparous at the apex.

Fronds rigid, bipinnate, almost lanceolate in form, having oblong-acute pinnæ, with rather ovate pinnulcs, in some degree auriculate; base wedge-shaped, only one or two pairs are distinct, the remainder being confluent, with a sharp mucronate tooth on the apex.

Fronds terminal, adherent to a tufted rhizoma, the lower half of the frond naked.

Rachis and stipes densely clothed with narrow scales.

Length of frond from twelve to eighteen inches; colour rich dark green.

Introduced into the Royal Gardens, Kew, in the year 1842, having been received from $\mathrm{Mr}$. J. Edgerley.

My obligations are due to Mr. J. Henderson, of Wentworth, for fronds of this species.

It is in the Catalogues of Messrs. Sim, of Foot's Cray; and Kennedy, of Covent Garden.

The illustration is from a frond sent by Mr. Joseph Henderson. 



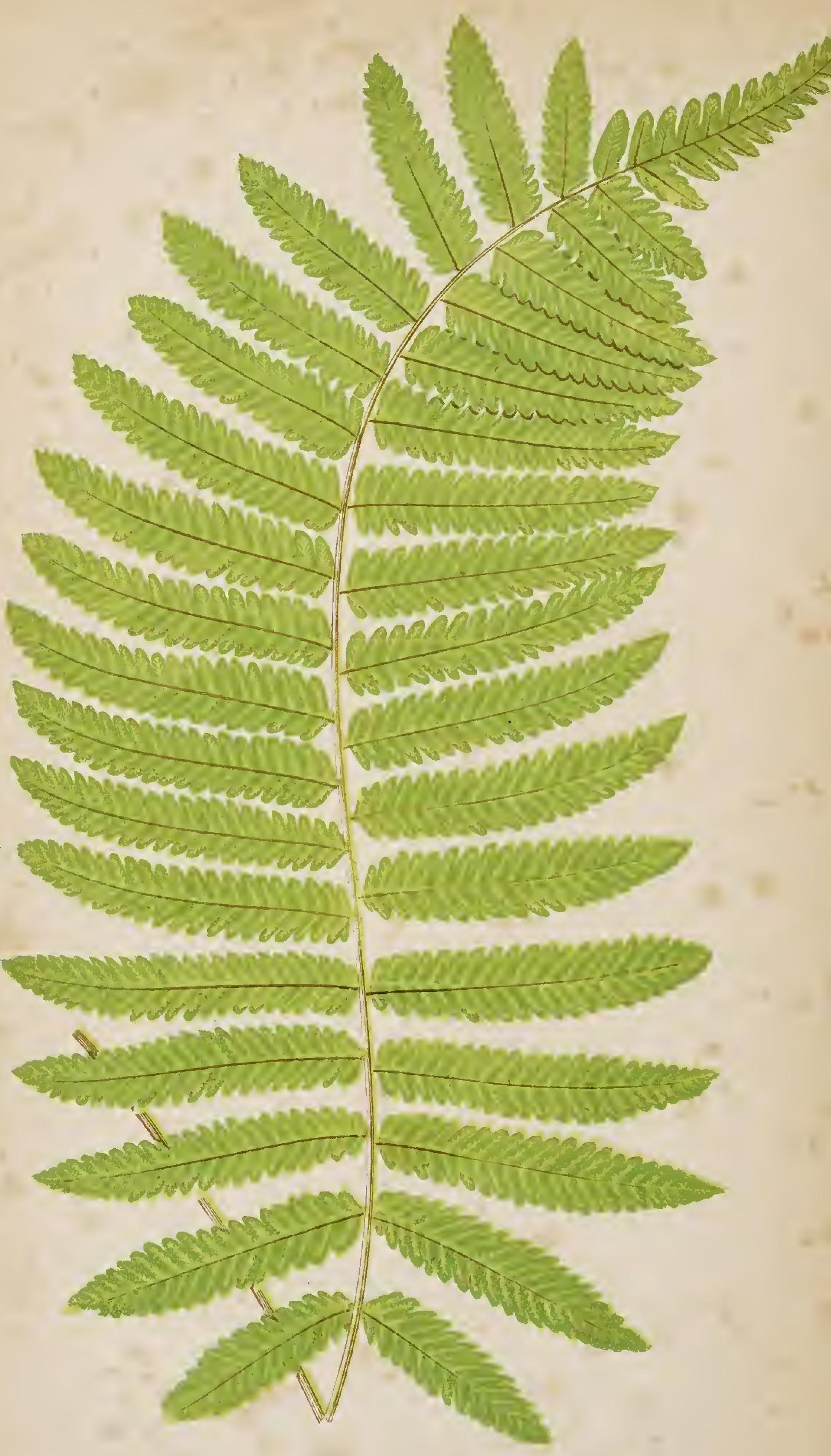

NT.1X-YOL 




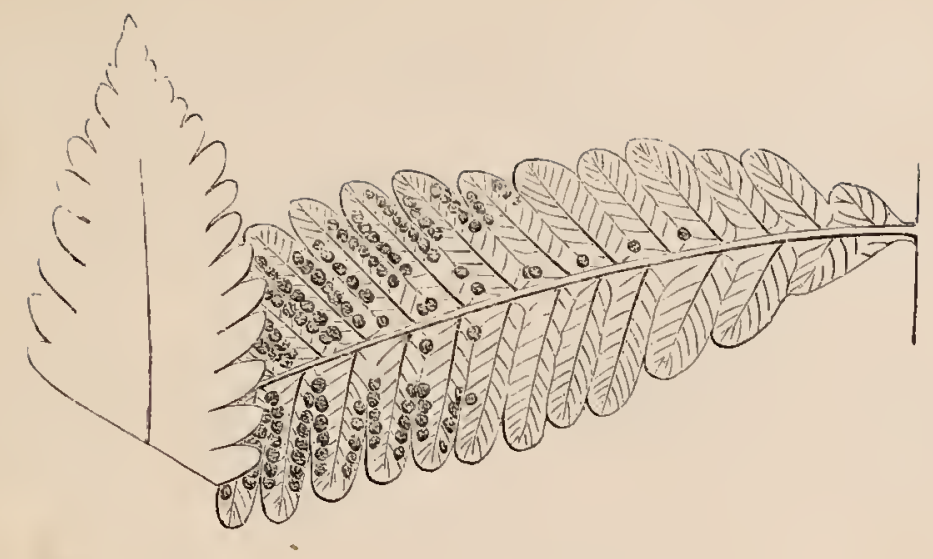

Pinna of fertile Frond, under side.

\section{ASPIDJUM ARTICULATUM.}

Lowe, (not of Swartz nor Sprenget.)

PI.ATE XIIX. VOI. VI.

Nephrodium articulatum,

Aspidium-The Shield Fern.
J. Smith. Moore \& Hodlston.

Articulatum-Jointed.

\section{In the Section Nepilrodium of Authors.}

AN evergreen stove spccies.

Native of the island of Ceylon.

Fronds glabrous, pinnatc, lanceolate in shape. Pinnx lincarlanceolate, pinnatifid, subpetiolate, bluntly wedge-shaped at the base, and articulated with the rachis.

Stipes scaly. Fronds terminal, being adhercnt to a thick creeping rhizoma.

Rachis of a pale chocolate colour.

Sori medial and uniserial.

VOL. VI. 
Length of frond from fifty to sixty inches; colour deep green.

Introduced into the Royal Gardens, Kew, by Dr. Gardner, in the year 1846.

For fronds of this Fern I am indebted to Mr. T. Moore, Curator of the Botanic Gardens, Chelsea, and to Mr. R. Sim, of Foot's Cray, Kent.

It may be procured of Messrs. Veitch, of Chelsea; $A$. Henderson, of Pine-apple Place; and Stansfield, of 'Todmorden.

The illustration is from a frond forwarded by Mr. T. Moore, of Chelsea. 



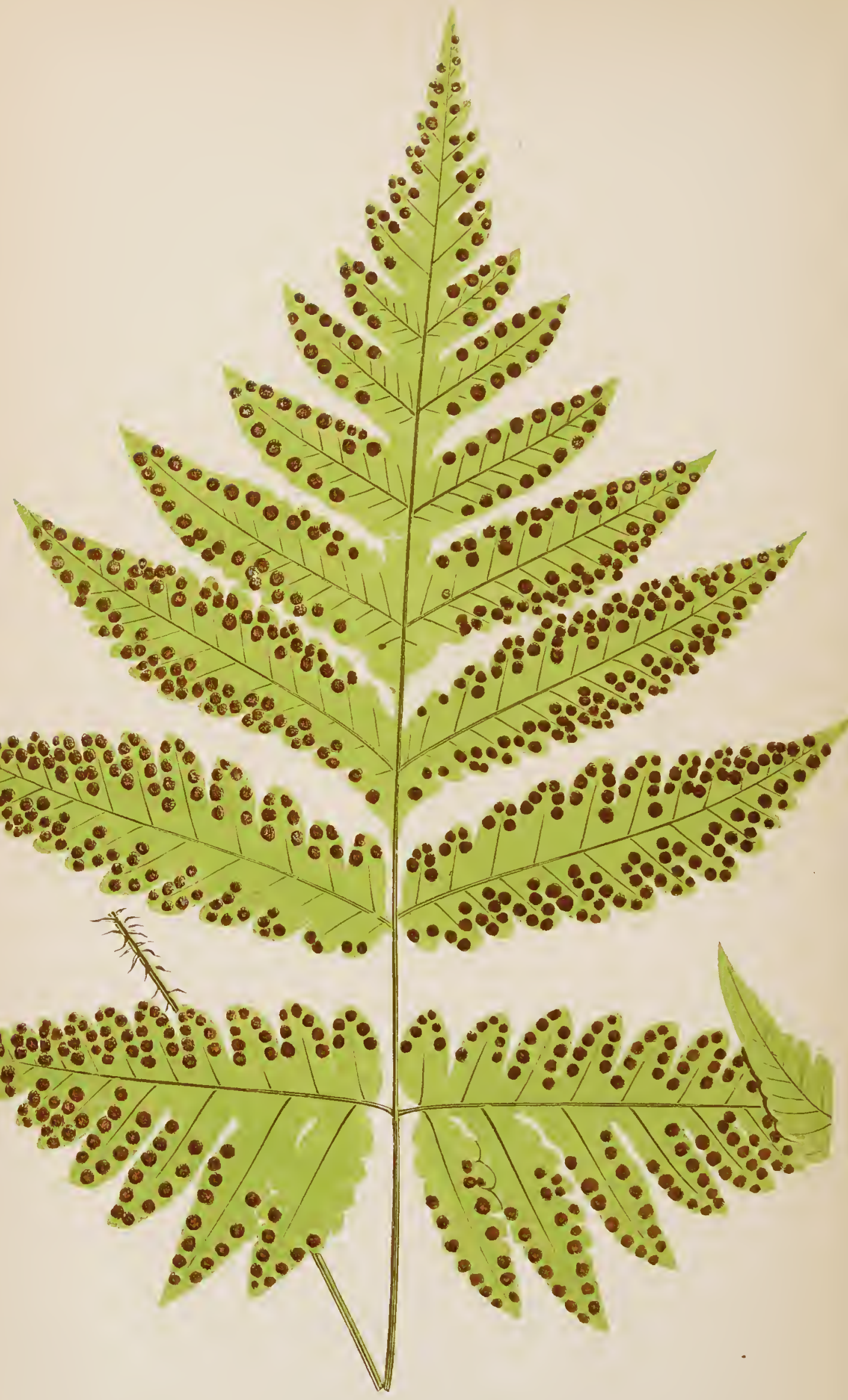





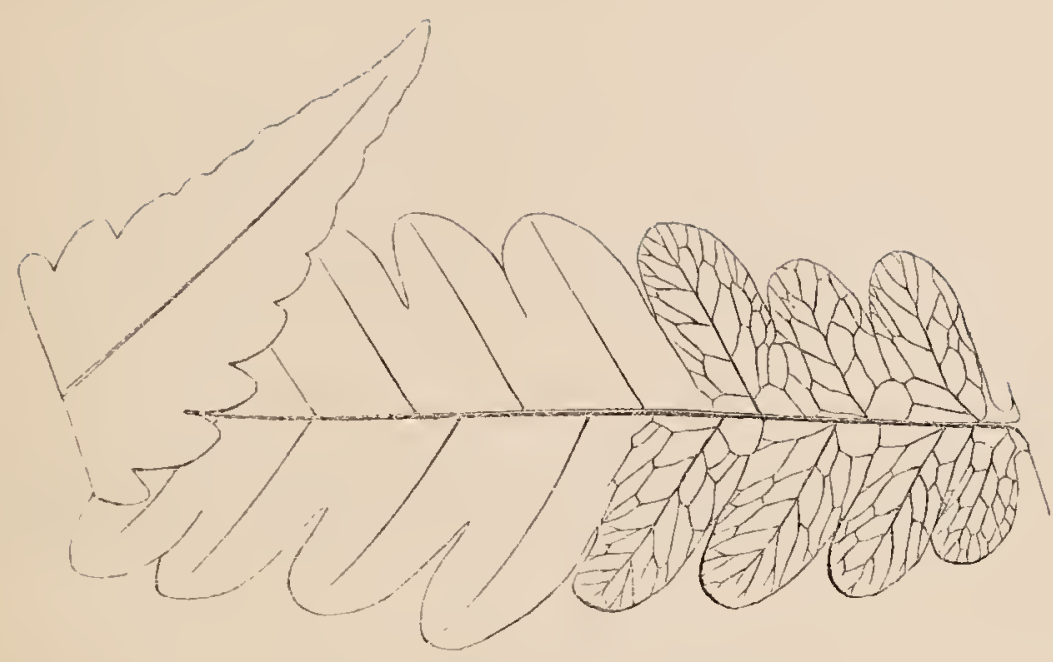

Pinna of barren Frond, under side.

\section{ASPIDIUM COADUNATUM.}

Waldicil. Hooker axd Greville. J. Shitil. Kunze.

PLATE I. TOL. VI.
Sagenia coadunata, J. Smitu. Moome and Houlston.
" hippocrepis, Presi, (not of Swartz.)
"Macrodonta, FEE.

Aspidium-The Shield Fern. Coadunatum-United.

In the Section Sagenia of some Authors.

As evergreen stove Fern.

Native of the East Indies and the island of Ceylon.

Fronds glabrous, bipinnate, triangularly-elongate in form; the pimn also triangularly-elongate, acuminate, the inferior pinuules 
being far apart; superior pinnules pinnatifid, having a profoundcrenate edge, and a decurrent base.

Sori somewhat reniform.

Veins pinnate, the venules anastomosing.

Fronds terminal, adherent to a stout, scaly, and somewhat creeping rhizoma.

Stipes at the base thickly scattered over with narrow scales.

Length of frond from twenty-four to thirty-six inches; colour pale green.

Introduced into the Royal Gardens, Kew, in 1845, by Mr G. Gardner.

My thanks are due to Mr. J. Henderson, of Wentworth, for a plant of this Fern; and to Mr. R. Sim, of Foot's Cray, for fronds.

It is in the Catalogues of Messrs. Veitch, of Chelsea; Sim, of Foot's Cray; and Booth, of Hamburg.

The illustration is from a frond forwarded by Mr. R. Sim. 


\section{GLOSSARY FOR VOL. VI.}

[The present Glossiry contains deseriptions of such terms as are not deseribed in the other volumes. It must be therefore considered as a continuation of those given in the other volumes.]

Alternate.-When apparently disposed without regularity; thus alternate pinnæe are when the pinnæ are not opposite to cach other.

Antcrior-Plaeed in front of others, or outwardly with respeet to the axis about which they are arranged.

Arborescent.-The form of a tree. Thus an arboreseent caudex has a tree-like stem.

Aristate -Awned.

Bacciform.-Bearing berries, or haviug a suceulent nature like that of berries.

Ciliato-serrate-When marginal serratures have stiffish hairs.

Circlet.-Plaeed in a ring.

Channelled.-Hollowed out, resembling a gutter.

Cordate-auriculatc-Having heart-shaped ears

Costoform.-Rib-shaped.

Cuculate-IIooded. Where the edges are curved inwards, or rolled up like the point of a slipper.

Dccumbent.-Reelining upon the ground, and rising again from it at the apex.

Dopanperated.-Empoverished. When the branehes or segments are almost wanting.

Excurrent.-Extending beyond the usual limits.

Eccentric.-Not having the same centre.

Fascicled.-Where several similar parts originate at the same spot, and are eolleeted together as in a bundle.

Glandular.-Furnished with glands.

Inciso-lobate.-Lobes deeply eut, or divided.

Inciso-pinnatifid.-So deeply cut as to approach a pinnate form.

VOL. VI. 
Indigenous.-Belonging to a plaee. Thus, indigenous to England, is belonging to England.

Inferior-Below. Thus, inferior base is the lowest base.

Mheronate-Abruptly pointed by a sharp, stiff, spinous point.

Normal.-Typical or ordinary form. Thus, normal form does not deviate from the ordinary form.

Obsolete.--Disused.

Orbieular-Cireular, or round.

Ovate-faleate.-Of a eurved, oval, or egg-shaped form.

Paleaceous.-Chaffy. Thus, a paleaeeous rachis is when the raehis is very sealy.

Peltate.-Fixed to the stalk by the eentre, or by some point within the margin, i.e, not at the edge. The attachment of the stalk to the leaf of the Iropceolum is a familiar illustration.

Petiolate.-Furnished with a petiole or stalk.

Petiolulate.-When the leaflets are stalked.

Persistent.-Remaining beyond the ordinary period.

Repand.-Having an uneven slightly wavy margin.

Semi-ereet.-Partly ereet.

Sinuately-pinnatifid.-Unevenly pinnatifid, alternately with deep eoncavities and eonvexities.

Sub-falcate- -The word sub means somewhat, or a near approach to the term to whieh it is appended. Thus, sub-faleate is seareely eurved, or eurved in a slight degree.

Sub-marginal.-Almost marginal.

Sub-rhomboidal.-Almost rhomboid.

Squamulous.-Covered with small scales.

Superior base.-Upper base.

Triangulcr.7y-elongate- $-\Lambda$ lengthened triangular form.

Tri-quadripinnate.-Three times quadripinnate.

Tomentum.-Short elosely-matted hairs, or woolly pubescence.

Timeate-dimidiate.-Imperfeetly truncate.

Trapezio-oblong.-A lengthened trapezoidal form.

Umbilieate-Having a depression in the centre. Also with an elevation in the eentre. Known as a boss.

Undulated.-Wary. 


\section{INDEX TO VOL. VI.}

[Those Ferns laving an authority attnehed, are the respective names adopted in this Worl, of which a deseription, together with a Coloured Illustration and one or more Woodents, is given. Names not having an autherity attached, are those adopted by other antlors, and are therefore to be found under otber names.]

\begin{tabular}{|c|c|}
\hline \multirow{7}{*}{$\begin{array}{lrr} & & \text { PAGE. } \\
\text { Acrostichum thelypteris } & & 55 \\
\text { Adiantum fructicosum } & \cdot & 19 \\
\text { lunulatum . } & \cdot & 19 \\
\text { Aspidium aculcatum. Swartz } & 23, \\
49,50,51,67,68\end{array}$} & \multirow{6}{*}{$\begin{array}{rr} & \text { PAGE. } \\
\text { Aspidium angulare var.præmorsum } 69 \\
\text { var. proliferum } 69,70,71 \\
\text { var. sub-tripinnatum } & 69, \\
& 70,71 \\
\text { var. tripinnatum } & 70,71\end{array}$} \\
\hline & \\
\hline & \\
\hline & \\
\hline & \\
\hline & \\
\hline & apifolium . \\
\hline var. lobatum-incisum & argutum \\
\hline var. lonchitidioides & articulatum. Love . 125 \\
\hline var. multifidum & asperum \\
\hline var. proliferum & augescens. Link \\
\hline acuminatum. Willdenow 37 & auriculatum \\
\hline acrostichoides. Swartz & bifidnm \\
\hline affine & Boothii \\
\hline angulare. Kitaibel 23,50, & Braunii $\cdot \quad \cdot \quad \cdot \quad 67$ \\
\hline $51,67,68$ & Canariense. Willdenow 111, \\
\hline var. acutum & 112 \\
\hline var. alatum & earvifolium \\
\hline var. angustatum & capense. Swartz . 100, 107 \\
\hline aristatum & cicutarium. Swartz \\
\hline var. biserratum & coadunatum. Wallich \\
\hline rar. decompositum & coniifolium. Wallich \\
\hline var. depauperatum & eoriaceum. Love . 99, 107 \\
\hline var. dissimile & cristatum. Swartz \\
\hline var. hastulatum & 60,61 \\
\hline var. imbricatum & var. callipteris \\
\hline var. incisum & cultratum . \\
\hline var. intermedium & decompositum. Kunze 73,95 \\
\hline var, irregulare $\quad . \quad .69$ & decurrens. Lowe $\quad 25$ \\
\hline var. multifidum $\quad . \quad 68$ & decursive-pinnatum \\
\hline
\end{tabular}




\begin{tabular}{|c|c|c|}
\hline dium depastum & $\begin{array}{r}\text { I'AGE. } \\
41\end{array}$ & Aspidium lunulatum \\
\hline $\begin{array}{l}\text { idium depastum } \\
\text { dilatatum. Swartz }\end{array}$ & $77,78,80$ & lobatum . \\
\hline var. alpinum & . 78,80 & var. lonchitidioides \\
\hline var. angustum & 78,80 & maerophyllum. Swartz \\
\hline var. Chanterix & 78,80 & macroporum \\
\hline var. collinum & 78,79 & marginale. Swartz \\
\hline var. dumetorum & 78,79 & molle. Swartz. \\
\hline var. glandulosum & 78,80 & mucronatum. Swavtz . 91 \\
\hline var. nanum . & 78,79 & munitum . \\
\hline var. Tanaeetifoliu: & m 77, 78 & nemorale \\
\hline & 79 & neradense \\
\hline diseolor & 107 & noveboracense \\
\hline discretum & 49 & ocellatum . \\
\hline Donianum & 42 & odorifcrum \\
\hline dumetorum & . 78 & oligodonton \\
\hline elongatum. Swartz & $z .75$ & oreopteris. Suartz \\
\hline erosum . & 77,78 & ottonianum . . \\
\hline falcinellum. Swart & 29 & paleaceum \\
\hline faleaium. Swartz & 33 & pallidum \\
\hline filix-mas. Swartz & 23,41 & palustre. \\
\hline & $47,61,75$ & patcntissimum \\
\hline var. ineisum . & . 41 & pica . \\
\hline var. paleacenm & - 41,42 & Plukenetii \\
\hline var. pumilum & 47 & podophyllum. Hooker 97,98 \\
\hline var. recurrum. & & proliferum. Brown \\
\hline $\begin{array}{l}\text { (See Lastrea filix } \\
\text { varicties.) }\end{array}$ & -mas for & $\begin{array}{l}\text { pubeseens. Surartz } \\
\text { pulcherrimum }\end{array}$ \\
\hline fœniseeii & 79 & pumilum. Lowe \\
\hline fragrans $\quad . \quad$. & 63 & 48,89 \\
\hline frondosum. Lowe & 113,138 & pungens. Kaulfuss \\
\hline glabellum. Lowe & . 93 & pteroides. Slcartz \\
\hline Goldianum. Fee & - 83 & rigidum. Swartz \\
\hline Goldieanum . & . $\quad 59,83$ & scmicordatum. \\
\hline hastulatum & & serra. \\
\hline licracleifolium & $\cdot 85$ & Sieboldi \\
\hline hippocrepis . & . 117 & spinulosum. Swartz \\
\hline Hookeri. Wallich & 123 & $61,77,78,79,80,109$ \\
\hline inxquale . & 111 & var. uliginosum \\
\hline intermedium & . 50 & squamatum . \\
\hline lancastriense & . $\quad 59$ & squimosum \\
\hline latifolium & .117 & terminans \\
\hline lentum . & . 50 & thelypteris. Swartz 55, 89 \\
\hline lonehitis. Swartz & . 65 & thelypteroides. Sirartz 89 \\
\hline var. multifidum & . $\quad 66$ & trifoliatum. Sicartz. S5 \\
\hline var. proliferum & . 60 & truncatulum \\
\hline Ludovicianum . & . $\quad 111$ & truncatum \\
\hline
\end{tabular}






Cyrtomium falcatum . 33,34

Cystoptcris Canariensis . 111

Dichasiun patentissimum

Didymochlæna truncatula. J. Smith

19,20

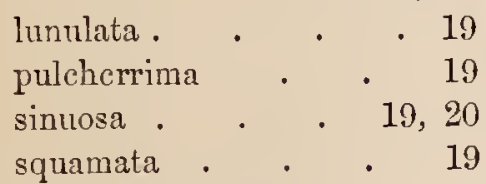

Diplazium pulcherrimum . . 19

Dryopteris abbreviata . . 47 affinis . . . . 41

Borreri • . . 41

cristata . . . . 59

dilatata . . . 77

filix-mas. . . . 41

var. abbreviata . 47

thelypteris . . . 55

Fadyenia prolifera. Hooker 11

Hemestheum montanum . . 53

thelypteris . . . 55

Hypopeltis lobulata . • . 67

Lastrea acuminata . . 37

aflinis . . . . 41

alpina. . . . 78

augescens . . . 35

callipteris . . $\quad 59$

Canariense . . . 111

Chanteriæ . . 78

collina . . . . 78
Lastrea cristala $\quad$. $\quad 23,59$

cristata major . . 61

var. spinosa . . 109

var. uliginosa • . 59

decurrens . . 25,26

decursive-pinuala . 25,26

decomposita • $\quad 95$

dilatata . 23, 77,80

var. alpina $\quad \cdot \quad 81$

var. angusta . 78, 80

var. Chanteria . 81

var. collina . 78, 80, 81

var. deltoidea. . 80

var. distans . . 81

var. dumetorum . 80, 81

var. fuscipcs . . 80

var. glandulosa . 78,80

var. lincaris . . 109

var. micromera - 80

var. maculata . . 78

var. multifida . $\quad 80$

var. nana . $78,80,81$

var. obtusa . $\quad 81$

var. pumila . . 80

var. Schoficldii . 81

var. Smithii . . 80

var. tanacetifolia . $\quad 80$

var. vallida . . 81

elongata . . . 75

erosa . . . . 41

filix-mas . . . 23, 41

yar, abbreviata . 43,47

var. affinis . . 43

var. Borreri . . 42

var. crispa . . 45

var. cristata $42,43,44$,

45,46

var. dcorso-lobata 43, 44

var. dichotoma . . 43

var. erosa . . .43, 44

var. incisa . $\quad 43,45$

var. multifida . . 42,43

var. paleacea $42,44,45,46$

var. polydactyla $43,44,45$

var. producta . . 43

var. prolifera . . 43 
Lastrea filix-mas, var. pseudo-mas 42 var, pumila . . 43

var. reculvum . 43

var. subinterra . 43,47

var. triangularis . 43

glabella . . . . 93

glandulosa . . . 78

Goldiana . . . 83

Ludoriciana . . 111

marginalis . . . 27

maculata . . . 78

multiflora . $\quad 23,77$

var. collina . . 78

var. dilatata . . 77

var. nana . . 78

montana . . . 53

noveboraeense . $\quad 89$

oreopteris . . 23, 53

var. erispa . . 54

var. truneata . . 54

paleaeea . . . 41

patentissima . . . 41

podophylla . . . 97

pumila . . . . 47

var. abbreviata . 47, 48

var. subintegra . 47,48

pubeseens . . . 73

reeurva . . . 23

rigida. . . 23,63

Rileyana . . . 37

serra . . . . 35

Sieboldi . . . . 97

spinosa . . . 109

spinulosa . . 23, 109

thelypteris . . 23,55

thelypteroides . . 89

uliginosa . . . 59,61

vestita . . . . 103

villosa . . . 101

Lephodium abbreviatum . . 47

eallipteris . . . 59

collinum . . . 78

erosum . . . 41

filix-mas . . . 41

glanduliferum . . 78

glandulosum . . . 78
PAGE.

Lephodium multifiorum var. nana 78

rigidum . . . 63

spinosum . . . 109

uliginosum • . $\quad 59$

Lepidonevron aeuminatum . 37

Nephrodium artieulatum . 125

aerostiehoides . . 57

eristatum . . 59

Cumingii . . . 115

decompositum . . 95

glabellum • • . 93

Goldianum . . . 83

Hoolieri . . . 123

læta-virens . , 113

lneens . . . . . 121

molle . . . 87

marginale . . .27

ottonis . . . 35

pallidum . . . 63

propinquum . . 121

pteroides . . . 116

pubeseens . $\quad .73,87$

Sloanei . . . . 91

terminans . . . 115

thelypteris . . . 55

thelypteroides . . 89

unitum . . . . 121

Onoelea obtusiloba . . 7,8

obtusilobata. . . 7

sensibilis. Linnaus . 7

Phanerophlebia neplnrolepis . 15

Phegopteris deeursive-pinnatum 25

Polypodium aeuleatum $31,49,67$

adiantiforme . . 107

angulare • . . 67

appendieulatum . $\quad 67$

argentatum . . 107

aristatum . . . 78

eadueum . . . 15

eallipteris . . . 59

eieutarium . . . 117

eoriaceum . . . 107

eristatum . . . 59, 77

deeursive-pinnatum $\quad .25$

dilatatum . . . 77

elongatum . . . 75 


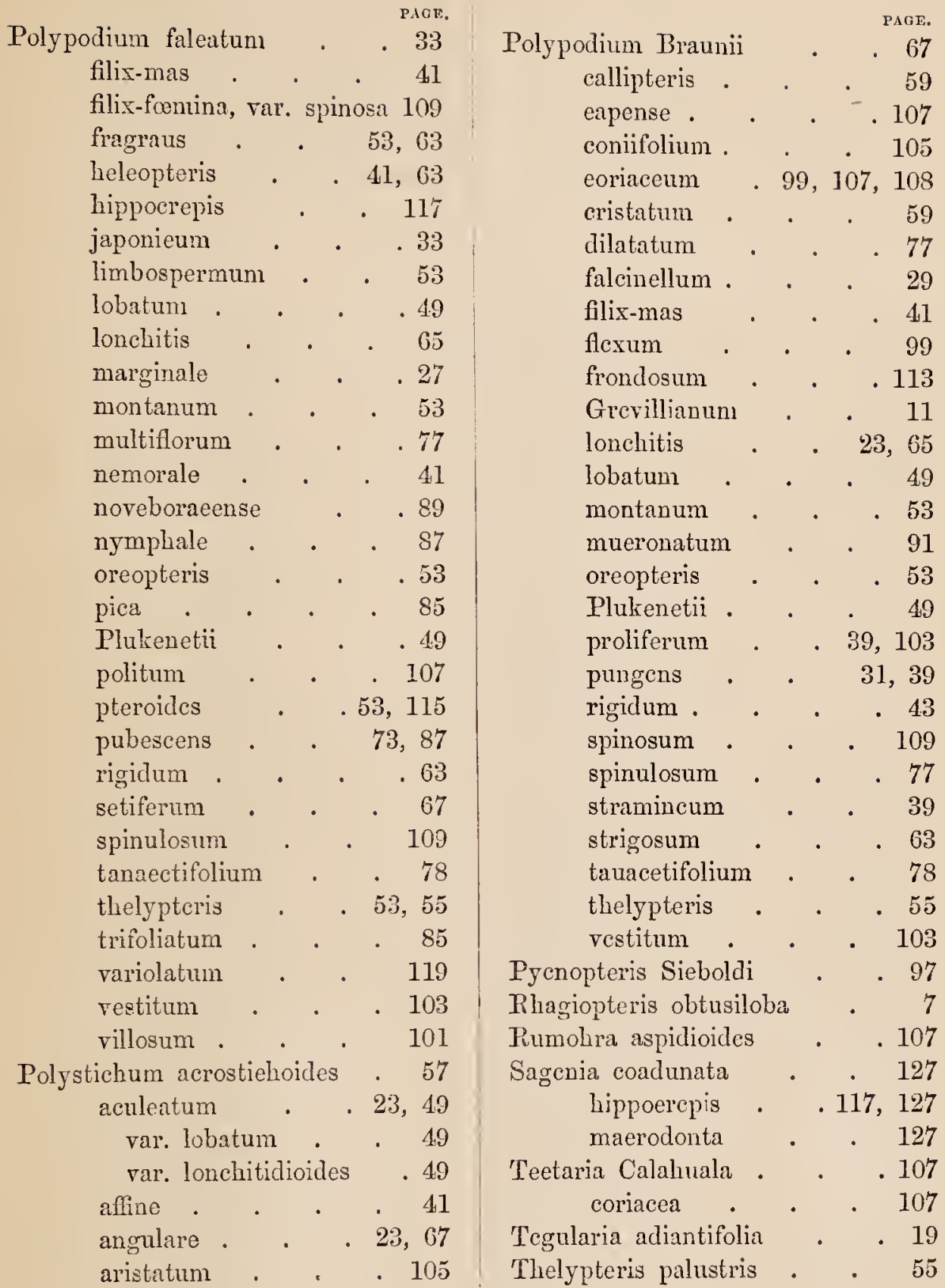




\section{AUTHORITIES QUOTED IN VOL. VI.}

\begin{tabular}{|c|c|c|}
\hline $\begin{array}{l}\text { Aiton. } \\
\text { Allchin. } \\
\text { Allioni. } \\
\text { Arnott. } \\
\text { Arrab. } \\
\text { Babington. } \\
\text { Baird. } \\
\text { Balfour. } \\
\text { Bauer. } \\
\text { Boissier. } \\
\text { Bolton. } \\
\text { Bory. } \\
\text { Borie. } \\
\text { Bower. } \\
\text { Börkhausen. } \\
\text { Braun. } \\
\text { Brown. } \\
\text { Burmann. } \\
\text { Cameron. } \\
\text { Cavanilles. } \\
\text { Chanter. } \\
\text { Choules. } \\
\text { Cunningham, } \\
\text { De Candolle. } \\
\text { Deakin. } \\
\text { Desvaux. } \\
\text { Döll. } \\
\text { Don. } \\
\text { Edgerley. } \\
\text { Elwortliy. } \\
\text { Ehrlart. } \\
\text { Fée. } \\
\text { Fischer. } \\
\text { Forskal. } \\
\text { Forster. } \\
\text { Francis. } \\
\text { Fries. } \\
\text { Gardner. }\end{array}$ & $\begin{array}{l}\text { Gray. } \\
\text { Greville. } \\
\text { Hoffmann. } \\
\text { Hooker. } \\
\text { Houlston. } \\
\text { Houttuyn. } \\
\text { Hudson. } \\
\text { Humboldt. } \\
\text { Jacquin. } \\
\text { Johnson. } \\
\text { Kaulfuss. } \\
\text { Kinahan. } \\
\text { Kitaibel. } \\
\text { Kunze. } \\
\text { Langsdorff. } \\
\text { Ledebour. } \\
\text { Leibmann. } \\
\text { Leighton. } \\
\text { Lindley. } \\
\text { Link. } \\
\text { Linnæus. } \\
\text { Loiseleur. } \\
\text { Lowe. } \\
\text { Lowe, E. J. } \\
\text { Mackay. } \\
\text { Martens. } \\
\text { Maund. } \\
\text { Mantissa. } \\
\text { Metten. } \\
\text { Meyer. } \\
\text { Michaux. } \\
\text { Moore. } \\
\text { Müller. } \\
\text { Newman. } \\
\text { Petirer. } \\
\text { Mlumier. } \\
\text { Pinder. } \\
\text { Plukenet. }\end{array}$ & $\begin{array}{l}\text { Poiret. } \\
\text { Presl. } \\
\text { Pursh. } \\
\text { Raddi. } \\
\text { Theed. } \\
\text { Retzius. } \\
\text { Reinmardt. } \\
\text { Roth. } \\
\text { Salisbury. } \\
\text { Schkuhr. } \\
\text { Schott. } \\
\text { Schlechtendal. } \\
\text { Siebold. } \\
\text { Sim. } \\
\text { Sieber. } \\
\text { Sloan. } \\
\text { Smith, J. E. } \\
\text { Smith, J. } \\
\text { Sprengel. } \\
\text { Spenner. } \\
\text { Stendal. } \\
\text { Sowerby. } \\
\text { Strempel. } \\
\text { Swartz. } \\
\text { Thompson. } \\
\text { Tenore. } \\
\text { Thnmberg. } \\
\text { Tuckerman. } \\
\text { Veitel, Jun. } \\
\text { Villars. } \\
\text { Van Houtte. } \\
\text { Vogler. } \\
\text { Wallich. } \\
\text { Weis. } \\
\text { Willdenow. } \\
\text { Wilson. } \\
\text { Wollaston. } \\
\text { Wolsey. } \\
\text { Timoli }\end{array}$ \\
\hline
\end{tabular}




\section{CONTRIBUTORS TO VOL. VI.}

THE Author begs to thank the following individuals, who have kindly supplied plants and fronds for illustration:-

Miss Barker, Trent Lock, Beeston, near Nottingham.

Messrs. Booth and Son, Nurserymen, Hamburg.

Mr. Clapham, Scarborough.

Mr. Clarke, Royal Botanic Gardens, Glasgow.

Mr. Robert Clarke, Gardener to W. Dent Esq., Flass House, Crosby Ravensworth, Westmoreland.

Mr. E. Cooling, Nurseryman, Derby. Mrs. Delves, Tunbridge Wells.

Mr. R. J. Gray, St. Thomas', Exeter. Messrs. A. Henderson and Co., Nurserymen, Pine-apple Place, Edgeware Road, London.

Messrs. E. G. Henderson, Wellington Nursery, St. John's Wood, London.

Mr. Joseph Henderson, Wentworth House, Yorkshire.

Mr. W. Ingram, Belvoir Castle, near Grantham.

Mr. J. W. Jeans, F.R.A.S., Grantham.

Captain Legard, Kirby Misperton, Yorkshire.

Mr. R. T. Millett, Penzance.

Captain A. S. H. Lowe, F.R A.S., Highfield House, near Nottingham.

Mr. Masters, Exotic Nursery, Canterbury.

Mr. Thomas Moore, F.L.S., Curator of the Chelsea Botanic Gardens.
Sir Oswald Mosley, Bart., Rolleston

Hall, near Burton-on-Trent.

Mr. G. Norman, Hull.

Mr. Pass, Gardener to T. BrockleHurst, Esq., The Fence, near Macclesfield.

Mr. J. Pearson, Nurseryman, Chilwell, Nottinghamshire.

Messrs. Rollisson and Co., Nursery, Tooting, near London.

II. Schott, Director of the Impcrial Garden, Schönbrunn, near Vienna. Mr. J. Smith, Curator of the Royal Gardens, Kew.

Mr. J. Sidebothan, Manchester.

Mr. R. Sim, Foot's Cray Nursery, near Chiselhurst, Kent.

Mr. Stansficld, Vale Nursery, Todmorden.

Mr. Stewart, Sudbury Castle, Staffordshire.

Mr. Stratton, Botanic Gardens, Cambridge.

Messrs. Veitch, Exotic Nursery, Exeter.

Messrs. Veitch, Jun., Exotic Nursery, Chelsea.

Mr. G. B. Wollaston, Chiselhurst, Kent.

Mr. Wraight, Newlands, Kent.

Mr. F. Wright, Osmaston Manor, Derbyshire. 
ADDENDUM TO VOL. VI.

Aspidium frondosum.-Rhizoma creeping on the surface. Stipes very long, stout, and nearly erect; base very scaly. Frond pentangular and quadri-tripinnate; length two to four feet. Frond borne gracefully and almost horizontally on its stalk. It will probably prove hardy. 
Date Due

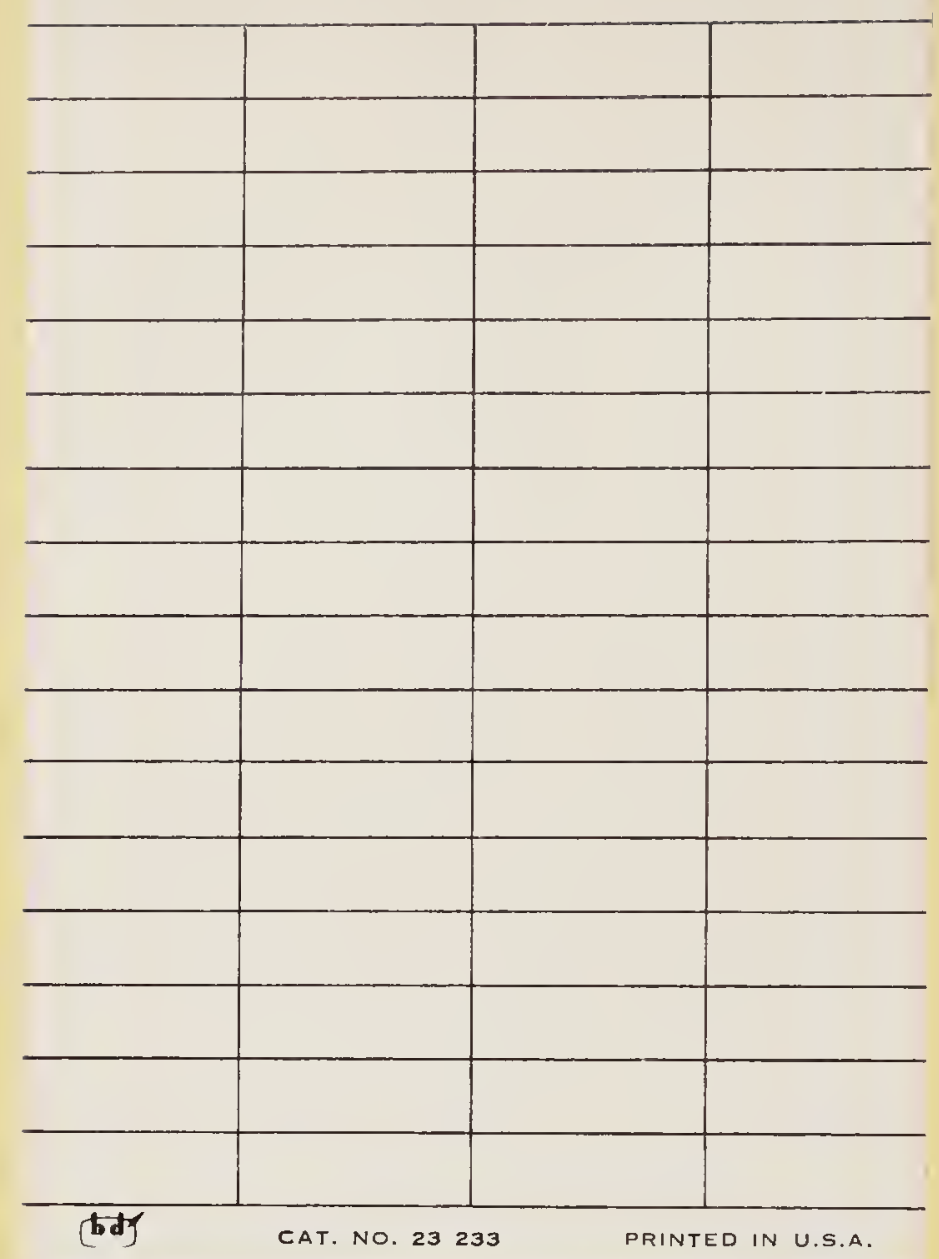




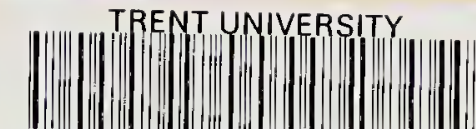 \\ 0116400216366}

$$
\text { QR523 .L9 v. } 6
$$

Lowe, Edward Joseph

Ferns: British and exotic.

$$
81785
$$

DATE

ISSUED TO

$$
21785
$$


